\title{
The Anatomy of an Alkalic Porphyry Cu-Au System: Geology and Alteration at Northparkes Mines, NSW, Australia
}

\author{
Adam Pacey $^{1,2, *}$, Jamie J. Wilkinson ${ }^{2,1}$, Jeneta Owens ${ }^{3}$, Darren Priest ${ }^{3}$, David R. Cooke ${ }^{4,5}$ and lan L. Millar ${ }^{6}$ \\ ${ }^{1}$ Department of Earth Science and Engineering, Imperial College London, South Kensington, London, SW7
} $2 A Z$, United Kingdom

${ }^{2}$ Department of Earth Sciences, Natural History Museum, Cromwell Road, London, SW7 5BD, United

Kingdom

${ }^{3}$ Northparkes Mines, PO Box 995, Parkes, New South Wales, 2870, Australia

${ }^{4}$ Centre for Ore Deposit and Earth Sciences (CODES), University of Tasmania, Hobart, Tasmania 7001, Australia

${ }^{5}$ Transforming the Mining Value Chain (TMVC), an Australia Research Council (ARC) Industrial Transformation Research Hub, University of Tasmania, Hobart, Tasmania 7001, Australia

${ }^{6}$ NERC Isotope Geosciences Laboratory, Keyworth, Nottingham, NG12 5GG, United Kingdom

*Corresponding author: adampacey@gmail.com

\section{Keywords}

Northparkes, Macquarie Arc, porphyry deposit, propylitic alteration, potassic alteration, hydrothermal alteration, copper, gold

\begin{abstract}
The Late Ordovician-Early Silurian ( $\sim 55-435 \mathrm{Ma}$ ) Northparkes system is a group of silica-saturated, alkalic porphyry deposits and prospects which developed within the Macquarie Island Arc. The system is host to a spectacular and diverse range of rocks and alteration-mineralization textures that facilitate a detailed understanding of its evolution, in particular into the nature and controls of porphyry-related propylitic alteration.
\end{abstract}

The first intrusive phase at Northparkes is a pre- to early-mineralization pluton that underlies all the deposits and varies in composition from a biotite quartz monzonite (BQM) to alkali feldspar granite (AFG). Prior to total crystallization, this pluton was intruded by a more primitive quartz monzonite (QMZ) that marks the onset of a fertile fractionation series. Towards its upper levels, the QMZ is porphyritic and locally rich in $\mathrm{Cu}$ sulfides. Subsequently, a complex series of syn-mineralization quartz monzonite porphyries (QMP) were emplaced. The QMP intrusions have a distinct pipe-like morphology and are ubiquitously Kfeldspar altered with a crystal-crowded porphyritic texture. The textures of the QMPs and common occurrence of porphyry-cemented contact breccias indicate they were forcibly emplaced and of relatively 
low viscosity. The QMPs are therefore interpreted as crystal-bearing, silicate melt-aqueous fluid slurries that represent the conduits through which deep-seated magmatic-derived ore fluid was discharged into the shallow crust (1-2 km depth).

Each deposit is centred on a multiphase cluster of QMP intrusions that drove discrete hydrothermal systems. Initial fluid evolution was similar in all the deposits, with three major alteration facies developed as largely concentric zones around the QMP complexes. The innermost zone is host to Cu sulfide ore and dominated by K-feldspar alteration. This transitions outwards through a shell of magnetite \pm biotite alteration, with pyrite and minor chalcopyrite, to an outer halo of propylitic alteration. Generally, epidote, chlorite and pyrite are abundant in the most deposit-proximal propylitic zone, with a decrease in the abundance of pyrite, and then epidote, with increasing distance away from deposit centers.

Propylitic alteration, particularly within relatively low permeability rocks, is fracture-controlled and a hierarchy of veins is observed. Veins of chlorite-quartz-pyrite \pm calcite \pm hematite \pm epidote \pm chalcopyrite (P1) appear to represent the principal fluid conduits. They are surrounded by pervasive and intense alteration halos with a distinct mineralogical zonation from vein-proximal chlorite-sericite (phengite) \pm epidote \pm pyrite, through hematite-sericite-chlorite \pm epidote, ultimately to a vein-distal hematite-albite \pm chlorite \pm epidote assemblage. These P1 veins are surrounded by regions in which smaller epidote-chlorite \pm calcite \pm quartz \pm pyrite veins $(\mathrm{P} 2)$ are abundant, again with zoned alteration envelopes: vein-proximal chlorite-sericite (phengite) \pm epidote \pm pyrite grades out into an epidote-rich zone, which in turn transitions into vein-distal albite-hematite \pm chlorite \pm epidote. Areas of weakest propylitic alteration, distant from both P1 and P2 veins, are characterised by small epidote-only veinlets (P3) with albite-hematite halos. Mineralogical transitions across the propylitic zone are therefore repeated in the evolution from P1 to P3 veins, as well as in the halos around these veins. It is the overall vein abundance and overlap of associated alteration halos which controls the intensity and appearance of propylitic alteration in most rocks. Such scale-invariance and spatial relationships strongly suggests the transition from P1 to P3 veins reflects a broadly decreasing outward flux of (magmatic-derived?) fluid that passed through the fracture network and progressively reacted with country rocks. Further support for this hypothesis comes from cross cutting relationships and $\mathrm{Rb}$-Sr dating of epidote (returning an age of $450 \pm 11 \mathrm{Ma}$ ), which demonstrate the bulk of propylitic alteration was coeval with mineralization and potassic alteration.

Late-stage fluid evolution at each deposit was unique. Much of the E48 orebody and locally the GRP314 deposit was overprinted by texturally-destructive, white sericite-albite-quartz-alunite \pm chlorite alteration. In the E26 deposit, and in regions of the GRP314 deposit, a series of quartz-anhydrite \pm pyrite \pm Cu sulfide veins with distinctive, vein-proximal, sericite-dominant alteration halos cut the primary, deposit-concentric alteration facies. The vein-distal mineralogy of these alteration halos is controlled by their distance from deposit centers, changing from K-feldspar \pm biotite in deposit-proximal veins to chlorite \pm epidote-albite in deposit-distal veins. Late-mineralization QMPs at E26 and GRP314 also appear to be related to the 
generation of anhydrite-quartz \pm sphalerite veins and a set of quartz-calcite-pyrite-sphalerite \pm chalcopyrite \pm galena veins. Post-mineralization magmatic activity produced relatively primitive and barren monzonite porphyries and younger alkali basalt dikes.

\section{Introduction}

Mining at Northparkes exploits a cluster of Late Ordovician-Early Silurian, silica-saturated, alkalic porphyry Cu-Au ore deposits, located 27 km northwest of Parkes, in central-west New South Wales, Australia (Fig. 1). The region consists largely of flat agricultural land, with extensive cover of Mesozoic to Quaternary sediments. All the Northparkes orebodies are blind at the surface and, consequently, the first discovery was not made until 1976, when exploratory drilling encountered the Endeavour (E) 22 deposit (Jones, 1985). Subsequent exploration defined the E27, E26, E48 deposits and, most recently, a new, yet-to-be-exploited resource named after the discovery drillhole: GRP314.

Mineralization is focused within and around a series of multiphase quartz monzonite porphyry intrusions which appear to terminate below the surface (Fig. 2) and show a remarkable pipe-like geometry, typically only $\sim 50-100 \mathrm{~m}$ in diameter but extending to depths of $>1 \mathrm{~km}$. Copper sulfides are disseminated throughout K-feldspar and quartz vein stockworks in areas of potassic alteration which surround the margins and apices of the mineralizing porphyry bodies. The resulting ore zones are vertically continuous, elliptical prisms, several hundreds of meters in diameter. These were accessed historically by open pits at E22, E26 and E27, and presently via block caving at E26 and E48. As of 2017, the total remaining ore reserve at Northparkes was $126 \mathrm{Mt}$ at $0.57 \% \mathrm{Cu}$ and $0.20 \mathrm{~g} / \mathrm{t} \mathrm{Au}$, with a measured, indicated and inferred resource of $472 \mathrm{Mt}$ at $0.56 \% \mathrm{Cu}$ and $0.19 \mathrm{~g} / \mathrm{t}$ Au (China Molybdenum Co., Ltd., 2018). Historic production, as of December 2016, was 0.9 Mt Cu and 1.7 Moz Au (Owens et al., 2017). The total known endowment of Northparkes is, therefore, approximately 3.5 Mt Cu and 4.4 Moz Au.

Initial reviews of mineralization in the Northparkes district were provided by Jones (1985) and Heithersay et al. (1990), with later contributions dedicated to descriptions of deposit-specific geology at E26 (House, 1994; Heithersay and Walshe, 1995; Harris, 1997), E27 (Squires, 1992) and E48 (Wolfe, 1994; Hooper et al., 1996). This culminated in the work of Lickfold et al. $(2002,2003,2007)$ who investigated the geochemistry and intrusive history of the Endeavour porphyries (E22, E26, E27 and E48). Subsequently, the geology of GRP314 was outlined by Hendrawan (2011a) and Johnson (2011); Hendrawan (2011b) also re-examined geology and alteration at the E48 deposit. Additional, more targeted research focused on the origin of sericitic alteration at E26 and E48 (Wolfe, 1996; Harris and Golding, 2002), base metal veins near the E28 prospect (Kolkert, 1998), copper isotope zonation around E26 and E48 (Li et al., 2010), and vein emplacement mechanisms at E26 (Harris and Holcombe, 2014).

These studies have resulted in the definition of numerous intrusive phases, alteration facies and vein types in the ore zones, whereas comparatively little attention has been paid to the more distal portions of the systems. This is particularly true for the propylitic alteration footprint which has only been previously 
considered in a small pilot study (Radclyffe, 1995), but is by far the most widespread, covering an area some 20x greater than the potassic alteration domain and dominating in the mine lease. Further, in the decades following most work on the Endeavour deposits, several hundred kilometers of diamond drilling have been completed, both improving the 3D understanding of the systems and resulting in the discovery of new intrusive phases and mineralized centers. These new data provide a timely opportunity to revise and update our understanding of this classic alkalic porphyry district.

The aims of this paper are to: (i) provide an up-to-date review of the regional geology, principal lithologies and igneous geochemistry, including the interpretation of 232 new whole rock analyses, in order to characterise the Northparkes host units and their evolution; and (ii) present in this context the results of detailed logging and observations that describe vein types and alteration in the system with a focus on the peripheral propylitic altered domains surrounding the E26 and E48 deposits. The latter is, to our knowledge, the most detailed description of propylitic alteration in any porphyry district published to date. The observations and temporal relationships interpreted here underpin a new model for propylitic alteration in porphyry systems to be published in forthcoming contributions. Such understanding is important given the increasing use of propylitic mineral chemistry in exploring for buried porphyry deposits.

\section{Regional geology}

The Northparkes deposits occur within the Junee-Narromine volcanic belt, one of four such belts within the eastern Lachlan Orogen of New South Wales (Fig. 1). Together, these constitute the Early Ordovician to earliest Silurian Macquarie Arc, comprising largely high-K, calc-alkaline to shoshonitic volcanic-volcaniclastic sequences, with some intercalated Middle to Late Ordovician carbonates (e.g., Crawford et al., 2007; Glen et al., 2012). As implied in the name, the Macquarie Arc is generally thought to represent the accreted suprasubduction zone remains of an intra-oceanic arc developed outboard of Gondwana (e.g. Glen et al., 1998; 2007; 2012; Cooke et al., 2007). In the Parkes region, the Junee-Narromine Volcanic Belt is composed of three principal stratigraphic packages (Krynen et al., 1990). These units and structural features of the area are described below with reference to the geological map (Fig. 3).

\section{The Nelungaloo Volcanics and Yarrimbah Formation}

The Lower Ordovician Nelungaloo Volcanics are the oldest exposed rocks of the Junee-Narromine Volcanic Belt. They consist largely of high-K, calc-alkaline andesites to basaltic andesites and volcaniclastic rocks (Glen et al., 2007), with a combined estimated thickness of $1.5 \mathrm{~km}$ (Simpson et al., 2005). The minimum age of this package is constrained by intrusions of broadly comagmatic monzodiorite bodies, which provided a zircon U-Pb (SHRIMP) age of $481 \pm 4$ Ma (Simpson et al., 2005 after Butera et al., 2001).

The Yarrimbah Formation directly overlies the Nelungaloo Volcanics (Sherwin, 1979, 2000). It is described by Glen et al. (2007) as a 400-600 m-thick, broadly fining upwards sequence of volcaniclastic sandstones, 
siltstones and bedded mudstones deposited, based on fossil dating, between the Lancefieldian ( $479 \mathrm{Ma}$ ) and Bendigonian ( $476 \mathrm{Ma}$; Sherwin, 1979).

\section{The Goonumbla Volcanics - Billabong Creek Limestone and Gunningbland Formation}

The Middle to Late Ordovician Goonumbla Volcanics are separated from the underlying Nelungaloo Volcanics by an inferred low angle unconformity, representing a depositional hiatus of 10 Myr (Krynen et al., 1990; Percival and Glen, 2007). Trachyandesites are the dominant lithology along with lesser basaltic andesites, volcaniclastic conglomerates and rare limestones, giving a total thickness of 2.5-4 km. Many of the massive trachyandesites have peperitic upper and lower contacts, suggesting they represent shallowlyemplaced sills (Kolkert, 1998; Simpson et al., 2005; this study). A second generation of monzodiorite bodies intruded the base of the Goonumbla Volcanics near Goonumbla, with a zircon U-Pb (SHRIMP) age of 450.8 $\pm 4.2 \mathrm{Ma}$ (Butera et al., 2001), providing a minimum age constraint on the volcanic sequence. However, as this monzodiorite does not appear to directly intrude the trachyandesite sills (Simpson et al., 2005), the sills could still be younger.

Around Gunningbland (Fig. 3), the shallow marine Billabong Creek Limestones and overlying deeper water Gunningbland Formation are intercalated with, and occur as lateral equivalents of, the Goonumbla Volcanics (Percival and Glen, 2007). The Billabong Creek Limestones and Gunningbland Formation have a maximum thickness of $\sim 1.1 \mathrm{~km}$ and were dated by Pickett and Percival (2001) using a near continuous fossil record. Results indicated deposition between the Darriwilian ( $\sim 65 \mathrm{Ma}$ ) and Eastonian ( $452 \mathrm{Ma}$ ).

\section{The Wombin Volcanics}

The $>3 \mathrm{~km}$ thick Wombin Volcanics directly overlie the Goonumbla Volcanics, although it remains unclear if there was a hiatus between their deposition. Together, these sequences comprise the Northparkes Group (Percival and Glen, 2007). Krynen et al. (1990) defined the Wombin Volcanics based on their more evolved chemistry and reddish-brown coloration. They are dominated by volcanic breccias and sandstones along with trachytes, ignimbrites and a series of trachyandesite sills, similar to those identified in the Goonumbla Volcanics (Simpson et al., 2005).

The age of the Wombin Volcanics is poorly constrained to the Late Ordovician or earliest Silurian. They must post-date the latest Eastonian age Goonumbla Volcanics ( $450 \mathrm{Ma}$; Webby et al., 2004), and minimum constraints are imposed by several monzonite intrusions emplaced throughout the area. A monzonite body near Cooks Myalls returned a zircon U-Pb (SHRIMP) date of $439 \pm 5$ Ma (Butera et al., 2001) and Lickfold et al. (2007) reported a further zircon U-Pb (SHRIMP) date of $444.2 \pm 4.7 \mathrm{Ma}$ for the biotite quartz monzonite (BQM) at Northparkes.

\section{Structural geology and regional metamorphism}

Rocks within the Lachlan Fold Belt have experienced a protracted deformation history during continental accretion, with at least six individual orogenic events defined (Gray et al., 1997). However, based on a 
compilation of ${ }^{40} \mathrm{Ar} /{ }^{39} \mathrm{Ar}$ slate whole rock and white mica crystallization ages, Gray and Foster (2004) suggested most deformation in the Parkes region occurred between 410 and $380 \mathrm{Ma}$.

In the Parkes district, strain is strongly partitioned into thrust faults and less competent units. For example, highly deformed and foliated deep marine sediments occur east of the Parkes Thrust (Fig. 3) in contrast to only gently folded and non-foliated volcanic rocks to the west. Ductile strain in volcanic rocks is limited to the NNE-striking, gently plunging and open-hinged Forbes Anticline and Milpose Syncline. These folds are cut by a conjugate set of ESE-striking sinistral and SSE-striking dextral faults, exemplified by the Dalveen Fault Zone. Regional mapping (e.g., Heithersay et al., 1990; Krynen et al., 1990; Arundell, 1997; Simpson et al., 2005) has shown that rocks of the largely Lower Devonian Trundle Group (Sherwin, 1996), which unconformably overlies the Wombin Volcanics, are unaffected by the Dalveen Fault. Faults related to the Dalveen Fault Zone have offset the Parkes Thrust (Fig. 3). These observations appear to constrain deformation to the Middle Silurian to Lower Devonian, at the oldest end of the estimate provided by Gray and Foster (2004).

Regional metamorphism of volcanic rocks in the Parkes area appears to be limited to prehnite-pumpellyite facies, with the widespread development of chlorite, calcite, prehnite, pumpellyite and quartz. Minor epidote, albite and zeolites are also observed, making the distinction between metamorphic and porphyrypropylitic assemblages potentially problematic. However, there is no evidence to suggest a resolvable metamorphic overprint of the Northparkes deposits, with all alteration assemblages appearing to be hydrothermal in origin.

\section{The Northparkes deposits}

The Northparkes deposits are a cluster of five Cu-Au ore zones: Endeavour (E) 22, 26, 27, 48 and GRP314, all of which occur in an area of only $\sim 10 \mathrm{~km}^{2}$ (Figs. 4-6). The deposits are hosted within both the Goonumbla and Wombin Volcanics, with mineralization-related intrusive rocks effectively forming part of the latter.

\section{General features}

Mineralization comprises disseminated $\mathrm{Cu}$ sulfides and fracture coatings within quartz vein stockworks and zones of potassic alteration, both of which are spatially and temporally associated with multiphase quartz monzonite porphyry (QMP) complexes. Bornite is the dominant sulfide in the center of these magmatichydrothermal systems, transitioning outwards to a chalcopyrite-rich shell and pyrite-dominant periphery. Highest $\mathrm{Au}$ grades are in the core of the systems, where $\mathrm{Au}$ is present largely as fine, native inclusions in both silicates and bornite, and occurs with minor tellurides (Müller et al., 1994; Lickfold, 2002). Oxidation extends to $\sim 80 \mathrm{~m}$ below surface in the region. Consequently, the highest-level deposits, E22, E26 and E27, exhibit thin, but well-developed oxide ore zones (Crane et al., 1998; McLean et al., 2004). These comprise an uppermost zone of $\mathrm{Cu}$ phosphates, notably including sampleite and libethenite at E26, passing down 
through a layer of $\mathrm{Cu}$ carbonates to a small supergene enrichment horizon with native $\mathrm{Cu}$, cuprite and chalcocite (Clissold et al., 2005).

The QMP bodies form part of a series of silica-saturated alkaline intrusions that dominate in the mine area. The most voluminous phase is a pre- to early-mineralization pluton, variable in composition between a biotite quartz monzonite (BQM) and alkali feldspar granite (AFG). It underlies and partly hosts mineralization. QMP complexes at E22, E26, E27 and E48 were emplaced on the shoulders, and GRP314 within the center, of apophyses of this pluton (Figs. 4-6).

Rocks of the Goonumbla Volcanics are the principal host to the E22, E26, E27 and E48 deposits, although the upper parts of the BQM-AFG pluton and mineralized porphyries also intruded the overlying Wombin Volcanics. In contrast, GRP314 is hosted entirely within intrusive rocks, comprising QMP bodies contained within a larger, weakly-mineralized quartz monzonite phase, which is itself enclosed by the BQM-AFG pluton (Fig. 4).

\section{Structural features}

A distinctive feature of most of the mineralized porphyry intrusions is their elongate, pipe-like geometry ('pencil porphyries'), being typically 50-100 $\mathrm{m}$ in diameter and $>1 \mathrm{~km}$ in vertical extent (e.g., Figs. 5 and 6). However, some porphyry intrusions also occur as dikes. At GRP314 drilling appears to show dikes with a NESW trend and of similar orientation are a series of thin, post mineralization, alkali basalt dikes which occur throughout Northparkes. In contrast, a distinctive post-mineralization monzonite porphyry phase, known as the zero porphyry, occurs exclusively as NW-SE-striking dikes, which cut through the center of E26, are common at E37 and are further recorded near E34 (this study; Fig. 4). Using orientated core measurements, Harris (1997) demonstrated that stockwork veins in all the Endeavour deposits show a similar strike ( 140$170^{\circ}$ ). Harris and Holcombe (2014) further investigated the complex nature of vein orientations at the E26 deposit, once again revealing a preferred NNW-SSE trend. Consequently, it has been suggested that the pipe-like morphology of the mineralizing bodies perhaps reflects emplacement at the intersections of these fault-fracture sets (Harris, 1997; Crawford, 2001).

The Wombin and Goonumbla Volcanics at Northparkes are slightly tilted, with a broad SE dip of $\sim 10-20^{\circ}$ between E48 and E26. Porphyry bodies are subvertical, indicating that tilting occurred pre-mineralization. Post-mineralization deformation is remarkably limited: this may be partly owing to the underlying plutonic monzonite, effectively forming a strain-resistant crustal block (Scheibner, 1993).

The most significant post-mineralization structural feature, the Altona Fault (Figs. 3, 5 and 6), has no surface outcrop, but is known from extensive drilling to be a large, shallowly $\left(\sim 15^{\circ}\right)$ east-dipping planar structure. Displacement on this fault poses significant exploration challenges. The E28 prospect is the very top of another porphyry Cu-Au deposit located entirely within the hanging wall of the Altona Fault (Jones, 1985; Kolkert, 1998). The top of E48 and an upper section of the GRP314 system are both located in the 
footwall and are truncated by the fault. GRP314 was only discovered in 2004 during underground and subsequent surface drilling to explore below the structure (Lye, 2006). Although the sense of displacement has been debated, investigations based on drill core structures suggest the Altona Fault is a top-to-the-west thrust, with an offset of several hundreds of meters (Dalstra and Oosterwijk, 2005).

\section{Geochronology}

Radiometric dating studies at Northparkes have been relatively limited in number (Fig. 7). The age of mineralization was first estimated as 439.2 $\pm 1.2 \mathrm{Ma}$ by Ar/Ar dating of sericite at the E26 deposit (Perkins et al., 1990). Subsequently, Lickfold et al. (2003) provided biotite $\operatorname{Ar} / \operatorname{Ar}$ age estimates for the BQM (437.3 \pm $2.1 \mathrm{Ma})$, alteration at E26 (441.3 $\pm 3.8 \mathrm{Ma})$, and biotite-rich QMP intrusions at both E26 (448.6 $\pm 7.0 \mathrm{Ma})$ and E22 (446.5 $\pm 2.6 \mathrm{Ma})$. However, interpretation of these results is difficult, as the closure temperature for $\mathrm{Ar}$ in biotite is $\sim 300^{\circ} \mathrm{C}$ and is variable both as a function of Fe-Mg content and cooling rate (e.g., Harrison et al., 1985). Therefore, at best, such dates reflect the point in time when samples cooled permanently below this threshold, and thus provide minimum age constraints. Lickfold et al. (2007) reported two further age estimates based on U-Pb (SHRIMP) dating of zircon from the BQM at E26 (444.2 \pm $4.7 \mathrm{Ma})$, and from the zero monzonite porphyry near the E37 prospect (436.7 $\pm 3.3 \mathrm{Ma}$ ). These intrusions, and therefore dates, effectively bracket the period of mineralization.

As part of this study, $\mathrm{Rb}-\mathrm{Sr}$ dating of fourteen epidote separates and ten whole rock samples, collected from around the E48 deposit, provided an estimate of $450 \pm 11$ Ma for associated propylitic alteration (Fig. 8; Appendix A). Although not a precise isochron (which would require MSWD $\leq 2$ ), this relationship supports a limited time interval between volcanism, emplacement of plutonic rocks and hydrothermal activity within the propylitic alteration zone.

Currently available radiometric age constraints cannot, in isolation, establish the relative order of magmatic-hydrothermal events at Northparkes. They do, however, strongly suggest that most activity occurred in the latest Ordovician to earliest Silurian and demonstrate a temporal relationship between such activity and formation of the Wombin Volcanics.

\section{Principal lithologies}

Key lithological units at Northparkes are summarized below, and their typical occurrence is illustrated in Figure 9. Descriptions are based mainly on drill core logging at E26 and E48 but are supplemented where indicated by published literature and Northparkes Mines reports.

\section{Country rock volcanics}

\section{Trachyandesites}

Basaltic trachyandesites to trachyandesites form a significant proportion of the Goonumbla Volcanics and are also found within the Wombin Volcanics. They are dark brown to black and ubiquitously porphyritic, comprising $20-50 \%$ of $1-4 \mathrm{~mm}$ plagioclase laths and minor pyroxene in a very fine to aphanitic groundmass 
(Fig. 10a). Peperitic textures and hyaloclastic breccias (Fig. 10b) record magma-wet sediment interaction between trachyandesite units and volcaniclastic rocks in both the Goonumbla and Wombin Volcanics. Such textures occasionally allow the distinction between intrusive and extrusive units to be made, although this is often ambiguous in altered drill-core. Regardless, they attest to the water-saturated and poorlyconsolidated nature of the volcanic stratigraphy during this phase of magmatism.

\section{Volcanic conglomerates}

Massive packages of polymict, matrix-supported conglomerates, fining upwards into volcanic sandstones, are present in the Goonumbla Volcanics. These comprise clasts of trachyandesite, sandstone and siltstone in a silt and mud matrix. Trachyte clasts are also present in matrix-supported conglomerates within the Wombin Volcanics.

\section{Volcanic sandstones, siltstones and mudstones}

Most volcanic sandstones comprise massive, fine to medium grained and moderately- to very well-sorted units composed of lithic fragments and rarer abraded crystals set in a fine silt to mud matrix. Internal bedding and lamination are relatively rare. Siltstones and mudstones are uncommon, but may show wet sediment deformation structures, including load casts, flame structures and minor slump folds (Fig. 10c).

\section{Trachytes}

Thin $(<1-10 \mathrm{~s} \mathrm{~m})$ units of pink- to brick-red-colored trachyte occur within the Wombin Volcanics. These are typically aphanitic or finely porphyritic, with sparse, 1-3 mm euhedral plagioclase and rare K-feldspar, pyroxene, biotite and hornblende phenocrysts in an aphanitic K-feldspar-quartz groundmass.

\section{Trachytic volcanic breccia (ignimbrite)}

Trachytic volcanic breccias are restricted to the Wombin Volcanics and are inferred to be welded, lithiccrystal ignimbrites. They contain angular to sub-angular clasts of trachyte, trachyandesite and volcaniclastic rocks along with 10-30\% euhedral and broken plagioclase, K-feldspar and pyroxene crystals. These are set in a welded, irregularly-banded aphanitic matrix with wispy patches of crystal-poor material, interpreted by Simpson et al. (2005) as pumice fragments (Fig. 10d).

\section{Northparkes intrusive rocks}

\section{Monzodiorite}

An equigranular, pre-mineralization monzodiorite is rarely observed as xenoliths within the BQM pluton (Fig. 11a). It consists 10-30\% mafic minerals, most commonly augite and biotite, with lesser magnetite and hornblende, intergrown with 60-70\% plagioclase and minor alkali feldspar ( 10\%).

\section{Biotite quartz monzonite (BQM)}

The BQM comprises a large intrusion in the Northparkes area, revealed by the $\sim 12 \mathrm{~km}$ diameter negative Bouguer gravity anomaly (Fig. 3). The rock exhibits a continuously variable texture from coarse and equigranular, through to medium grained and porphyritic. The equigranular end-member comprises 
interlocking, 2-4 mm euhedral plagioclase and K-feldspar crystals with $10-20 \%$ subhedral biotite; quartz is present as an anhedral interstitial phase ( $5 \%)$ with further K-feldspar (Fig. 11b). In the porphyritic endmember, euhedral 3-5 mm plagioclase phenocrysts dominate (40-60\%), along with subhedral biotite ( $10 \%)$ within a finer-grained (but still visibly crystalline) interstitial mass of interlocking K-feldspar and quartz (Fig. 11C). Minor specks of chalcopyrite and bornite are present within the BQM, and patches of chalcopyrite occur in rare pegmatitic segregations.

\section{Alkali feldspar granite (AFG)}

The AFG (Fig. 11d) occurs as another distinct and voluminous lithology within the BQM-dominated pluton. It appears to be a later differentiate of the BQM: contacts between the two are either gradational over tens of meters, or distinct but irregular, with plagioclase phenocrysts observed to pass over the contact. The AFG is coarse and relatively equigranular, typically consisting of 10-30\% euhedral, 2-4 mm plagioclase crystals (commonly amalgamated together) surrounded by only slightly finer, interlocking K-feldspar and quartz. Quartz is present locally as $1-2 \mathrm{~mm}$ anhedral grains, the varying abundance of which shifts the composition between an alkali feldspar syenite and alkali feldspar granite. Biotite is restricted to $1-5 \%$.

\section{Quartz monzonite (QMZ)}

A large, NE-SW-trending QMZ body occurs within the BQM-AFG pluton at GRP314 and at depth around E26 and E48. Contacts with the pluton may be sharp or gradational over tens of meters. Sub-rounded BQM xenoliths are common within the QMZ. Textures vary between strongly porphyritic (Fig. 11e), with a fineaphanitic groundmass, through to weakly porphyritic with a visibly crystalline groundmass. Phenocrysts typically range from $0.5 \mathrm{~mm}$ to $3 \mathrm{~mm}$ and comprise 5-10\% anhedral quartz, 30-70\% characteristically subhedral to anhedral plagioclase and $10-40 \%$ euhedral to subhedral K-feldspar with minor biotite (1-5\%). In rare instances, K-feldspar forms larger phenocrysts $(1-3 \mathrm{~cm}$; Fig. 11f) that may overgrow anhedral plagioclase. Quartz-aplite unidirectional solidification textures (USTs) are sometimes observed and $\mathrm{Cu}$ sulfides may be present.

\section{Quartz monzonite porphyries (QMP)}

All major orebodies at Northparkes are spatially associated with small-volume QMP intrusions (Fig. 12a-d) that occur as pipe-like to occasionally more elongate, dike-like bodies (Figs. 5 and 6). Multiple magmatic pulses are recognizable, each of which are variably altered and may exhibit dramatic spatial variability in their size, shape, groundmass granularity and phenocryst abundance (40-90\%).

K-feldspar phenocrysts are typically large (1-2 cm), euhedral and commonly zoned (Fig. 12c, d) but are also observed as angular broken fragments (Fig. 12a, b). Plagioclase phenocrysts are generally smaller $(<1 \mathrm{~cm})$, subhedral crystals that are locally overgrown by K-feldspar (Fig. 12c). The groundmass varies from aphanitic to finely crystalline and is largely composed of quartz and K-feldspar. Biotite, augite and hornblende may be 
present as mafic phenocrysts and accessory apatite, titanite and zircon have been recorded (Lickfold, 2002).

Lickfold et al. (2003) petrographically distinguished three sub-types of QMP: (1) K-feldspar QMP - with <2\% mafic phenocrysts (Fig. 12a); (2) augite-K-Feldspar QMP - with 2-5\% mafic phenocrysts, largely of augite and biotite (Fig. 12b); and (3) biotite QMP - with 5-10\% mafic phenocrysts, largely of biotite (Fig. 12c). Generally, the K-feldspar QMP bodies are most closely associated with mineralization. However, there is no consistent temporal relationship between these sub-types and practical application of this classification is challenging. Consequently, QMP intrusions are grouped by Northparkes Mines based on their relative timing and spatial association with mineralization (e.g. Figs. 4-6).

\section{Monzonite porphyries}

A distinct, crystal-crowded, post-mineralization monzonite porphyry (Fig. 12e) occurs as SE-striking dikes that cut through the E26 deposit. This phase is frequently referred to as the 'zero' porphyry, due to its low $\mathrm{Cu}-\mathrm{Au}$ concentrations ( $<10 \mathrm{ppm} \mathrm{Cu},<1 \mathrm{ppm} \mathrm{Au}$ ) which result in local grade dilution. Only weak propylitic alteration and hematite reddening have affected the zero porphyry. It is typically brownish red, with phenocrysts comprising 5-15\% mafic minerals (augite, biotite and magnetite), 60-70\% plagioclase and 1020\% K-feldspar within an aphanitic K-feldspar groundmass. Lickfold (2002) also reported the occurrence of primary anhydrite phenocrysts. As with the QMP intrusions, plagioclase and K-feldspar phenocrysts may be zoned and either euhedral or fragmental. Along some dike margins and sometimes occurring as highly irregular shaped xenoliths in the zero porphyry (Fig. 12f) is a dark brown, plagioclase-phyric basaltic trachyandesite (the 'mafic zero'). This appears to represent commingling of two magmatic phases, with the zero porphyry emplaced into the same structure as the earlier, mafic zero, before it had totally solidified (Keith et al., 1998; Lickfold et al., 2007).

A monzonite porphyry body that is located near the E34 prospect also appears to be post-mineralization. It cuts chlorite-quartz-epidote-albite (P1) veins in intensely propylitically-altered rocks. Xenoliths of these veins, pervasively epidote-altered country rock, sericitic (quartz-sericite-pyrite) veins and BQM are also observed. The intrusion comprises $\sim 40 \%$ phenocrysts, dominantly $<2 \mathrm{~mm}$ subhedral plagioclase feldspar with lesser biotite and typically larger $(1 \mathrm{~mm}-1 \mathrm{~cm})$ euhedral K-feldspar, set in an aphanitic K-feldspar groundmass (Fig. 12g). Porphyry-cemented breccias occur at the margins.

\section{Basaltic dikes}

Thin (30 cm to $1.5 \mathrm{~m}$ ), broadly NE-striking, post-mineralization dikes of alkali basalt have been documented at E22 and E27 (Jones, 1985; Lickfold et al., 2003), E48 (Wolfe, 1994; Hooper et al., 1996), E34 (this study) and GRP314 (Hendrawan, 2011a). Although most are unaltered, some dikes are pervasively overprinted by strong sericitic alteration. Alkali basalt has also been emplaced along the Altona Fault (Hooper et al., 1996). 


\section{Breccias and magmatic-hydrothermal features}

\section{Porphyry-hydrothermal phenomena}

K-feldspar-rich, syn-mineralization QMP bodies in all the deposits may contain highly irregular segregations of quartz-K-feldspar-sulfide \pm anhydrite \pm fluorite intergrown with aplite (Fig. 13a). In some instances, these patches appear layered and exhibit unidirectional, comb-quartz growth (Fig. 13b). Similar, irregular segregations of quartz-magnetite-chalcopyrite, as well as anhydrite-quartz \pm biotite (Fig. 13c) are also observed, notably at E26.

Vein dikes $(<1-5 \mathrm{~cm}$ wide) are common and are spatially associated with QMP. First described at E26, they consist of either quartz veins with a central aplitic fill, or a predominantly aplitic fill with coarse segregations and central intergrowths of hydrothermal quartz-K-feldspar-sulfide (Heithersay and Walshe, 1995).

\section{Pebble dikes}

Pebble dikes, typically $1 \mathrm{~cm}$ to $1 \mathrm{~m}$ wide, are post-mineralization, polymict hydrothermal breccia dikes that occur within all the known deposits (e.g., Jones, 1985; Heithersay et al., 1990; Lickfold, 2002; this study). Clasts do not necessarily reflect immediately adjacent wall rocks and comprise sub-angular to well-rounded fragments of all volcanic and intrusive lithologies, except for basaltic dikes, in a fine, dark rock flour matrix, together with some hydrothermal quartz-carbonate-pyrite cement (Fig. 13d). Clasts may be mineralized and/or show pervasive potassic, sericitic or propylitic alteration, and locally contain truncated veins.

\section{Porphyry-cemented breccias}

Porphyry-cemented breccias are relatively common in all the QMP complexes at Northparkes. At E27, the margins of syn- to late-mineralization QMP bodies are characterized by large zones of jigsaw-fit intrusion breccias in which angular clasts of mineralized host rock are cemented by plagioclase-phyric aplitic porphyry. This aplitic cement has commonly penetrated $<1 \mathrm{~mm}$ wide fractures and is typically intergrown with coarse segregations (examples up to several $\mathrm{cm}$ long) of hydrothermal quartz-K-feldspar-bornite (Fig. 13e).

Early open-pit operations at E27 also recovered large blocks (up to several meters long) of matrixsupported hydrothermal breccia with a cement of grey 'greasy' quartz and massive bornite (Fig. 13f). Euhedral K-feldspar crystals reaching $6 \mathrm{~mm}$ in length are contained within the bornite (Fig. 13g) and clasts are strongly potassically-altered.

At E34, a post-mineralization monzonite porphyry (Fig. 12g) exhibits brecciated contacts. With increasing distance from the intrusion, these grade from a porphyry-cemented breccia (Fig. 13h) into an extensive zone of brecciated country rock fragments, with irregular patches of porphyry locally surrounded by intensely chloritized rock flour (Fig. 13i). These rock flour breccias (Fig. 13j) are very similar in texture to the pebble dikes observed elsewhere (c.f. Fig. $13 \mathrm{~d}$ and $13 \mathrm{j}$ ). It is possible, therefore, that the sequence logged 
at E34 records the generation of pebble dikes at the point of explosive interaction between late porphyry intrusions and water-saturated country rocks.

\section{Pegmatites}

Pegmatitic dikes $(<4 \mathrm{~m}$ ), intersected at the base of GRP314, contain large (several $\mathrm{cm}$ long) interlocking crystals of K-feldspar and anhydrite, with accessory bornite, chalcopyrite, magnetite, biotite, muscovite and actinolite (Hendrawan, 2011a).

\section{Bornite clots}

Unusual, irregular 2-40 cm diameter 'clots' of massive bornite, with accessory chalcopyrite, K-feldspar and quartz occur in the QMP and QMZ intrusions, particularly at E22, E27 and GRP314 (Fig. 13k). In some cases, veins of pure bornite appear to emanate from large clots (Fig. 8e of Lickfold et al., 2003).

\section{Lithogeochemistry}

Whole rock geochemical analyses were conducted on 204 samples collected from logged diamond drill core. Data for a further 28 samples were provided by Rio Tinto and are here combined with the analyses of Johnson (2011), Lickfold (2002), Crawford et al. (2001), Blevin and Morrison (1997), Radclyffe (1995), Müller et al. (1994), Wolfe (1994), Hall (1993), Heithersay (1991) and Clarke (1990). Analytical details and the resulting data for 540 samples are provided in Appendix B.

In this paper, to best represent fresh rocks, we exclude all samples identified as strongly-altered based on original descriptions (where provided) and/or those which plot upon alteration trajectories within the feldspar K-Na general element ratio control diagram (Stanley and Madeisky, 1996). The only exceptions are data for five samples of potassically-altered QMP, six samples of moderately sericitically-altered monzonite porphyry (zero and mafic zero) and two samples of mafic dikes, which are retained to ensure adequate representation of these relatively rare phases within the dataset. The final 73 excluded analyses are indicated in Appendix B. Nevertheless, most remaining samples are altered to a minor extent, so that results for potentially mobile minor and trace elements must be treated with caution. Furthermore, a majority of the Northparkes intrusive rocks contain phenocrysts, typically of plagioclase with variable biotite and K-feldspar, so that whole rock analyses may not be fully representative of the parental magma.

\section{Country rock volcanics}

The Goonumbla and Wombin Volcanics follow near identical fractionation trends to one another (Fig. 14). As demonstrated by total $\mathrm{Na}_{2} \mathrm{O}+\mathrm{K}_{2} \mathrm{O}$ vs. $\mathrm{SiO}_{2}$ (TAS; Fig. 14a) and $\mathrm{K}_{2} \mathrm{O}$ vs. $\mathrm{SiO}_{2}$ plots (Fig. 14b) they are typically considered high-K to shoshonitic in character (Heithersay and Walshe, 1995; Crawford et al., 2007; Lickfold et al., 2007). In contrast, the Nelungaloo Volcanics are more consistently classified as basalts to trachyandesites with distinctly lower $\mathrm{K}_{2} \mathrm{O}, \mathrm{Na}_{2} \mathrm{O}$ and $\mathrm{Al}_{2} \mathrm{O}_{3}$ as well as higher overall $\mathrm{Fe}_{2} \mathrm{O}_{3}, \mathrm{CaO}, \mathrm{TiO}_{2}$ and $\mathrm{V}$ concentrations, defining subtly different fractionation trends. 
Intrusions within each volcanic package follow the same fractionation trends and REE profiles as the host volcanics, suggesting they were broadly comagmatic. REE profiles for all the volcanic packages (Fig. 15) lack Eu anomalies, suggesting limited plagioclase fractionation, and only the Wombin Volcanics begin to show a trough-shaped depletion in the middle REE indicative of fractionation of hornblende from the magma prior to eruption or emplacement.

Nearly all fractionation trends (Fig. 14) are smooth and demonstrate compatible behavior of Fe, Ca, Mg, $\mathrm{Mn}, \mathrm{Ti}, \mathrm{V}$ and $\mathrm{Sr}$, likely driven by the continual fractional crystallization of pyroxene and magnetite which are common phases in all the volcanic rocks. Plagioclase phenocrysts are also ubiquitous, but the lack of Eu anomalies and mostly incompatible behavior of Na suggests it was not significantly fractionated, and/or crystallized late in the sequence. Fractionation trends in $\mathrm{Al}_{2} \mathrm{O}_{3}$ are only evident in the Goonumbla and Wombin volcanic rocks; these initially show increasing $\mathrm{Al}_{2} \mathrm{O}_{3}$ until $\mathrm{SiO}_{2} \approx 56 \%$, followed by slight depletion with increasing silica (Fig. 14d). The constant decrease in $\mathrm{P}_{2} \mathrm{O}_{5}$ with increasing silica (Fig. 14g) indicates accessory apatite crystallization throughout. Continual incompatible behavior is displayed by $\mathrm{Zr}$ and $\mathrm{U}$ in all rocks, except some Wombin intrusions, which trend toward lower $\mathrm{Zr}$ concentrations in the most silicic samples (Fig. 14n). This feature is more prominent in the Northparkes intrusive rocks.

The trachyandesites are the most primitive rocks, although, for most elements, they plot broadly along the same fractionation trends as the Goonumbla and Wombin Volcanics (Fig. 14). REE profiles for the trachyandesites are most similar to the Goonumbla Volcanics (Fig. 15). The trachyandesites thus represent potential parental magmas for the entire magmatic suite present in the district.

\section{Northparkes intrusive rocks}

Standard TAS classification (Fig. 16a) shows the suite encompasses monzodiorite through to syenite and granite, with an almost exclusive shoshonitic affinity (Fig. 16b). This agrees with classification based on primary mineralogy, which clearly shows the rocks are dominantly alkaline, i.e. monzonitic to syenitic. Furthermore, significantly-altered samples have been excluded and all remaining samples, regardless of the type or intensity of any hydrothermal alteration developed, follow the expected fractionation trajectory for $\mathrm{K}$ and $\mathrm{Na}$. Thus, the overall classification as shoshonitic does not appear to be influenced by the occurrence of any potassic alteration.

Generally, $\mathrm{Al}_{2} \mathrm{O}_{3}, \mathrm{Fe}_{2} \mathrm{O}_{3}, \mathrm{CaO}, \mathrm{P}_{2} \mathrm{O}_{5}, \mathrm{MgO}, \mathrm{MnO}, \mathrm{TiO}_{2}, \mathrm{Eu}, \mathrm{V}$ and $\mathrm{Sr}$ demonstrate compatible behavior with increasing silica, in agreement with continual fractional crystallization of plagioclase, biotite, magnetite, apatite and minor pyroxene and hornblende (Fig. 16). Some samples, primarily of the BQM, are markedly enriched in $\mathrm{MnO}$ and plot above the well-defined fractionation trend illustrated by most of the data (Fig. 16i). This feature is accounted for by the fact that these samples are propylitically-altered and are located within the whole rock Mn-Zn halo that surrounds the E48 deposit. However, these samples are not obviously anomalous in other elements, hence they are retained in the dataset. 
The intrusive rocks appear to define two distinct fractionation trends (Fig. 16). Initial emplacement and crystallization of the BQM-AFG pluton defines the first 'barren' fractionation series, reaching values of $\mathrm{SiO}_{2}$ $\approx 66 \%$ and in which all HFSE behave incompatibly (e.g., Fig. 16n-q). Subsequent QMZ intrusions appear to have more primitive compositions, at $\mathrm{SiO}_{2} \approx 58 \%$, defining the start of a second 'fertile' fractionation trend toward the K-feldspar-rich QMP intrusions, which ultimately reach $\mathrm{SiO}_{2} \approx 74 \%$. By comparison, this second series exhibits lower $\mathrm{MnO}, \mathrm{P}_{2} \mathrm{O}_{5}, \mathrm{TiO}_{2}$ and $\mathrm{Eu}$, along with slightly higher $\mathrm{Sr}$ concentrations for any given silica content. There is also a highly distinctive, progressive depletion in all HFSE with increasing evolution (e.g., Fig. 16n-q). This feature is not observed in the BQM-AFG series and could, especially for $\mathrm{Zr}$ and $U$, partly reflect a switch to relatively more hydrous, lower temperature magmatic conditions which favour the earlier onset of zircon fractionation (R. Loucks, 2018, pers. comm.). Some BQM samples do however lie upon this trend for $\mathrm{U}, \mathrm{Ho}$ and $\mathrm{Yb}$, and comparable $\mathrm{Zr}$ depletion is apparent in Wombin intrusions (Fig. 14n).

In terms of the REE, there is a systematic lowering in the absolute abundance of all REE (c.f. Fig. 17a-e) and an increasing upward inflection in the $\operatorname{HREE}(E r, Y b, L u)$ from the BQM-AFG pluton, through the QMZ, to the QMP bodies. This is most pronounced in the most REE-depleted, ore-associated, K-feldspar-rich QMP samples, which also start to display positive Eu anomalies (Fig. 17e). There is a return to more typical REE levels in the post-mineralization E34 monzonite porphyry, and even elimination of the Dy minimum in the zero porphyries to yield REE patterns similar to most of the volcanic rocks (c.f. Figs. 15 and 17).

Modelling by Lickfold (2002) demonstrated that the depletion in REE cannot be reproduced by simple fractionation of the REE-rich phases apatite or titanite from a BQM-type melt, although the assumption of this being the direct precursor to the quartz monzonites is open to question. Zircon fractionation alone is also unlikely to be responsible for this trend, given the constant concentration of Zr across a broad range of $\mathrm{SiO}_{2}$ for the QMZ and various QMPs (Fig. 16n). Given that REE profiles for all Northparkes intrusive phases, except the mafic zero and basaltic dikes, show preferential depletion in the middle-heavy REE, essentially Gd to Yb (Fig. 17), it is likely that hornblende fractionation played an important role in controlling the REE geochemistry. This feature is also observed in samples of the Wombin Volcanic Group, with which the Northparkes intrusions appear to be comagmatic, and attests to relatively more hydrous magmatic conditions in comparison to the Goonumbla and Nelungaloo Volcanics. BQM samples may exhibit positive or, more rarely, weak negative Eu anomalies, probably depending on the degree of crowding or dispersion of plagioclase phenocrysts rather than differences in crystallization history (Fig. 17a). The AFG displays a negative Eu anomaly, consistent with plagioclase fractionation (Fig. 17b).

The mafic zero monzonite porphyry reflects a return to more mafic compositions, with $\mathrm{SiO}_{2} \approx 48 \%$. Its composition contrasts markedly with the more evolved zero and E34 monzonite porphyries (Figs. 16 and 17e). The latter two both plot upon the same fractionation series as the QMZ and QMP bodies, suggesting they are related. The last stage of magmatic activity, represented by the basaltic dikes, is the most primitive and samples display the flattest REE profiles, with no evidence of crystal fractionation (Fig. 17f). 


\section{Alteration and veining}

Eight diamond drillholes, totalling $\sim 8 \mathrm{~km}$, were selected to provide broadly lateral traverses away from the central ore zone into distal propylitic alteration at the E26 and E48 deposits (Figs. 4-6). Detailed logging of the lithologies and alteration mineralogy through these holes (Figs. 18 and 19) defined three principal alteration facies that occur as largely concentric zones around each deposit/QMP complex. These comprise: (1) innermost K-feldspar alteration; (2) a shell of magnetite \pm biotite alteration; and (3) outermost propylitic alteration (Figs. 5 and 6).

There is no significant overprinting of the distal alteration assemblages onto the center of the systems. However, sericitic alteration may patchily overprint system centers and also occurs in association with particular vein types. Hematitic reddening of the rock is a further weak alteration type. Argillic alteration is not observed at Northparkes, but a small outcrop of advanced argillic alteration is located nearby at the Nash's Hill prospect (Fig. 3) and potentially represents the remnant of a lithocap.

The characteristics and broad paragenesis of each alteration facies, together with the veins that occur within them, are summarized together; veins that traverse alteration zones are discussed separately. The spatial relationships between veins and alteration zones are illustrated in Figure 20.

\section{Hematite reddening}

Hematitic reddening is a result of $<1 \mu \mathrm{m}$ hematite inclusions developed within micro- to nanoscale pores/cavities in both K-feldspar and plagioclase (e.g. Putnis et al., 2007). Three distinct types of this 'hematite dusting' are recognized based on associated alteration minerals, relationship to veins and spatial extent.

The earliest and most widespread hematite reddening phase affected intrusive rocks and K-feldspar-rich volcanic units, imparting a brick red hue (Fig. 11d, f). Only patches of BQM and pre-mineralization monzodiorite are unaffected (Fig. 11a, b). It is typically weak, but very pervasive and is accompanied by weak, selective sericitization of plagioclase and chloritization of mafic minerals. With increasing intensity, plagioclase is further sericitized and reddened, giving a brown appearance (Fig. 11c). This reddening shows no clear relationship to any specific veins, and intervals of uniform alteration may be encountered that lack macroscopic veins.

Minor, secondary, but strong and selective, hematite dusting of plagioclase in intrusive rocks has affected the outer portions of sericitic alteration halos developed around faults and base metal veins.

The most intense hematite reddening is associated with propylitic alteration. This imparts a characteristic bright, cherry-red coloration to pre-existing K-feldspar around propylitic veins. Secondary albite formed in the outer halo of such veins is also consistently hematite reddened. Pervasive propylitic alteration of intrusive rocks is further associated with additional hematite dusting of feldspars, which may produce dark brownish-red plagioclase. 


\section{K-feldspar alteration and associated veins}

The center of each QMP intrusive complex is characterized by potassium silicate-dominated alteration that encloses the ore zone and comprises K-feldspar-biotite \pm bornite \pm chalcopyrite \pm magnetite. The alteration exhibits a clear spatial and temporal relationship to the K1, K2 and K3 veins described below (Figs. 20 and 21).

\section{K1: Biotite veinlets}

Irregular, often discontinuous veinlets of quartz \pm magnetite ( $<1$ to $2 \mathrm{~mm}$ wide) are surrounded by a texturally-destructive biotite halo 3-10 mm wide (Fig. 21a). This biotite halo is the most distinctive and consistent component of the veins, and sometimes the central quartz seam may be absent. These veins represent the earliest potassic alteration and are consistently cross cut by all other vein types.

\section{K2: K-feldspar-sulfide veinlets}

Fine, irregular and discontinuous quartz-K-feldspar-bornite \pm chalcopyrite veinlets $(<1.5 \mathrm{~mm}$ wide) are surrounded by 1-3 $\mathrm{mm}$ wide K-feldspar alteration halos which bleed out into the surrounding rock. These veinlets form extensive, intricate networks in the cores of the deposits (Fig. 21b, c). At least two generations are observed at E26 and E48, where they both cut, and are cross cut by, K3 veins.

\section{K3: Quartz-sulfide veins}

The principal quartz vein stockwork within the deposits comprises reasonably straight, quartz-bornite \pm chalcopyrite \pm anhydrite veins (Fig. 21c-f). These are typically 5-20 mm wide but range between $3 \mathrm{~mm}$ and $20 \mathrm{~cm}$. Sulfides are sparsely disseminated throughout the vein or, together with K-feldspar, may form margin-parallel trails indicative of reopening. Vein margins are sharp but locally undulate. They characteristically have pink K-feldspar alteration halos, except where these have been obliterated by later sericitic overprinting (Fig. 21e). At least two generations exist at E26 and E48, where these veins are observed to cross cut one another.

Quartz-K-feldspar-sulfide veins (K2 and K3) are responsible for ore-grade mineralization and are intimately related to large-scale, pervasive alteration. Where these veins are developed in felsic host rocks (trachytes, ignimbrites and BQM-AFG pluton) the K-feldspar alteration halos are the widest (Fig. 21b, d). In areas of particularly high vein density, K-feldspar-quartz alteration floods the surrounding rock, and irregular patches of biotite and disseminated sulfides are developed throughout this zone of flooding (Fig. 21b). In relatively mafic host rocks (e.g., trachyandesites and volcaniclastics), K-feldspar alteration halos are limited to only a few millimeters wide, and the surrounding rock is pervasively biotite-magnetite altered (Fig. 21c, f), again with disseminated sulfides throughout.

\section{Magnetite \pm biotite alteration and associated veins}

With increasing distance from centers of mineralization, the density of K2 and K3 quartz-K-feldspar-sulfide veins decreases from hundreds of veins per meter to approximately ten or less per meter. This is 
accompanied by a strong decrease in K-feldspar and $\mathrm{Cu}$ sulfides, a minor decrease in biotite, and a simultaneous increase in the abundance of disseminated magnetite, thus defining a magnetite \pm biotite alteration shell around the deposits (Figs. 18-20). Although K2 and K3 veins may sparsely persist into this zone, K1 veins do not (Fig. 20). The vein types that are characteristic of this zone are magnetite veinlets (M1) and magnetite-chalcopyrite \pm quartz veins (M2).

\section{M1: Magnetite veinlets}

Minor, irregular, magnetite-only veinlets ( $<5 \mathrm{~mm}$ wide) are found rarely throughout the magnetite-biotite alteration shell that developed in mafic volcanic rocks (Figs. 20 and 21f). The veinlets are considered early, lateral equivalents of $\mathrm{K} 1$ biotite veinlets, and are cross cut by $\mathrm{K} 2$ and $\mathrm{K} 3$ quartz-K-feldspar-sulfide veins.

\section{M2: Magnetite veins}

Veins, $1-5 \mathrm{~cm}$ wide, dominated by magnetite with minor chalcopyrite \pm quartz occur rarely within the magnetite \pm biotite alteration shell. Their timing is uncertain, but the mineralogy suggests they were broadly synchronous with magnetite-biotite alteration.

The transition from innermost K-feldspar to magnetite \pm biotite alteration typically occurs over 100-200 m. Host lithology strongly controls the occurrence and appearance of the magnetite \pm biotite shell. Within mafic host rocks it is encountered $\sim 200-300$ m laterally from the system center and comprises intense and pervasive, fine, disseminated magnetite and biotite that impart a dark grey to black coloration which obscures original textures (Fig. 21g). Within felsic rocks, magnetite \pm biotite alteration may not be encountered until $\sim 500 \mathrm{~m}$ from the system center, where it forms disseminated clots of magnetite with minor biotite around original mafic crystal sites. Minor, weak and selective sericitic alteration of plagioclase and K-feldspar is also observed (Fig. 21h).

Further biotite-magnetite is weakly, but pervasively, developed within mafic volcanic rocks adjacent to the BQM-AFG pluton, effectively forming a contact metamorphic aureole. This assemblage shows no relationship to veins and may be strongly overprinted by propylitic alteration.

\section{Propylitic alteration and associated veins}

With continued distance from centers of mineralization, disseminated specks of epidote and chlorite begin to occur within high permeability volcanic units in the outer parts of the magnetite-biotite alteration shell. Within relatively impermeable intrusive rocks, epidote and chlorite first occur as selective replacement minerals, developed in and around mafic crystal sites. Eventually, epidote veinlets (P3) are encountered and followed, with increasing vein density, by larger epidote-chlorite-albite (P2) and chlorite-quartzepidote-albite (P1) veins (Fig. 20; see vein descriptions below). These are accompanied by further development of disseminated epidote, chlorite, pyrite and hematite-reddened albite, which together define the propylitic alteration zone. Rare actinolite has also been reported from the innermost part of the propylitic alteration zone at E27 (J. Hoye, 2015, pers. comm.). Epidote and chlorite are typically developed at the expense of any pre-existing magnetite and biotite. The transition between magnetite-biotite and 
propylitic alteration zones typically occurs over $100-200 \mathrm{~m}$. In the Northparkes area, propylitic alteration is the most widespread facies, visibly extending $2-3 \mathrm{~km}$ from mineralized centers, but is generally most intense at distances of 1-1.5 km.

Propylitic alteration is most pervasive within mafic volcanic and volcaniclastic lithologies, probably as a result of their intrinsic elevated permeability and relatively high $\mathrm{Fe}, \mathrm{Mg}$ and $\mathrm{Ca}$ contents (e.g., Fig. 22a-c). Fluid flow was clearly controlled by both fractures and intergranular permeability within the volcanosedimentary packages (e.g., Fig. 22b), with propylitic alteration being strongest in regions of high vein density and in the most permeable, coarse grained units, following and highlighting original bedding and laminations. Alteration mineral grain size is generally related to that of the original rock components that have been replaced, although distinct clots of epidote \pm quartz \pm chlorite formed locally (Fig. 22c).

In all competent, relatively low permeability igneous rocks, propylitic alteration is distinctly fracturecontrolled. Intense alteration is only observed within and around large veins (mostly P1) or in zones of high vein density (mostly P2), grading out into moderate to weak alteration associated with numerous epidote veinlets (mostly P3; Fig. 20). Chlorite \pm epidote replacement of original mafic minerals and albite-hematite replacement of plagioclase are the features noted furthest from veins (Fig. 22g). Between propylitic domains, rocks containing relict magnetite with only mild hematite reddening may be preserved.

Propylitic alteration is most weakly developed in the AFG, trachytes and trachytic ignimbrites, probably owing to the abundance of relatively unreactive K-feldspar. Nonetheless, epidote-dominated veins (P2 and P3) do occur in these units and plagioclase, biotite or mafic phenocrysts are selectively propylitically-altered whenever they are present.

\section{P1: Chlorite-quartz-epidote-albite veins}

Complex veins, comprising central infills of chlorite-quartz-pyrite \pm calcite \pm hematite (dark red) \pm epidote \pm rare chalcopyrite, are characteristically surrounded by pervasive and intense alteration halos with a distinct mineralogical zonation (Fig. 22d-g). The vein-proximal assemblage consists of chlorite and sericite (phengite) \pm epidote \pm pyrite; this grades outwards to hematite-sericite-chlorite \pm epidote and, eventually, to hematite-albite \pm chlorite \pm epidote. Plagioclase and biotite in the proximal halo are usually selectively replaced by near pure chlorite, with an intergrowth of phengite-chlorite grains $(\leq 10 \mu \mathrm{m})$ replacing all other minerals, including K-feldspar. Plagioclase in the outermost halo is replaced by albite, which is hematite reddened along with original $\mathrm{K}$-feldspar; biotite is still chloritized. These mineralogical transformations imply at least some metasomatic addition of $\mathrm{H}, \mathrm{Mg}$ and $\mathrm{Fe}$, the latter reaching furthest from the vein.

The veins themselves range from $5 \mathrm{~mm}$ to $15 \mathrm{~cm}$ wide and are typically sheared, with margin-parallel traces of hematite and/or pyrite providing evidence of reopening. The original vein fill appears limited to quartzchlorite \pm pyrite, with the majority of calcite and hematite precipitated later. Corresponding vein halos are particularly large, with alteration extending $4 \mathrm{~cm}$ to $>4 \mathrm{~m}$ either side of the center, in proportion to the 
width of the vein fill (Fig. 22g). These features suggest the fluid was in strong disequilibrium with the wall rock.

\section{P2: Epidote-chlorite-albite veins}

The most abundant propylitic veins (Fig. $22 \mathrm{~h}-\mathrm{k}$ ) are typically straight and contain a central fill, 2-20 mm wide, of epidote-chlorite \pm calcite \pm quartz \pm pyrite. When present, quartz-calcite-pyrite form an interstitial cement to epidote crystals, which are interspersed with occasional chlorite and occur along the vein edges, growing inwards from each margin (Fig. 22j). Epidote may also locally infiltrate a few millimeters into the wall rock, making the margin appear indistinct. Surrounding these veins is a characteristically zoned alteration halo with three main sub-divisions (Fig. 22h, i). Vein-proximal alteration consists of intense chlorite and sericite (phengite), often with minor epidote and pyrite, as described for P1 veins. This grades out into a middle envelope, rich in epidote, that is present either as a distinct vein-parallel layer or series of patches. Vein-distal alteration is dominated by albite which, along with relict K-feldspar, is markedly hematite reddened; minor patches of chlorite and epidote alteration also persist. Alteration intensity then gradually decreases back into weak but pervasive 'background' propylitic alteration. The alteration halo of these veins extends for $3-20 \mathrm{~cm}$ either side of the vein center, again depending on vein width. Such alteration transitions, within a rock of BQM-type composition, may be simply interpreted in terms of the bulk, vein-proximal, metasomatic addition of $\mathrm{H}$ and $\mathrm{Mg} \pm \mathrm{Fe}$ (to give a chlorite-sericite assemblage), during which $\mathrm{Ca}$ is locally leached. The $\mathrm{Ca}$ is then mobilized outwards into the middle envelope where, with continued $\mathrm{H} \pm \mathrm{Fe}$ metasomatism and oxidation of $\mathrm{Fe}$ to $\mathrm{Fe}^{3+}$, it resides within epidote.

\section{P3: Epidote veinlets}

Fine ( $1 \mathrm{~mm}$ wide), erratic and often discontinuous epidote \pm chlorite \pm pyrite veinlets are found throughout the propylitic zone, particularly within igneous rocks where they may be the only observable evidence of fluid migration in areas of moderate to weak propylitic alteration. Epidote is developed to a variable extent around the veinlets into surrounding wall rocks, especially where plagioclase crystals were intersected, producing a highly irregular, blebby margin (Fig. 22I, m). Alteration halos, typically $1-2 \mathrm{~cm}$ wide, are developed around these veinlets, characterized by hematite reddening of any pre-existing feldspar and selective replacement of plagioclase and biotite by epidote and chlorite respectively.

\section{Vein relationships and timing}

Propylitic veins exhibit a consistent spatial relationship to one another. The largest and rarest P1 (chloritequartz-epidote-albite) veins are typically surrounded by zones in which P2 (epidote-chlorite-albite) veins dominate. The P2 veins have compositional characteristics that are essentially intermediate between P1 and P3 veinlets and are routinely enclosed by areas rich in P3 epidote veinlets (Fig. 20). Thus, the vein types appear to be related and are interpreted to represent a continuum (P1 $\rightarrow$ P2 $\rightarrow$ P3) reflecting a broadly decreasing outward flux of fluid that passed through the fracture network. Although all propylitic veins appear broadly synchronous, it is noted that some $\mathrm{P} 1$ and $\mathrm{P} 2$ veins may cut $\mathrm{P} 3$ veinlets. 
The occurrence and intensity of all observed propylitic alteration is directly controlled by three factors: (1) distance from mineralized centers; (2) permeability, as a result of lithology, geological contacts and the abundance of microfractures through to large fracture/fault zones; (3) host rock composition/reactivity. There is no observable correlation between the intensity and/or occurrence of propylitic alteration with the BQM-AFG pluton.

Country rock xenoliths within the BQM and AFG show no signs of previous alteration. In contrast, xenoliths within QMP units frequently show evidence of prior biotite-magnetite and, in the latest QMP units, Kfeldspar-sulfide alteration-mineralization in the form of truncated veins. Fragments of $P 1$ and $P 2$ veins and propylitically-altered rocks are found within both post-mineralization monzonite porphyries and pebble dikes (Figs. 13h and 22d, n). Base metal veins have cut and reopened P1 veins and are themselves included as fragments within the pebble dikes.

These observations are consistent with the bulk of propylitic alteration forming during mineralization as the distal equivalent to the central potassic zones, driven by the focused release of magmatic fluid through the QMP intrusions. A close relationship to mineralization is again indicated by the rare presence of chalcopyrite, K-feldspar and, at E26, anhydrite within P2 veins (Fig. 22k). Nonetheless, some late stage, relatively weak propylitic alteration, mainly limited to disseminations around P3 veinlets, must have taken place after mineralization because it occurs within post-mineralization monzonite porphyries and exploited pebble dikes (Fig. 220).

\section{Regional metamorphism vs. propylitic mineral assemblages}

The Northparkes propylitic alteration halo is visually distinct from the surrounding low-grade, regional metamorphic assemblage. The latter is dominated by chlorite, but commonly contains prehnite, pumpellyite and zeolites. Albite occurs locally, but no feldspars are hematite reddened and no pyrite is present. Metamorphic epidote is rare and, in comparison to propylitic alteration, is fine grained (usually only 10-30 $\mu \mathrm{m}$ ). Also, despite being exceptionally pervasive, development of the metamorphic assemblage shows no clear link to fractures or veins which are relatively uncommon. When encountered, veins are typically only a few millimeters wide, are composed of calcite with lesser epidote and lack distinct alteration halos, indicating near fluid-rock equilibrium.

\section{Sericitic alteration}

Where analysed via SEM-EDS, all alteration minerals referred to as sericite are dominated by phengite/phengitic muscovite, but the field term sericite is retained in this paper because not all examples have been investigated in detail. Several distinct, sericite-dominant alteration facies can be recognized at Northparkes. The most common is locally developed around late- to post-mineralization faults, often comprising total, but texturally enhancing replacement by variously colored assemblages of sericite-quartz \pm pyrite. However, more distinctive are the pervasive and texturally-destructive regions of characteristically white sericite-albite-quartz-alunite \pm chlorite alteration that overprint the potassic core of E48 (Fig. 21e), 
and have been encountered at GRP314 (Wolfe, 1994; Hendrawan, 2011a). This alteration is most extensive at depth within favorable felsic lithologies, particularly the BQM-AFG pluton, and contains tennantite as a major Cu-bearing phase. Wolfe (1996) demonstrated a magmatic fluid origin for this alteration at E48. Sericitic alteration is also a defining characteristic of the sericitic veins described below.

\section{Veins that transect alteration zones}

Barren quartz veins

Two generations of sharp, straight-walled, quartz-only veins (5-30 mm wide) occur in a low-density barren stockwork at $1.2 \mathrm{~km}$ depth, 600 m east of E26 (e.g., Fig. 20); vein halos consist only of hematite reddening of feldspars. The source and significance of these veins is unknown. Timing is also poorly constrained, but they are probably pre- to early- mineralization, given that they are both overprinted and reopened by P3 epidote veinlets, and cut by the base metal veins. Wolfe (1994) reported similar veins at depth below E48.

\section{Sericitic veins}

Within and around E26 and GRP314, sericitic (variably phengitic muscovite) alteration is localized around a distinct set of veins that are typically straight and commonly sheeted. Vein centers are usually thin $(<1 \mathrm{~mm}$ to $20 \mathrm{~mm}$ wide) and comprise quartz and/or anhydrite \pm pyrite \pm chalcopyrite \pm molybdenite \pm magnetite. These are enclosed by proportionally much wider ( 1 to $150 \mathrm{~cm}$ respectively), well-developed and notably zoned alteration halos (Fig. 23).

Vein-proximal alteration consists of intense, pervasive and texturally-destructive grey quartz-sericite-pyrite \pm molybdenite, and vein intersections may be associated with large domains of such alteration. These veinproximal zones are enveloped by an outer fringe of variable alteration mineralogy. At E26, this vein-distal alteration shows a progressive change dependant on the relative distance of the vein from the deposit. Within the center of E26 it comprises a well-developed K-feldspar and biotite assemblage (Fig. 23a, b) which decreases in intensity at distances of between $150-300 \mathrm{~m}$ (Fig. 23C). With still increasing distance, between $\sim 300-600 \mathrm{~m}$ from E26, chlorite \pm sericite (phengite) is developed instead (Fig. 23d-f) and is accompanied by epidote-hematite at $>600 \mathrm{~m}$ (Fig. 23g, h) to give propylitic alteration. The width of the sericitic veins and associated alteration halos also generally decrease to $<5 \mathrm{~mm}$ and $2-3 \mathrm{~cm}$, respectively, with progression away from E26.

At least two generations of sericitic veins exist. These can cut one another and may either cut, or be cut by, K-feldspar veinlets (K2), quartz-sulfide veins (K3) and epidote veinlets (P3). This implies a temporal overlap between the sericitic veins and mineralizing magmatic-hydrothermal activity. A magmatic origin for the sericitic alteration halo of these veins around E26 was also established by Harris and Golding (2002). Consequently, the sericitic veins are a pertinent example of how a magmatic-derived ore fluid can drive not only potassic and sericitic, but also propylitic alteration, dependant on physicochemical conditions. 


\section{Base metal veins}

Quartz-calcite \pm anhydrite veins, typically $<1-10 \mathrm{~cm}$ wide, containing pyrite, sphalerite and chalcopyrite with minor galena, bornite and molybdenite (Fig. 24a, b) are present within the core and periphery of all Northparkes deposits, but are most abundant in relatively distal locations. Veins are internally zoned from pyrite-quartz-dominant margins to sphalerite-chalcopyrite-dominant centers and are surrounded by pervasive, texturally-destructive quartz-sericite (phengite) \pm pyrite \pm chlorite alteration halos extending 0.3-2 $\mathrm{m}$ either side. Sphalerite shows a characteristic internal zonation from low-Fe, light honey-brown cores to black, high-Fe rims (Fig. 24a, b).

The base metal veins may cut and reopen both sericitic and P1 propylitic veins (Figs. 20 and 24b) but are, in turn, cut by gypsum-anhydrite veins. Although clearly late-mineralization in timing, the exact origin of the base metal veins remains poorly constrained. However, the occurrence of sphalerite in some anhydritequartz veins (Fig. 24h), and a lack of cross cutting relationships between the base metal and anhydritequartz veins perhaps suggests the two are related.

\section{Anhydrite-quartz veins}

Veins, 1-30 cm wide, of dark purple anhydrite, or gypsum, and quartz (locally with comb growth textures) \pm pyrite \pm chalcopyrite \pm magnetite \pm sphalerite, are found around and within the central intrusive complex at E26 and GRP314 (Fig. 20). Irregular segregations of purple anhydrite within aplitic, late-mineralization, Kfeldspar-rich QMP intrusions, with surrounding intense K-feldspar-biotite alteration (Figs. 13c and 24c), are probably the origin of these veins.

Where observed immediately adjacent to QMP intrusions, the anhydrite-quartz veins are surrounded by strong K-feldspar-biotite alteration and contain limited sulfides (Fig. 24d). However, in relatively depositdistal locations, the anhydrite-quartz veins display quartz-sericite halos and contain chalcopyrite, pyrite, magnetite and rare sphalerite (Fig. 24e-h). Most of the anhydrite-quartz veins occur adjacent to, or within, sericitic veins, which they have reopened and brecciated (Fig. 24e-g).

\section{Gypsum-anhydrite veins}

Barren, pale pink to light purple anhydrite veins ( \pm rare pyrite), $<1-50 \mathrm{~cm}$ wide and lacking alteration halos are observed around E26 and GRP314 (Fig. 24r). At shallow depths, the anhydrite has been hydrated to distinctive, fibrous gypsum (Figs. $23 f$ and $24 r$ ). Such veins are most frequently observed to have cut, or more rarely reopened, sericitic veins, anhydrite-quartz veins and base metal veins. P3 epidote veinlets are consistently truncated by the gypsum-anhydrite veins (Fig. 24r).

\section{Calcite veins}

Veins of calcite \pm rare quartz consistently occur along fractures and are particularly common within the center of the base metal veins (Fig. 24a) and anhydrite-quartz veins, recording a final stage of reopening. The calcite veins commonly display central, crystal-lined vugs, comb textures and calcite locally cements 
brecciated fragments of previous vein material. These are the latest vein generation recognized at Northparkes.

\section{Discussion: Geological evolution of the Northparkes system}

The Goonumbla and Wombin Volcanics document the Middle to Late Ordovician development of the Macquarie Island Arc. These dominantly submarine volcano-sedimentary packages reflect an overall transition toward more felsic, evolved magmatism of shoshonitic affinity. However, a bimodality is demonstrated by the emplacement of large volumes of basaltic trachyandesite sills into the succession, at least in part whilst it was still water-saturated and unconsolidated. Conglomerates and volcanic breccias at Northparkes are considered lateral equivalents to generally deep-water sands and silts elsewhere in the district, with occasional shallow water limestone intercalations. Thus, the envisaged depositional environment is upon the flanks of a largely submerged volcanic edifice, host to debris avalanches and surrounding carbonate banks (Simpson et al., 2005), perhaps behind the main arc front. At least part of the volcanic system was emergent by the Late Ordovician, with explosive eruptions documented by welded ignimbrites.

It is unclear if surface volcanism continued during porphyry magmatic-hydrothermal activity, although the Northparkes intrusive rocks share a similar geochemistry and broad timing to rocks of the Wombin Volcanics, indicating a potential genetic relationship. There is no evidence of wet-sediment interaction during emplacement of the monzodiorite or BQM-AFG plutons, and a magmatic body of such volume would be unlikely to stall and crystallise close to the surface with the observed coarse, equigranular (plutonic) textures. This is supported by several fluid inclusion studies of mineralized veins which suggest that, assuming lithostatic fluid pressures, ore formation occurred at minimum depths of 1-1.7 km (1-1.7 km given by Lickfold et al., 2003; $1.7 \mathrm{~km}$ calculated here using the fluid entrapment pressures of 400-500 bar reported by Heithersay and Walshe, 1995).

Unfortunately, an emplacement sequence cannot be resolved by geochronology given that available age estimates of several intrusive phases overlap within error. However, the data demonstrate that most intrusive activity and associated alteration took place in the latest Ordovician to earliest Silurian. In comparison, the relative timing of magmatic-hydrothermal events is particularly well constrained by field relationships and forms the basis for the following interpretation of the geological evolution at Northparkes.

\section{Stage 1: Pre-mineralization magmatism}

Initial pre- to early-mineralization emplacement of the BQM-AFG pluton resulted in biotite-magnetite hornfelsing of the surrounding volcanics and would have likely driven any formation waters away from the system. Prior to total solidification, bodies of QMZ were then injected into the pluton. This magmatic phase marks a brief return to slightly more primitive magmatism and the initiation of a fertile and significantly more hydrous fractionation series, likely favouring zircon and hornblende fractionation. The $Q M Z$ shares 
some characteristics with the later QMPs: upper portions of the intrusions are porphyritic, with K-feldspar phenocrysts and disseminated $\mathrm{Cu}$ sulfides. However, the $\mathrm{QMZ}$ is not associated with any well-developed veining, rather, it appears that any fluids remained trapped in the melt.

\section{Stage 2: Principal magmatic-hydrothermal activity}

Subsequent magmatism generated the highly evolved QMP complexes and mineralizing hydrothermal systems. By this time, all presently observed levels of the BQM, AFG and QMZ had completely solidified. Several QMP intrusions are present in each deposit and similar porphyries are associated with the many prospects across the Northparkes district. Multiple QMP intrusions are present in each intrusive complex and may span the mineralizing episodes. However, those QMPs most enriched in K-feldspar and containing fewer mafic minerals are associated with the strongest mineralization and appear to be most intimately linked to the hydrothermal systems.

The QMPs are ubiquitously crystal crowded and K-feldspar altered. Such crowding in a typical felsic magma would commonly be thought to produce a very high viscosity, yet, at Northparkes, these magmas infiltrate into even the smallest fractures $(<1 \mathrm{~mm})$ in surrounding volcanic rocks. Further, large zones of USTs, irregular miarolitic cavities and broken, angular phenocrysts are present, and intrusive brecciation is commonplace. All such observations attest to the forceful, possibly explosive, emplacement of a highly volatile-rich, low viscosity 'magma', perhaps better thought of as a crystal-bearing, silicate melt-aqueous fluid slurry (R. Armstrong, 2015, pers. comm.).

At a particular depth (confining pressure), magmatic fluid was discharged around the margins and through the apices of the intrusions. The timing of intrusive activity and mineralization at each deposit, relative to one another, remains unknown. However, initial fluid evolution appears similar across all the QMP complexes. Early-mineralization QMP units are associated with biotite-magnetite alteration, including biotite and magnetite veins (K1 and M1). Subsequent K-feldspar-rich QMP units generated overprinting Kfeldspar-sulfide veinlets and quartz-sulfide stockwork veins (K2 and K3), in turn forming the deposit-central $\mathrm{K}$-feldspar alteration zone. At least two generations of $\mathrm{K} 2$ and $\mathrm{K} 3$ veins are present at E48 and E26 as a result of multiple QMP intrusions, helping to boost ore grade.

Intense, deposit-peripheral, magnetite-biotite and propylitic alteration shells are constrained to occur simultaneously with mineralization and the central K-feldspar alteration. The clear spatial and temporal links between these alteration facies strongly suggests they were formed by a dominantly magmatic fluid as it was expelled outwards from the intrusive complexes, progressively cooling and equilibrating with the country rock. Fluid evidently infiltrated through permeable volcanic units and fracture zones. Within the magnetite \pm biotite shell, fine, disseminated magnetite and biotite was developed throughout permeable volcanics or formed distinct alteration clots in intrusive rocks; magnetite veins (M2) occur across the facies. Within the propylitic zone, fluid was principally supplied through large fractures in which chlorite-quartzepidote-albite (P1) veins formed; these grade into progressively smaller-scale epidote-chlorite-albite (P2) 
veins and epidote veinlets (P3) that appear to represent the more distal parts of a linked fracture mesh. The ubiquitous alteration halos documented around these propylitic veins attest to a fluid in strong disequilibrium with wall rocks. Disseminated and clotty epidote and chlorite were also developed throughout most permeable units.

Late-stage evolution of the Northparkes deposits is variable. At E22 and E27 there is no further significant alteration, but late-mineralization QMP intrusions and sericitically-altered faults are recognized. In the core of E48 (and parts of GRP314), an acidic magmatic fluid of uncertain origin caused intense, pervasive and texturally-destructive white sericite-albite-quartz-alunite \pm chlorite alteration. At E26 and GRP314, cooler, late magmatic fluid was structurally focused, forming the sericitic veins, characterized by vein-proximal grey quartz-sericite \pm pyrite alteration halos. These halos grade outwards into a variable, vein-distal assemblage in which mineralogy is broadly controlled by distance to the intrusive complexes.

\section{Stage 3: Late-mineralization magmatic-hydrothermal activity}

Late-mineralization QMP intrusions were emplaced at E26 and GRP314. They contained a significant amount of immiscible fluid, represented by common anhydrite-quartz-aplite \pm biotite segregations and USTs. Such large quantities of anhydrite suggest oxidized conditions prevailed. Escape of this fluid, mostly through pre-existing weaknesses (sericitic veins), appears to have generated anhydrite-quartz veins, some of which contain notable sphalerite. Base metal veins, also characterized by sphalerite, are present throughout Northparkes and may be genetically related to this event. The exact origin of the base metal veins remains unknown, although certain phases must post-date the propylitic (P1 and P2) and sericitic veins. Remaining fluid activity at E26 and GRP314 was restricted to barren anhydrite \pm pyrite veining.

\section{Stage 4: Post-mineralization magmatism}

Continued post-mineralization magmatism is evidenced by the mafic zero and zero monzonite porphyries, which were emplaced as SE-striking composite dikes. Their compositions again indicate a return to relatively primitive magma conditions.

The exact timing of the post-mineralization monzonite porphyry at E34 is presently unknown but intrusion of this phase appears to have generated at least some of the widespread pebble dikes. If these breccia dikes were generated by phreatomagmatic activity, then the local country rock units must have been water-saturated by this time, perhaps indicative of surface exhumation, or ingress of water as a result of significant cooling of the magmatic system. The pebble dikes cut all mineralization and veins, including the sericitic, base metal and propylitic (P2 and P3) veins; Lickfold (2002) also reported fragments of the zero porphyry within them.

Weak propylitic alteration persisted slightly beyond this late magmatic activity, affecting the monzonite porphyries and locally exploiting pebble dikes as conduits. It is limited to P3 epidote veinlets and selective replacement of mafic minerals and, more rarely, plagioclase. 
Final, thin, alkali basalt dikes cut through the Northparkes district and are either unaltered or selectively overprinted by cream-colored quartz-sericite. Some dikes were emplaced along the Altona Fault.

As a consequence of the underlying plutonic mass, the Northparkes area escaped major deformation during tectonic accretion and related orogenies. The low angle Altona Fault is the most significant feature developed during deformation, transecting the top of the E48 and GRP314 mineralized systems.

\section{Conclusions}

The geology at Northparkes records over $60 \mathrm{Ma}$ of volcanic evolution within the Macquarie Island Arc, culminating in latest Ordovician to earliest Silurian porphyry Cu-Au mineralization. All volcanic and intrusive rocks are silica-saturated but distinctively alkaline/shoshonitic in character. Most magmatism occurred prior to ore formation, including both extensive seafloor volcanism and coeval intrusions into the volcanic pile. The deposits are located within a major volcanic-plutonic center, founded upon a large monzonite to alkali granite intrusion that may represent an original shallow crustal magma chamber. The emplacement of trachyandesite sills, the $\mathrm{QMZ}$ and several post-mineralization monzonite porphyry phases provide evidence for periodic returns to more primitive magmatic conditions.

Mineralization was caused by the forcible, periodic escape of low viscosity, crystal- and volatile-rich magmas. These exploited pre-existing structural intersections and focused the discharge of large quantities of magmatic fluids from the underlying chamber. The fluids circulated in intricate fracture networks to produce K-feldspar-sulfide veinlets and quartz-sulfide stockwork veins, surrounded by K-feldspardominated alteration. Ore grades are exclusively located within the potassic alteration zones, although some have been sericitically overprinted. Spent fluids continued to be driven outwards, presumably as a result of thermal buoyancy and magmatic overpressure, infiltrating both laterally and upwards into the surrounding pluton and volcano-sedimentary packages through pre-existing faults/fractures and permeable units. Progressive cooling and equilibration of these fluids toward lower water:rock ratios formed a shell of magnetite-biotite alteration and, ultimately, they appear to have driven the widespread peripheral propylitic alteration. The mineralogy, complex alteration halos and spatial relationships between propylitic veins provides compelling evidence of such an outwards flux of fluid as it progressively approached nearequilibrium conditions with the country rocks via physical and chemical exchange. Indeed, the appearance of each alteration facies at any point is a function of host rock composition, permeability, vein/fracture density and distance from the system center.

Despite broadly similar characteristics, each individual deposit at Northparkes is unique and generated a distinct hydrothermal system. Magmatic-hydrothermal breccias are common at E27, whereas anhydrite is particularly abundant only at E26 and GRP314, where it is associated with late-mineralization QMP intrusions. Significant sericitic alteration is lacking at E22 and E27, but uniformly overprints much of the core at E48 and is vein-related at E26 and GRP314. Systematic spatial changes to the alteration envelope around sericitic veins at E26 (from deposit-proximal K-feldspar \pm biotite to deposit-distal chlorite-epidote- 
hematite) provide a key example of how a magmatic fluid can evolve to create numerous alteration domains.

\section{Acknowledgments}

Thanks must go to AMIRA and the corporate sponsors of AMIRA project P1060 who provided industry support and funding for much of this research. Rb-Sr isotope analyses were independently funded in the UK through NERC grant IP-1541-0515. The SEG Foundation Scholarship awarded to AP is also gratefully acknowledged. We are indebted to Rio Tinto Plc and China Molybdenum Co. Ltd for logistical and additional financial assistance with this work and permission to publish. Richard Lesh also generously provided several of the photographs used in this paper. AP wishes to extend thanks to all members of both the geology team at Northparkes and LODE research group at the NHM for their help, support and encouragement. Finally, we are grateful for the detailed reviews of this paper by John Thompson and Jeremy Richards which helped improve the text.

\section{References}

Arundell, M. C., 1997, Goonumbla: Twenty-five years, four deposits, fifty-two prospects and still drilling: 3rd International Mining Geology Conference, Melbourne, 1997, p. 183-187.

Blevin, P. L., and Morrison, G. W., 1997, Magmatic and hydrothermal evolution of major intrusive related gold deposits, AMIRA P425, Final Report, Parts 11 and 14 (unpublished).

Butera, K. M., Williams, I. S., Blevin, P. L., and Simpson, C. J., 2001, Zircon U- Pb dating of Early Palaeozoic monzonitic intrusives from the Goonumbla area, New South Wales: Australian Journal of Earth Sciences, v. 48, p. 457-464.

China Molybdenum Co., Ltd. (CMOC), 2018, 2017 Annual Report (http://www.chinamoly.com/06invest/DOC/2018/E_03993_04207.pdf)

Clarke, I., 1990, Igneous Petrology, in Clarke, I., and Sherwin, L., eds., Record 23 - Geological setting of copper deposits in the Parkes area, New South Wales: Sydney, New South Wales Geological Survey, p. 95-136.

Clissold, M. E., Leverett, P., and Williams, P. A., 2005, Chemical mineralogy of the oxidized zones of the E22, E26 and E27 ore bodies at Northparkes, New South Wales: Regolith 2005 - Ten Years of CRC LEME, Adelaide and Canberra, 2005, p. 55-58.

Cohen, K. M., Finney, S. C., Gibbard, P. L., and Fan, J. X., 2013, The ICS International Chronostratigraphic Chart: Episodes, v. 36, p. 199-204.

Cooke, D. R., Wilson, A. J., House, M. J., Wolfe, R. C., Walshe, J. L., Lickfold, V., and Crawford, A. J., 2007, Alkalic porphyry $\mathrm{Au}-\mathrm{Cu}$ and associated mineral deposits of the Ordovician to Early Silurian Macquarie Arc, New South Wales: Australian Journal of Earth Sciences, v. 54, p. 445-463.

Crane, M. J., Sharpe, J. L., and Williams, P. A., 1998, The mineralogy of the oxidized zones of the E22 and E27 orebodies at Northparkes, New South Wales: Australian Journal of Mineralogy, v. 4, p. 1-8.

Crawford, A. J., 2001, Tectono-magmatic development of the Ordovician volcanic belts in central western NSW, and the timing and location of porphyry-style mineralisation within the Macquarie Arc, in Crawford, A. J., Cooke, D. R., and Glen, R. A., eds., NSW Ordovician SPRIT report: Hobart, p. 7.417.52 .

Crawford, A. J., Cooke, D. R., and Glen, R. A., 2001, NSW Ordovician SPIRT Report: Hobart, University of Tasmania Centre for Ore Deposit Research, p. 510. 
Crawford, A. J., Meffre, S., Squire, R. J., Barron, L. M., and Falloon, T. J., 2007, Middle and Late Ordovician magmatic evolution of the Macquarie Arc, Lachlan Orogen, New South Wales: Australian Journal of Earth Sciences, v. 54, p. 181-214.

Dalstra, H., and Oosterwijk, L., 2005, Structural assesment of the Altona Fault, Northparkes mining district, NSW: Unpublished Northparkes Mines report.

Glen, R. A., Crawford, A. J., Percival, I. G., and Barron, L. M., 2007, Early Ordovician development of the Macquarie Arc, Lachlan Orogen, New South Wales: Australian Journal of Earth Sciences, v. 54, p. 167-179.

Glen, R. A., Quinn, C. D., and Cooke, D. R., 2012, The Macquarie Arc, Lachlan Orogen, New South Wales: its evolution, tectonic setting and mineral deposits: Episodes, v. 35, p. 177-186.

Glen, R. A., and Walshe, J. L., 1999, Cross-structures in the Lachlan Orogen: the Lachlan Transverse Zone example: Australian Journal of Earth Sciences, v. 46, p. 641-658.

Glen, R. A., Walshe, J. L., Barron, L. M., and Watkins, J. J., 1998, Ordovician convergent-margin volcanism and tectonism in the Lachlan sector of east Gondwana: Geology, v. 26, p. 751-754.

Gray, D. R., and Foster, D. A., 2004, Tectonic evolution of the Lachlan Orogen, southeast Australia: historical review, data synthesis and modern perspectives: Australian Journal of Earth Sciences, v. 51, p. 773817.

Gray, D. R., Foster, D. A., and Bucher, M., 1997, Recognition and definition of orogenic events in the Lachlan Fold Belt: Australian Journal of Earth Sciences, v. 44, p. 489-501.

Hall, M. C., 1993, The stratigraphy and palaeovolcanology of the Late Ordovician Goonumbla Volcanics, Goonumbla, N.S.W: Unpublished BSc (Hons) thesis, Monash University.

Harris, A. C., 1997, Vein emplacement, E26N porphyry Cu-Au deposit, Goonumbla, New South Wales: Unpublished BSc (Hons) thesis, University of Queensland.

Harris, A. C., and Golding, S. D., 2002, New evidence of magmatic-fluid-related phyllic alteration: Implications for the genesis of porphyry Cu deposits: Geology, v. 30, p. 335-338.

Harris, A. C., and Holcombe, R. J., 2014, Quartz Vein Emplacement Mechanisms at the E26 Porphyry Cu-Au Deposit, New South Wales: Economic Geology, v. 109, p. 1035-1050.

Harrison, T. M., Duncan, I., and McDougall, I., 1985, Diffusion of ${ }^{40} \mathrm{Ar}$ in biotite: Temperature, pressure and compositional effects: Geochimica et Cosmochimica Acta, v. 49, p. 2461-2468.

Heithersay, P. S., 1991, The shoshonite-associated Endeavour 26 North porphyry copper-gold deposit, Goonumbla, NSW: Unpublished PhD thesis, Australian National University.

Heithersay, P. S., O'Neill, W. J., Van der Helder, P., Moore, C. R., and Harbon, P. G., 1990, Goonumbla porphyry copper district - Endeavour 26 North, Endeavour 22 and Endeavour 27, copper-gold deposits, in Hughes, F. E., ed., Geology of the Mineral Deposits of Australia and Papua New Guinea, Australasian Institute of Mining and Metallurgy Monograph 14, p. 1385-1398.

Heithersay, P. S., and Walshe, J. L., 1995, Endeavour 26 North: A porphyry copper-gold deposit in the Late Ordovician shoshonitic Goonumbla Volcanic Complex, New South Wales, Australia: Economic Geology, v. 90, p. 1506-1532.

Hendrawan, D., 2011a, The geology of GRP314: Unpublished Northparkes Mines report A735988.

Hendrawan, D., 2011b, The geology of the upper level of E48: Unpublished Northparkes Mines report A735995.

Hooper, B., Heithersay, P. S., Mills, M. B., Lindhorst, J. W., and Freyberg, J., 1996, Shoshonite-hosted endeavour 48 porphyry copper-gold deposit, Northparkes, central New South Wales: Australian Journal of Earth Sciences, v. 43, p. 279-288. 
House, M. J., 1994, Gold distribution at the E26 porphyry copper - gold deposit, N.S.W: Unpublished MEconGeol thesis, University of Tasmania.

Johnson, S. D., 2011, Factors influencing intrusive hosted porphyry Cu-Au mineralisation and REE fractionation at GRP314, Northparkes, New South Wales: Unpublished BSc (Hons) thesis, Monash University.

Jones, G. J., 1985, The Goonumbla Porphyry Copper Deposits, New South Wales: Economic Geology, v. 80, p. 591-613.

Keith, J. D., Christiansen, E. H., Maughan, D. T., and Waite, K. A., 1998, The role of mafic alkaline magmas in felsic porphyry $\mathrm{Cu}$ and Mo systems, in Lentz, D. R., ed., Mineralized Intrusion-related Skarn Systems, Mineralogical Association of Canada Short Course Series, 26, p. 211-243.

Kolkert, R., 1998, Carbonate-base metal veins peripheral to the Goonumbla porphyry Cu-Au deposits vectors to mineralised centres?: Unpublished BSc (Hons) thesis, University of Tasmania.

Krynen, J. P., Sherwin, L., and Clarke, I., 1990, Stratigraphy and structure, in Clarke, I., and Sherwin, L., eds., Geological Setting of Gold and Copper Mineralisation in the Parkes area, New South Wales, Records of the Geological Survey of New South Wales, 23, p. 1-76.

Le Maitre, R. W., Bateman, P., Dudek, A., Keller, J., Lameyre Le Bas, M. J., Sabine, P. A., Schmid, R., Sorensen, H., Streckeisen, A., Woolley, A. R., and Zanettin, B., 1989, A classification of igneous rocks and glossary of terms: Oxford, Blackwell.

Li, W., Jackson, S. E., Pearson, N. J., and Graham, S., 2010, Copper isotopic zonation in the Northparkes porphyry Cu-Au deposit, SE Australia: Geochimica et Cosmochimica Acta, v. 74, p. 4078-4096.

Lickfold, V., 2002, Intrusive history and volatile evolution of the Endeavour porphyry Cu-Au deposits, Goonumbla district, NSW, Australia: Unpublished PhD thesis, University of Tasmania.

Lickfold, V., Cooke, D. R., Crawford, A. J., and Fanning, C. M., 2007, Shoshonitic magmatism and the formation of the Northparkes porphyry $\mathrm{Cu}$ - Au deposits, New South Wales: Australian Journal of Earth Sciences, v. 54, p. 417-444.

Lickfold, V., Cooke, D. R., Smith, S. G., and Ullrich, T. D., 2003, Endeavour Copper-Gold Porphyry Deposits, Northparkes, New South Wales: Intrusive History and Fluid Evolution: Economic Geology, v. 98, p. 1607-1636.

Lye, A., 2006, The discovery history of the Northparkes deposits: SMEDG Mines and Wines Conference, Cessnock NSW, 2006.

McLean, A. L., Chapman, J., Sharpe, J. L., and Williams, P. A., 2004, The mineralogy of the oxidized zone of the E26 ore body at Northparkes, New South Wales: Australian Journal of Mineralogy, v. 10, p. 5358.

Middlemost, E. A. K., 1994, Naming materials in the magma/igneous rock system: Earth Science Reviews, v. 37 , p. 215-224.

Müller, D., Groves, D. I., and Heithersay, P. S., 1994, The shoshonite porphyry Cu-Au association in the Goonumbla District, N.S.W., Australia: Mineralogy and Petrology, v. 51, p. 299-321.

Owens, J., Priest, D., Jago, C., and Pacey, A., 2017, Northparkes copper-gold deposits, in Phillips, G.N., ed. Australian Ore Deposits, Australasian Institute of Mining and Metallurgy Monograph 32, p. 763770.

Percival, I. G., and Glen, R. A., 2007, Ordovician to earliest Silurian history of the Macquarie Arc, Lachlan Orogen, New South Wales: Australian Journal of Earth Sciences, v. 54, p. 143-165.

Perkins, C., McDougall, I., Claoue-Long, J., and Heithersay, P. S., 1990, ${ }^{40} \mathrm{Ar} /{ }^{39} \mathrm{Ar}$ and U-Pb Geochronology of the Goonumbla Porphyry Cu-Au Deposits, New South Wales, Australia: Economic Geology, v. 85, p. 1808-1824. 
Pickett, J. W., and Percival, I. G., 2001, Ordovician faunas and biostratigraphy at Gunningbland, central New South Wales: Alcheringa, v. 25, p. 9-52.

Putnis, A., Hinrichs, R., Putnis, C. V., Golla-Schindler, U., and Collins, L. G., 2007, Hematite in porous redclouded feldspars: Evidence of large-scale crustal fluid-rock interaction: Lithos, v. 95, p. 10-18.

Radclyffe, D., 1995, Regional-scale propylitic alteration in the Goonumbla mineral field, Parkes, NSW: Unpublished BSc (Hons) thesis, University of Tasmania.

Rickwood, P. C., 1989, Boundry lines within petrologic diagrams which use oxides of major and minor elements: Lithos, v. 22, p. 247-263.

Scheibner, E., 1993, Structural framework of New South Wales - synthesis: Geological Survey of New South Wales Quarterly Notes, v. 93, p. 1-36.

Scheibner, E., and Basden H. ed. 1998. Geology of New South Wales - Synthesis. Volume 2 Geological Evolution. Geological Survey of New South Wales, Memoir Geology 13(2), 666 p.

Sherwin, L., 1979, Age of the Nelungaloo Volcanics, near Parkes: Quarterly Notes of the Geological Survey of New South Wales, v. 35, p. 15-18.

Sherwin, L., 1996, Narromine 1:250,000 Geological Sheet SI/55-3: Explanatory Notes, Geological Survey of New South Wales, Sydney, p. 104.

Sherwin, L., 2000, Yarrimbah Formation, in Lyons, P., Raymond, O. L., and Duggan, M. B., eds., Forbes 1:250,000 Geological Sheet SI/55-7 (2nd edition) Explanatory Notes, Geological Survey of New South Wales, Sydney, p. 30.

Simpson, C. J., Cas, R. A. F., and Arundell, M. C., 2005, Volcanic evolution of a long-lived Ordovician islandarc province in the Parkes region of the Lachlan Fold Belt, southeastern Australia: Australian Journal of Earth Sciences, v. 52, p. 863-886.

Squires, V. E., 1992, The mineralisation and alteration of the Endeavour 27 porphyry copper - gold deposit, Goonumbla, New South Wales: Unpublished BSc (Hons) thesis, University of Sydney.

Stanley, C.R., and Madeisky, H.E., 1996, Lithogeochemical Exploration for Metasomatic Zones Associated with Hydrothermal Mineral Deposits Using Pearce Element Ratio Analysis, Mineral Deposit Research Unit, University of British Columnbia, Vancouver, Canda, short coarse notes January 1996, 98 .

Sun, S.-s., and McDonough, W. F., 1989, Chemical and isotopic systematics of oceanic basalts: implications for mantle composition and processes: Geological Society of London, Special Publication, v. 42, p. 313-345.

Webby, B. D., Paris, F., Droser, M. L., and Percival, I. G., 2004, The Great Ordovician Biodiversity Event: New York, Columbia University Press, $496 \mathrm{p}$.

Wolfe, R. C., 1994, The Geology, paragenesis and alteration geochemistry of the Endeavour $48 \mathrm{Cu}-\mathrm{Au}$ porphyry, Goonumbla NSW: Unpublished BSc (Hons) thesis, University of Tasmania.

Wolfe, R. C., 1996, A magmatic origin for late-stage sericite-alunite alteration at the Endeavour $48 \mathrm{Cu}-\mathrm{Au}$ porphyry deposit, Goonumbla, NSW: Geological Society of Australia Abstracts, v. 41, p. 480. 


\section{Figure Captions}

\section{Figure 1}

Map showing the location of Northparkes and other porphyry deposits hosted within Ordovician age volcanic belts, as labelled, which constitute the Macquarie Arc in New South Wales. Outcrop of volcanic belts partly interpreted from aeromagnetic data; modified from Scheibner and Basden (1998) and Glen and Walshe (1999), after Lickfold (2002). Inset shows extent of the map within Australia.

\section{Figure 2}

Red quartz monzonite porphyry emplaced into dark trachyandesite volcanics; exposed in the E27 open pit.

\section{Figure 3}

Geological map of the Northparkes region (area shown in Figure 1). Adapted from Simpson et al. (2005) and Arundell (1997), after Krynen et al. (1990) and Heithersay et al. (1990). Note all contacts are inferred owing to thick cover; dashed contacts to monzonitic intrusions reflect disagreement between authors on their exact position. Ages for intrusions are from Butera et al. (2001), after Simpson et al. (2005). Gravity anomaly from Northparkes Mines ground survey. Coordinates are in meters with respect to GDA94 MGA Zone 55.

\section{Figure 4}

Geological plan of the E26, E48 and GRP314 deposits, below the level of the Altona Fault ( 780 m below surface); area annotated on Figure 3. Lines of section indicated through E26 and E48 are provided as Figures 5 and 6 respectively. Geological detail is from Northparkes Mines, constrained by the entire drill core database and gravity modelling. Alteration detail is based both on the overall drill core database model and detailed logging of diamond drillholes as part of this study (Figs. 18 and 19), the paths of which are indicated and show 100 m markings.

\section{Figure 5}

Cross section through the E26 deposit; color scheme and details as for Figure 4. Porphyry bodies are interpretively projected onto the section (unless indicated) to match all known occurrences in the plane of the section: this avoids them appearing as discontinuous lenses. For clarity, details of volcanic country rock facies are omitted, however examples are provided in Figure 9. Alteration minerals: $A b=a l b i t e ; B n=$ bornite; $\mathrm{Bt}=$ biotite; $\mathrm{Ccp}=$ chalcopyrite; $\mathrm{Chl}=$ chlorite; $\mathrm{Epi}=$ epidote; Hem = hematite; $\mathrm{Kfs}=\mathrm{K}$-feldspar; $\mathrm{Mag}$ = magnetite; Py = pyrite; Qtz = quartz.

\section{Figure 6}

Cross section through the E48 deposit; color scheme and details as for Figure 4. Porphyry bodies are projected as for Figure 5.

\section{Figure 7}

Summary of geochronological data, listed from bottom to top in relative order of formation. Color of age bars corresponds to the dating method. Also shown is the deposition interval of the Billabong Creek Limestone-Gunningbland Formation from Pickett and Percival (2001), after Percival and Glen (2007). The Ordovician-Silurian boundary shown is that of Cohen et al. (2013).

\section{Figure 8}

$\mathrm{Rb}-\mathrm{Sr}$ isochron plot for both whole rock samples and epidote separates from propylitic alteration around the E48 deposit. Note the mean square weighted deviation (MSWD) = 13 for the proposed 'isochron' shown.

\section{Figure 9}

Semi-schematic scaled cross section to illustrate the occurrence, form and relationships between major lithologies at Northparkes; based off a NE-trending cross section through E26.

\section{Figure 10}


Volcanic and volcaniclastic lithologies at Northparkes; all scale bars $=1 \mathrm{~cm}$. (a) plagioclase-pyroxene-phyric trachyandesite, GD654/729 m; (b) chloritized hyaloclastic breccia on the surface of a trachyandesite unit, E34D3/277 m; (c) rare laminations between grey mudstone and chloritized siltstone, deposited on a coarser crystal-bearing sandstone, E48D134/385 m; (d) welded, trachytic lithic-crystal ignimbrite showing red trachyte, central trachyandesite and possible wispy pumice clasts, in fine banded matrix containing plagioclase, K-feldspar and pyroxene crystals, E26D459/134 m.

\section{Figure 11}

The principal plutonic rocks at Northparkes; all scale bars $=1 \mathrm{~cm}$. (a) pre-mineralization monzodiorite xenolith in the BQM pluton, CND5/641 m; (b) equigranular end-member of the BQM, from an area lacking hematite reddening, E26D460/950 m; (c) weakly porphyritic BQM with subhedral, weakly sericitized plagioclase and smaller K-feldspar and chloritized biotite crystals in a hematite reddened groundmass of Kfeldspar and quartz, E48D147/359 m; (d) AFG to quartz alkali feldspar syenite, large weakly sericitized plagioclase and chloritized biotite crystals are surrounded by interlocking K-feldspar with interstitial, anhedral quartz, E26D361/ $341 \mathrm{~m}$; (e) QMZ with characteristic anhedral plagioclase and quartz, but euhedral K-feldspar, in groundmass containing much granular anhedral quartz and K-feldspar; disseminated chalcopyrite throughout, E26D467/440 m; (f) K-feldspar megacryst poikilitically enclosing plagioclase in strongly porphyritic QMZ, BZD10/ 600 $\mathrm{m}$.

\section{Figure 12}

Quartz monzonite and monzonite porphyries at Northparkes, note the high degree of crystal crowding; all scale bars $=1 \mathrm{~cm}$. (a) K-feldspar QMP with glassy groundmass and broken, angular K-feldspar phenocryst, E48D147/255 m; (b) syn- to late-mineralization porphyry, with notable mafic biotite and augite phenocrysts as well as both broken, angular and euhedral K-feldspar phenocrysts, E26D497/ 360 m; (c) latemineralization QMP with biotite as the mafic phase; note xenoliths of quartz-veined BQM and complex zoning of K-feldspar that forms a euhedral outer pink overgrowth on earlier irregular (partly resorbed?) grey K-feldspar crystals, K-feldspar also overgrows some plagioclase, BZD32/ 770 m; (d) enlarged view of zoned K-feldspar crystal in QMP, showing an initial subhedral grey crystal overgrown by euhedral pink Kfeldspar, which poikilitically encloses plagioclase; bornite and chalcopyrite specks are trapped at the contact, E26D545/ 630 m; (e) typical texture and coloration of the zero porphyry phase, E26D459/377 m; (f) irregular-shaped xenoliths of dark brown basaltic trachyandesite within the reddish brown zero porphyry, note epidote veinlets (P3) that are associated with propylitic alteration, E26D440/223 m; (g) typical texture and coloration of the post-mineralization monzonite porphyry at E34, E34D3/849 m.

\section{Figure 13}

Breccias and magmatic-hydrothermal features at Northparkes; all scale bars $=1 \mathrm{~cm}$. (a) irregular blebs and patches of K-feldspar and aplite surrounded by quartz with bornite and chalcopyrite in QMP, E26D467/204 m; (b) UST comprising chalcopyrite, fluorite and anhydrite on sericitically-altered aplitic QMP substrate, followed by a comb quartz layer and further aplitic QMP, growth direction inferred from top right to bottom left, E26D507/1062 m; (c) anhydrite intergrown with bladed biotite, E26D544/446 m; (d) pebble dike with rounded clasts of trachyandesite (AND), BQM, AFG and quartz-sericite-altered vein fill with chalcopyrite, E26D411/249 m; (e) jigsaw-fit breccia of strongly biotite-magnetite altered trachyandesite clasts (containing truncated quartz-bornite K2 veinlets and a K1 vein with strong magnetite-biotite halo); aplite QMP cement contains occasional plagioclase phenocrysts and segregations/miarolitic cavities of interlocking quartz-K-feldspar-bornite, E27 open pit; (f) bornite-K-feldspar-quartz-cemented stockwork breccia containing clasts of quartz and strongly potassically-altered host rock, E27; (g) euhedral K-feldspar crystals within bornite, from the same block in (f); (h) intrusive breccia with fragments of dark trachyandesite, BQM, light-colored sericitized rock and a propylitic P1 vein (top left comprized of chloritequartz-calcite-pyrite-hematite), cemented by a post-mineralization monzonite porphyry (Fig. 12g) at E34, E34D3/779 m; (i) the highly undulate contact of the porphyry unit in (h) and Figure $12 \mathrm{~g}$ with surrounding country rock, which is now a fine chloritized rock flour breccia, E34D3/677 m; (j) with increasing distance from the intrusion, the breccia of (i) contains larger clasts, here of trachyandesite (AND), BQM and quartz veins in fine chloritized and quartz-calcite-pyrite-cemented rock flour matrix - a texture identical to the 
pebble dikes observed elsewhere, E34D3/680 m; (k) irregular bornite clot in QMP, bornite encloses Kfeldspar and shows minor chalcopyrite on its margins, E22D279/449 m.

\section{Figure 14}

Major, minor and selected trace element geochemistry of country rock volcanics, as indicated in the legend. (a) total alkali vs. silica classification, $\mathrm{TB}=$ trachybasalt, $\mathrm{BTA}=$ basaltic trachyandesite, $\mathrm{TA}=$ trachyandesite, TR = trachyte, fields after Le Maitre et al. (1989); (b-o) Harker variation plots for elements as indicated, division of subalkalic rocks in (b) is after the summary of Rickwood (1989). Note 224 available analyses are plotted on $(a-j)$, numbers of available analyses for plots $(k-0)$ is variable and shown separately as $n=x$. Trachyandesites are shown separately as they occur in both the Goonumbla and Wombin Volcanics.

\section{Figure 15}

N-MORB normalized REE plots for (a-c) country rock volcanic packages and (d) trachyandesites; number of samples shown as $n=x$. Normalising values from Sun and McDonough (1989).

\section{Figure 16}

Major, minor and selected trace element geochemistry of Northparkes intrusive rocks, as indicated in the legend; $\mathrm{BQM}=$ biotite quartz monzonite, $\mathrm{AFG}=$ alkali feldspar granite, $\mathrm{QMZ}=$ quartz monzonite, $\mathrm{QMP}=$ quartz monzonite porphyry. (a) total alkali vs. silica classification, $A B=$ alkali basalt, $M G=$ monzogabbro, $\mathrm{MD}=$ monzodiorite, $\mathrm{GD}=$ gabbroic diorite, $\mathrm{MO}=$ monzonite, $\mathrm{QM}=$ quartz monzonite, fields after Middlemost (1994); (b-q) Harker variation plots for elements as shown, division of subalkalic rocks in (b) is after summary of Rickwood (1989). Note 225 analyses are plotted on (a-j), numbers of available analyses for plots $(k-q)$ is variable and shown separately as $n=x$.

\section{Figure 17}

N-MORB normalized REE plots for Northparkes intrusive rocks, as indicated. Presented from (a) to (f) in order of emplacement; number of samples shown as $n=x$. Normalising values from Sun and McDonough (1989).

\section{Figure 18}

Lithology and alteration logs for selected diamond drillholes around E26, depth in meters from collar. Drillhole positions shown on Figures 4 and 5. The division of alteration zones is based on the logged mineralogy. Lithological codes: $A F G=$ alkali feldspar granite; $A N D=$ trachyandesite; $B Q M=$ biotite quartz monzonite; $\mathrm{CON}=$ volcanic conglomerate; $\mathrm{HBX}=$ hydrothermal breccia (veins and pebble dikes); $\mathrm{IBX}=$ intrusion-cemented breccias; $\mathrm{MPOR}=$ monzonite porphyry; $\mathrm{MZO}=$ mafic zero monzonite porphyry; $\mathrm{QMP}=$ quartz monzonite porphyry; $\mathrm{QMZ}=$ quartz monzonite; $\mathrm{SST}=$ volcanic sandstone; $\mathrm{TBX}=$ autoclastic trachyte breccia; TR = trachyte; TRS = trachytic sill; TVB = trachytic volcanic breccia/ignimbrite; ZRO = zero monzonite porphyry.

\section{Figure 19}

Lithology and alteration logs for selected diamond drillholes around E48, including E34, depth in meters from collar. Drillhole positions are shown on Figures 4 and 6 . All details as defined in Figure 18. Alteration zones indicated where appropriate; sericitic alteration at the base of E48D134 is part of the sericite-albitequartz-alunite \pm chlorite overprint to the core of E48. Other sericitic alteration is spatially associated with faults.

\section{Figure 20}

Schematic diagram illustrating the spatial distribution of vein types, as well as their relationship to each other, major alteration facies and QMP intrusions at Northparkes. The vein density shown approximates the relative changes observed. Veins associated with particular alteration facies are mostly spatially restricted to that zone, and are numbered with respect to their paragenesis within it, e.g. K1 to K3 for potassic veins. The latest gypsum-anhydrite veins and calcite veins are omitted. Note the barren quartz veins, sericitic veins and anhydrite-quartz veins are not necessarily present in all the Northparkes deposits. 


\section{Figure 21}

Potassium silicate alteration and principal associated vein types; all scale bars $=1 \mathrm{~cm}$. (a) $\mathrm{K} 1$ quartz veinlet with biotite halo developed in trachyte, E48D134/857 m; (b) network of K2 quartz-K-feldspar-bornite veinlets surrounded by K-feldspar alteration halos and biotite spots within trachytic ignimbrite, E26D459/5 m; (c) K3 quartz-bornite \pm chalcopyrite stockwork cutting K-feldspar veinlets (K2) in biotite altered trachyandesite, E48D163/ 400 m; (d) two generations of quartz-bornite (K3) veins in K-feldspar-rich QMP, note increased width of K-feldspar alteration halos compared to (c), E48D134/92 m; (e) original stockwork of $\mathrm{K} 3$ veins in AFG, pervasively overprinted by sericite-albite-quartz-alunite alteration; E48D134/ 900 m; (f) $\mathrm{K} 3$ vein with thin K-feldspar halo cutting irregular magnetite veinlet (M1) in magnetite-biotite altered trachyandesite, E48D134/657 m; (g) examples showing the effect of fine disseminated magnetite-biotite alteration on original trachytic ignimbrite, from least altered (left) to most altered (right), E26SD107, 498$545 \mathrm{~m}$; (h) magnetite-biotite clots in BQM, surrounded by weak K-feldspar alteration of groundmass and sericitic clouding of plagioclase - the typical appearance of BQM within the magnetite-biotite alteration shell, E26D507/735 m.

\section{Figure 22}

Propylitic alteration and principal vein types; all scale bars $=1 \mathrm{~cm}$. (a) volcanic sandstone with epidotechlorite spots developed around clasts, in chloritized matrix with disseminated pyrite, E48D134/413 m; (b) P3 epidote veinlet cutting a siltstone bed in volcanic sandstone, note fluid was forced away from the vein at the lithological contact, E48D134/445 m; (c) epidote-quartz patches surrounded by chlorite halos, developed in trachyandesite, GD654/483 m; (d-f) relatively small P1 veins with zoned alteration halos: (d) truncated by E34 monzonite porphyry, E34D3/759 m, (e) in trachyandesite, E34D3/644 m, (f) in BQM, E48D147/473 $\mathrm{m}$; $(\mathrm{g})$ examples of alteration transitions associated with large $\mathrm{P} 1$ veins in $\mathrm{BQM}$, left = chlorite-quartz-calcite-hematite-pyrite vein fill, middle left $=$ vein-proximal chlorite-sericite (phengitic)quartz-epidote alteration, middle right $=$ hematite-sericite-chlorite alteration, right $=$ most vein-distal hematite reddening of pre-existing K-feldspar with minor albitization of plagioclase and chlorite-epidote developed around original biotite, E48D147, 499-782 m; (h-k) P2 veins with distinct zoned chlorite-epidotealbite-hematite halos described in text: (h) in BQM, E48D147/630 m, (i) in fine volcanic sandstone, E34D3/1216 m, (j) inwards growth of epidote from vein margins into quartz, re-fractured by calcite and fringed by chlorite-pyrite-epidote, in trachyandesite, GD654/297 m, (k) rare anhydrite and K-feldspar in vein center, E34D3/ 1216 m; (I,m) P3 epidote veinlets with irregular blebby margins fringed by hematite reddened albite: (I) in trachyandesite, E48D134/216 m, $(\mathrm{m})$ in volcanic conglomerate, E26D361/739 $\mathrm{m}$; (n) pebble dike containing epidote fragments and truncating epidote veinlet (P3), GD654/346 m; (o) epidotealbite-hematite alteration occurring within, and radiating from, a pebble dike, unknown drillhole.

\section{Figure 23}

Spatial variation of sericitic veins; all scale bars $=1 \mathrm{~cm}$. Quartz-sericite \pm pyrite alteration is consistently developed proximal to the vein centres, which are filled by quartz and/or anhydrite, but the vein-distal alteration assemblage is variable. Generally, samples closest to E26 $(\mathbf{a}, \mathbf{b})$ show outermost K-feldspar \pm biotite alteration. With increasing distance from the deposit this diminishes (c) and weak (d) to ultimately strong $(\mathbf{e}, \mathbf{f})$ chlorite-sericite alteration forms instead. In most deposit-distal locations, epidote and hematite may also be present, giving a propylititc assembladge (g,h). Details: (a) large example in BQM with quartzpyrite-anhydrite fill and strong outer K-feldspar-biotite development, E26D507/1070 m, (b) in volcanic conglomerate with chalcopyrite-quartz-anhydrite fill, E26D459/83 m, (c) in volcanic conglomerate with anhydrite-chalcopyrite-pyrite fill, E26D459/5 m, (d) in BQM with pyrite-anhydrite-quartz fill, E26D507/643 $\mathrm{m}$, (e) in BQM with anhydrite fill, E26D507/630 m, (f) in BQM with quartz-anhydrite fill, cut by gypsumanhydrite veins, E26D507/362 m, (g) in BQM with anhydrite-quartz-pyrite fill and fine epidote in outermost halo, E26D507/385 m, (h) in BQM with distinct green epidote in outer hematite reddened halo, center reopened by gypsum-anhydrite vein, E26D507/385 m.

\section{Figure 24}

Examples of the base metal, anhydrite-quartz and gypsum-anhydrite veins; all scale bars $=1 \mathrm{~cm}$. $(\mathbf{a}, \mathbf{b})$ quartz-sphalerite base metal veins: (a) with pyrite in brecciated quartz, cemented by late barren calcite, E26D361/643 m, (b) reopening a P1 propylitic vein, E48D147/501 m; (c) anhydrite appearing to form a 
breccia cement within K-feldspar-biotite altered BQM, likely recording fluid escape and recording the potential origin of the anhydrite-quartz veins, E26D510/178 m; (d) anhydrite-quartz vein, showing comb quartz growth, with strong surrounding K-feldspar-biotite alteration in BQM, E26D507/1128 m; (e-h) anhydrite-quartz veins with limited sericitic halos: (e) with pyrite and chalcopyrite, brecciating and reopening a sericitic vein, E26D460/237 m, (f) with pyrite and chalcopyrite, cutting the strongly quartzsericite-pyrite altered halo of a sericitic vein, still, a secondary sericite-quartz halo can be observed, E26D460/304 m, (g) with molybdenite and chalcopyrite cementing brecciated quartz-sericite altered fragments of a large sericitic vein, the fragments contain most of the molybdenite and are probably the source of molybdenum in the anhydrite, E26D460/240 m, (h) with sphalerite, chalcopyrite, pyrite and anhydrite, E26D507/461 m; (i) barren anhydrite-gypsum vein cutting P3 epidote veinlets in BQM, E26D507/276 m. 
Figure 1

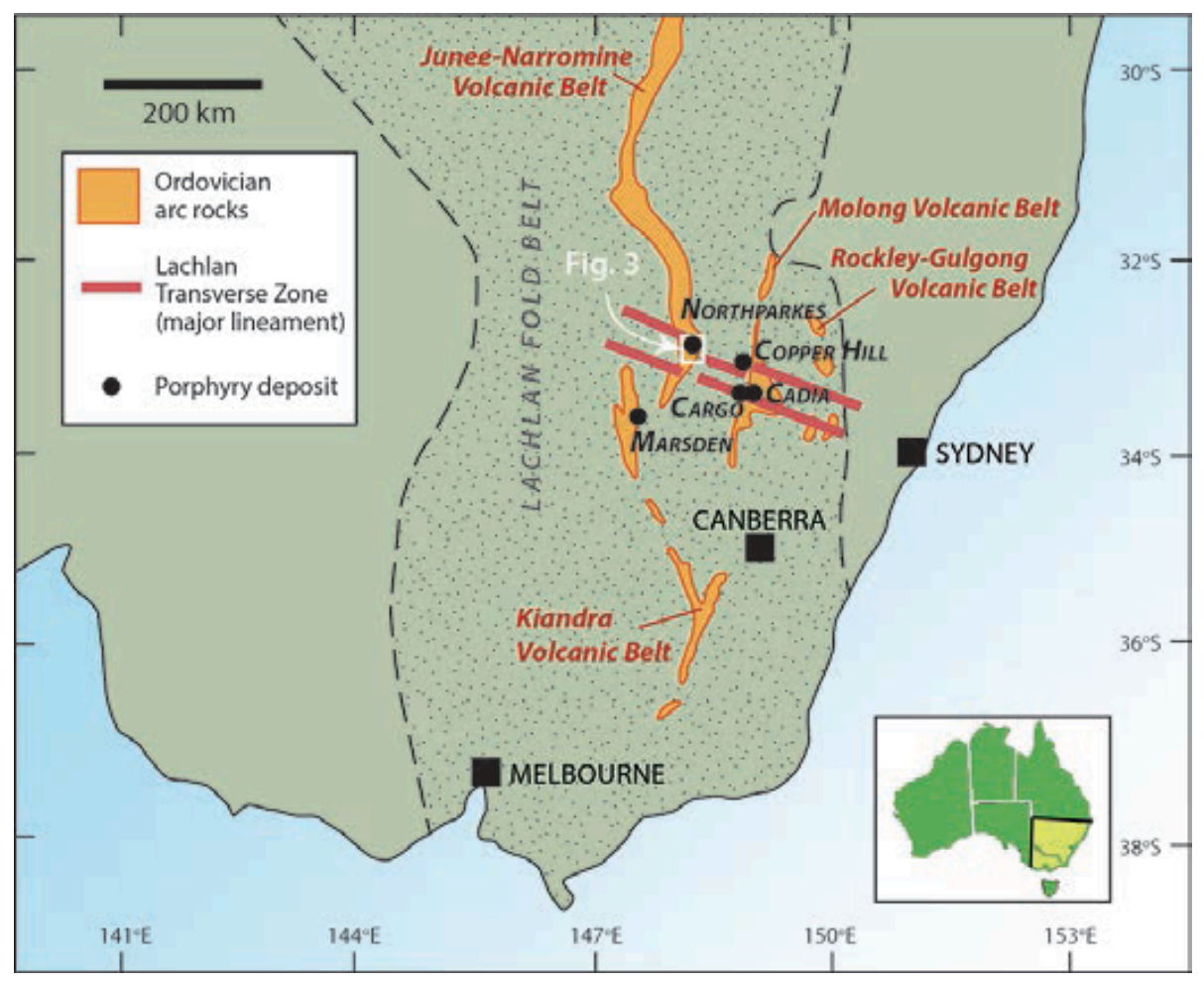


Figure 2

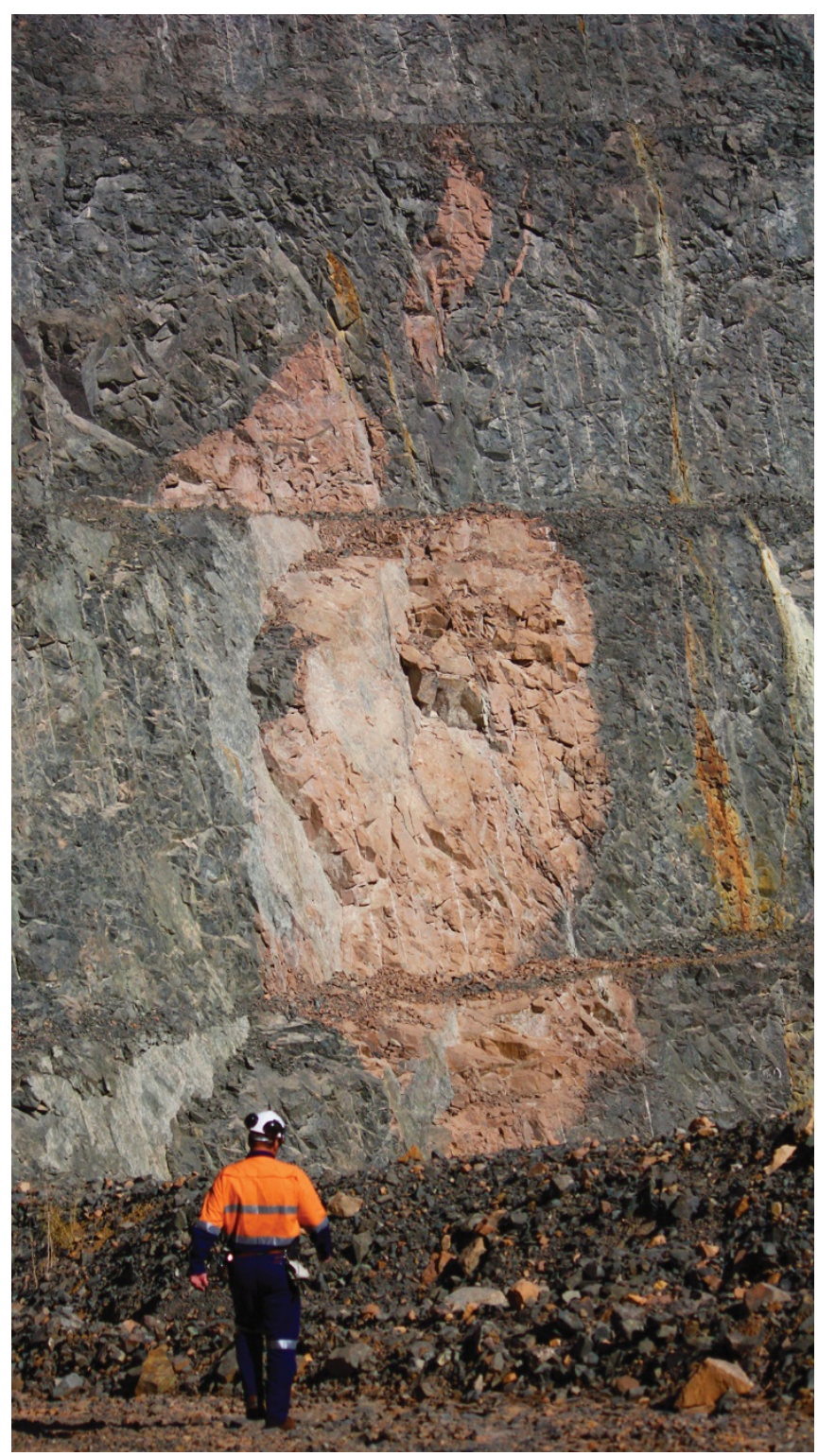


Figure 3

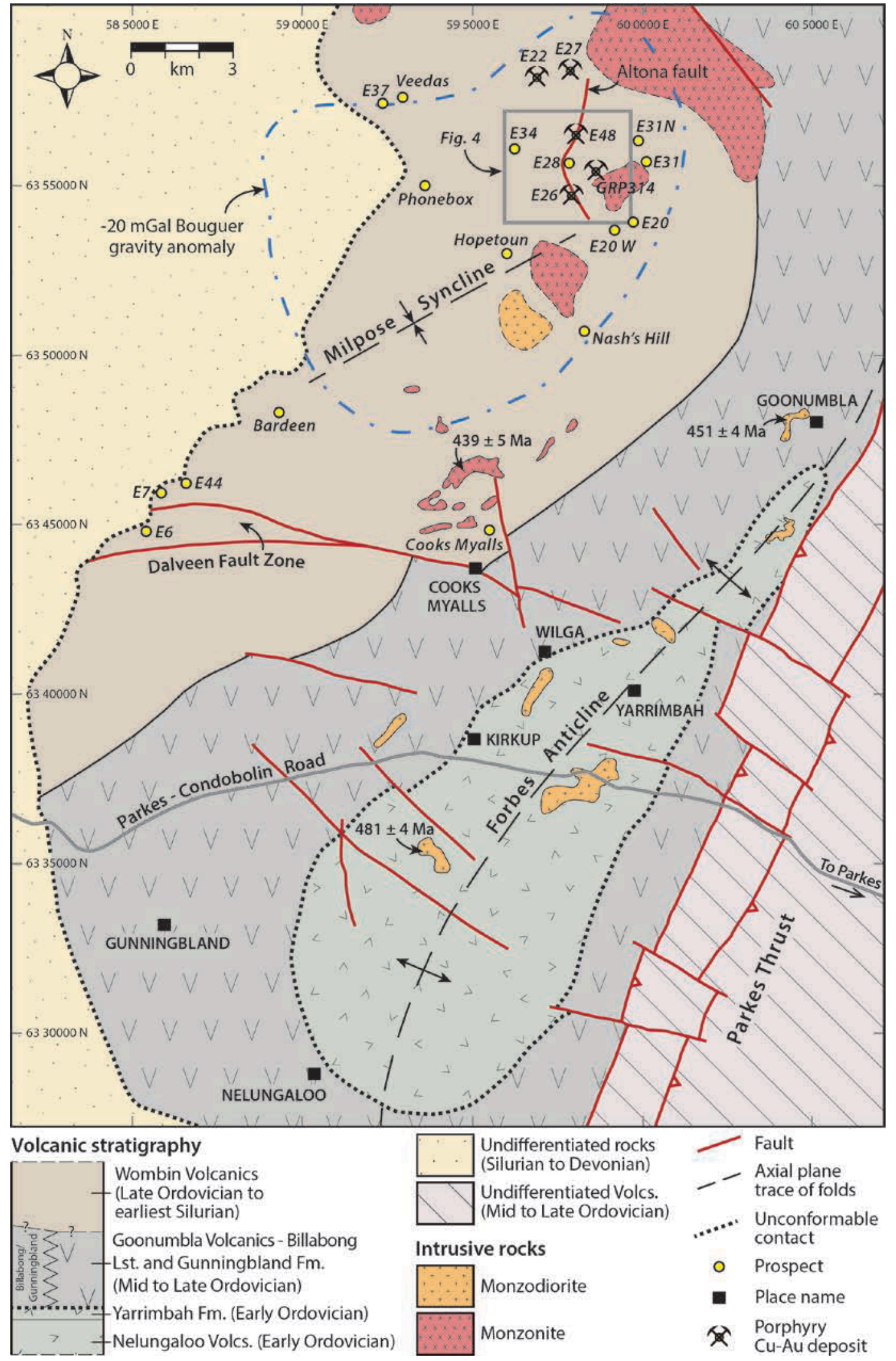


Figure 4

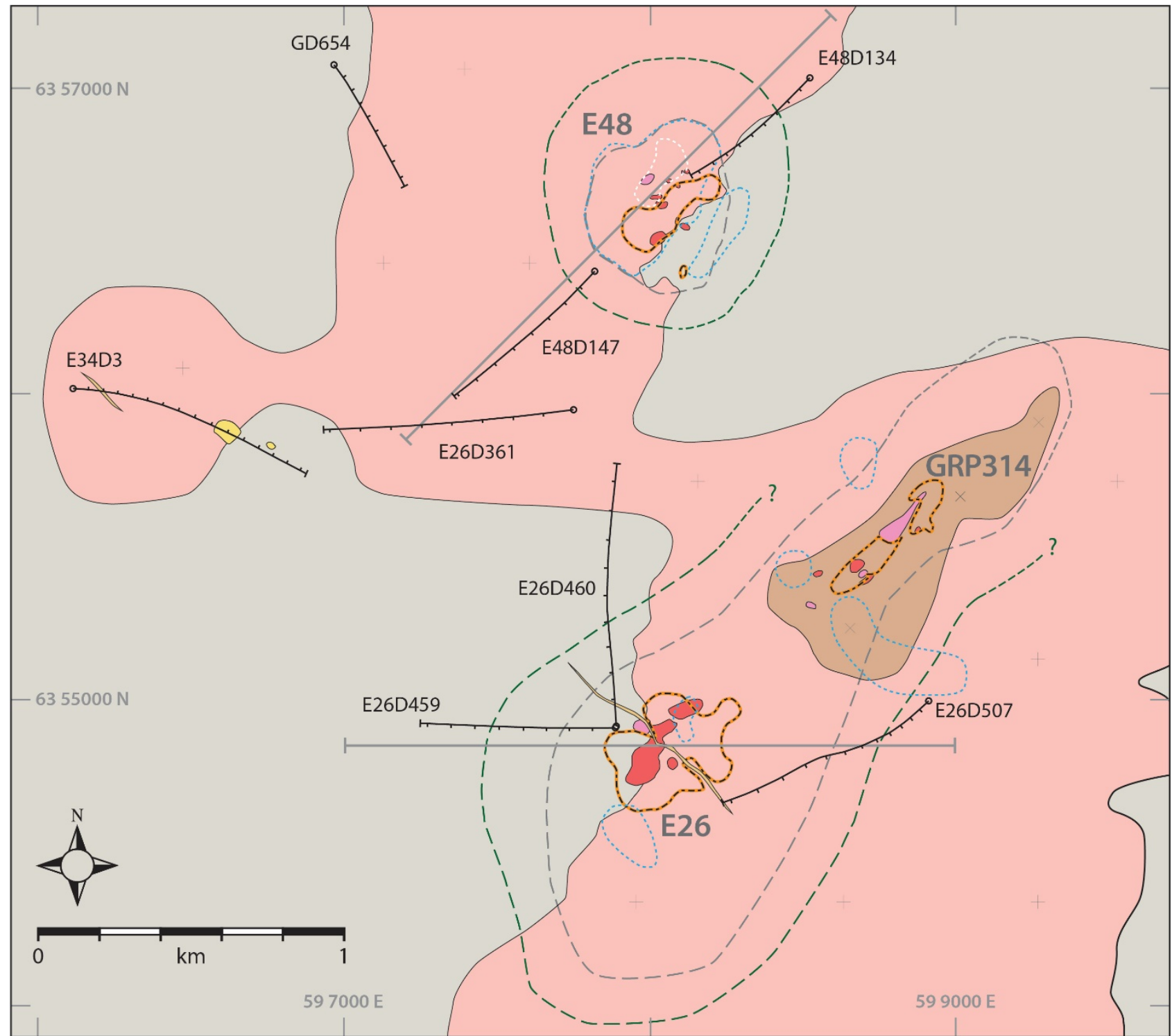

Country rock volcanics

Biotite quartz monzonite to alkali feldspar granite pluton

\section{Quartz monzonite}

Early- and syn-mineralization quartz monzonite porphyries

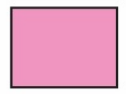

Late-mineralization quartz monzonite porphyries

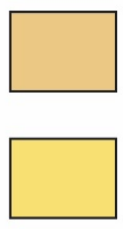

Post-mineralization 'zero' monzonite porphyry; as dikes

\section{Post-mineralization} monzonite porphyry

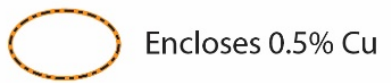

Encloses zones of sericitic (blue) and albite-sericitechlorite (white) alteration

Encloses zones of potassic, K-feldspar alteration

Separates deposit proximal magnetite-biotite alteration from distal propylitic (epidotechlorite-albite) alteration 


\section{Figure 5}

$597000 \mathrm{E}$
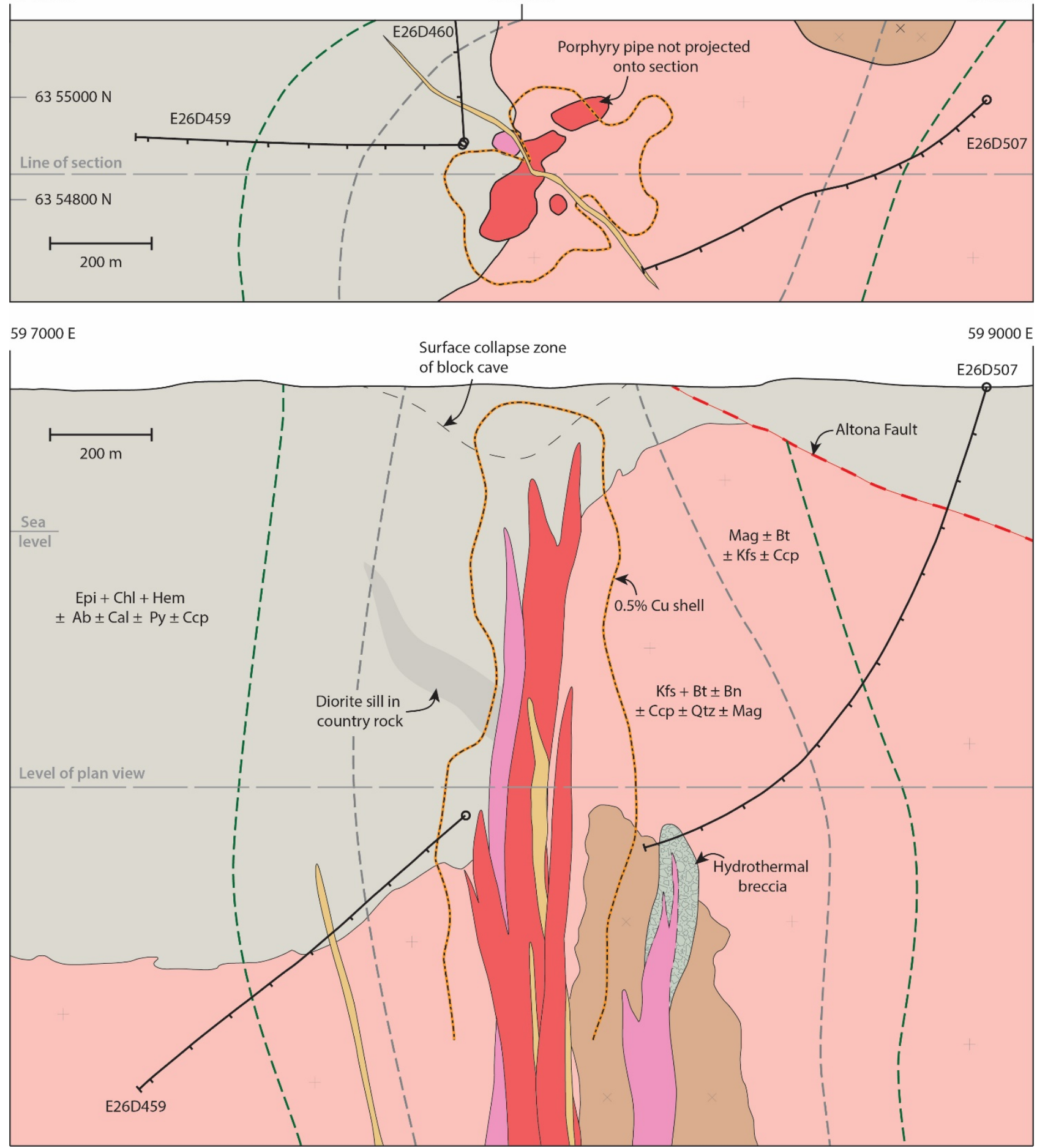


\section{Figure 6}

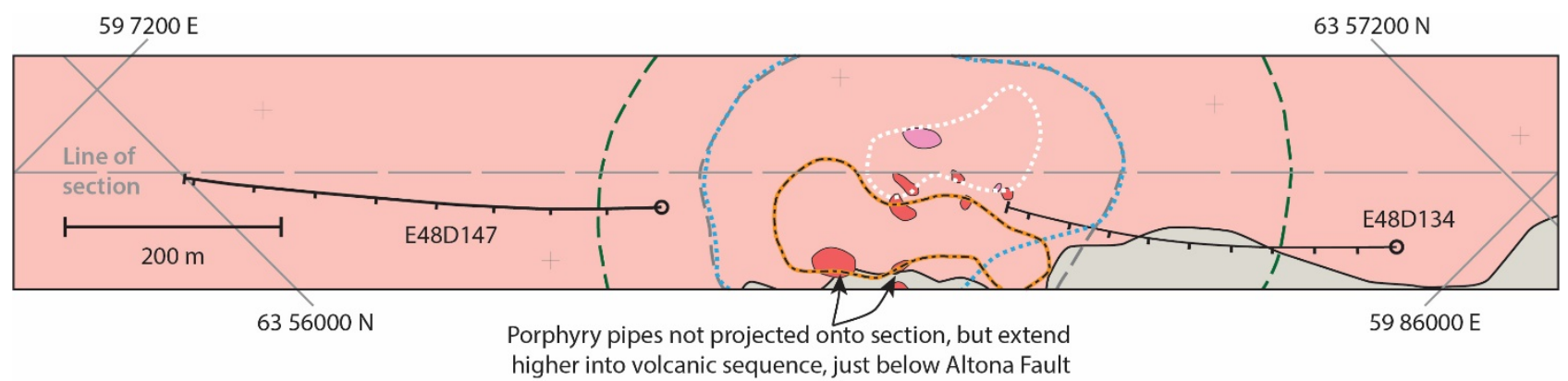

597200 E

$598600 \mathrm{E}$

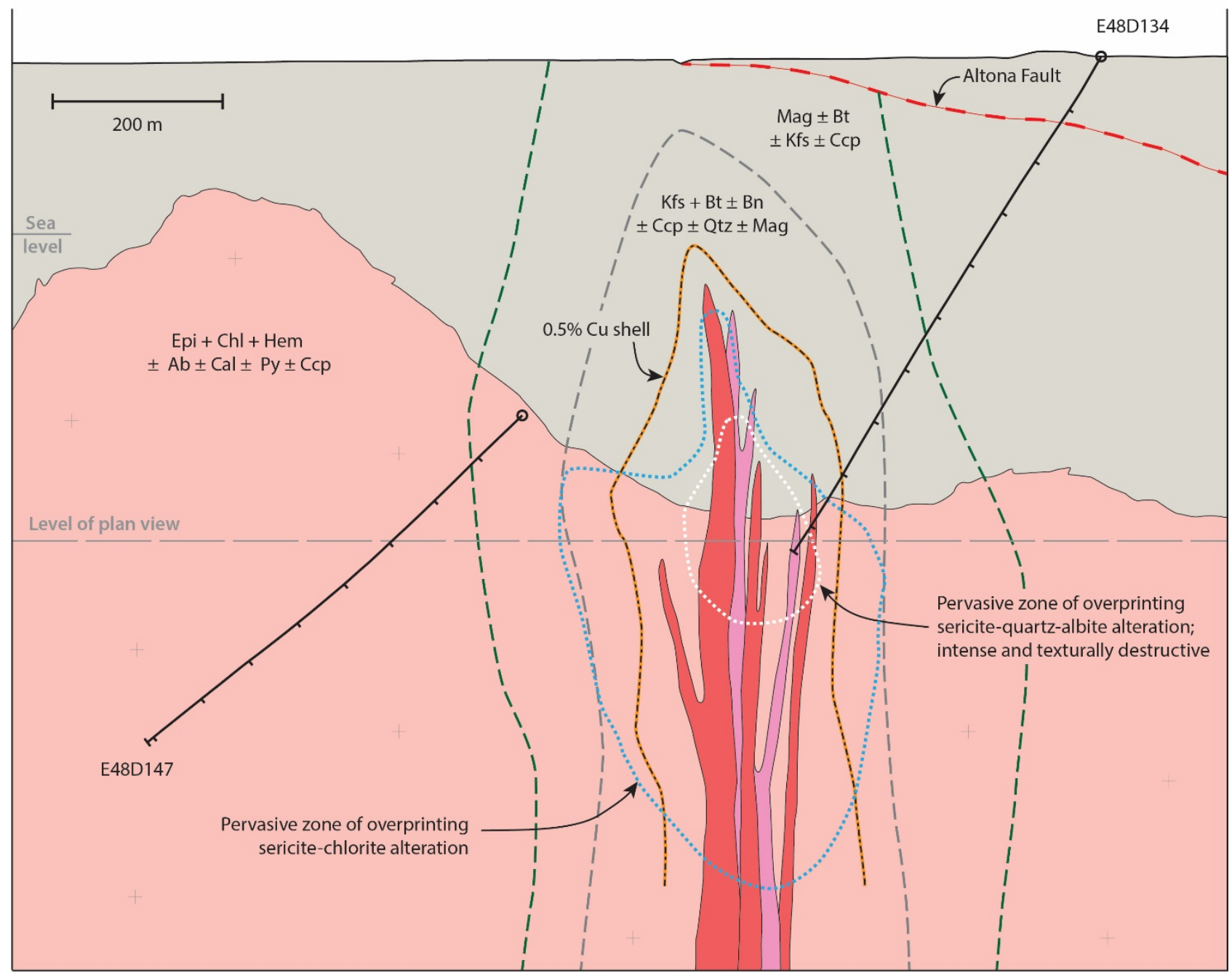


Figure 7

\begin{tabular}{|c|c|c|c|c|c|c|}
\hline 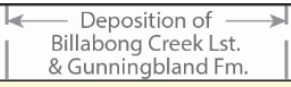 & Ordovician & $\overrightarrow{\text { Silurian }}$ & Date of: & Method & Result (Ma) & Reference \\
\hline $\mid \begin{array}{l}\text { Late-to post- } \\
\text { mineralization }\end{array}$ & & 1 & Zero porphyry (E37) & $\begin{array}{l}\text { Zircon U-Pb } \\
\text { (SHRIMP) }\end{array}$ & $436.7 \pm 3.3$ & Lickfold et al. (2007) \\
\hline | & 1 & & (Biotite) QMP (E22) & Biotite $\mathrm{Ar} / \mathrm{Ar}$ & $446.5 \pm 2.6$ & Lickfold et al. (2003) \\
\hline $\begin{array}{l}\text { Mineralization } \\
\text { generated }\end{array}$ & & 十 & Sericitic alteration (E26) & Sericite $\mathrm{Ar} / \mathrm{Ar}$ & $439.2 \pm 1.2$ & Perkins et al. (1990) \\
\hline & & & Propylitic alteration (E48?) & $\begin{array}{l}\text { Epidote and } \\
\text { whole rock Rb-Sr }\end{array}$ & $450 \pm 11$ & This study \\
\hline | & & H & Biotite alteration (E26) & Biotite $\mathrm{Ar} / \mathrm{Ar}$ & $441.3 \pm 3.8$ & Lickfold et al. (2003) \\
\hline & $t$ & & (Biotite) QMP (E26) & Biotite $\mathrm{Ar} / \mathrm{Ar}$ & $448.6 \pm 7.0$ & Lickfold et al. (2003) \\
\hline & & & BQM (E26) & $\begin{array}{l}\text { Zircon U-Pb } \\
\text { (SHRIMP) }\end{array}$ & $444.2 \pm 4.7$ & Lickfold et al. (2007) \\
\hline $\begin{array}{l}\text { Pre- to early- } \\
\text { mineralization }\end{array}$ & & 1 & BQM (E26) & Biotite $\mathrm{Ar} / \mathrm{Ar}$ & $437.3 \pm 2.1$ & Lickfold et al. (2003) \\
\hline \begin{tabular}{l|l}
1 & 1 \\
460
\end{tabular} & 450 & 440 & & & & \\
\hline
\end{tabular}

\section{Figure 8}

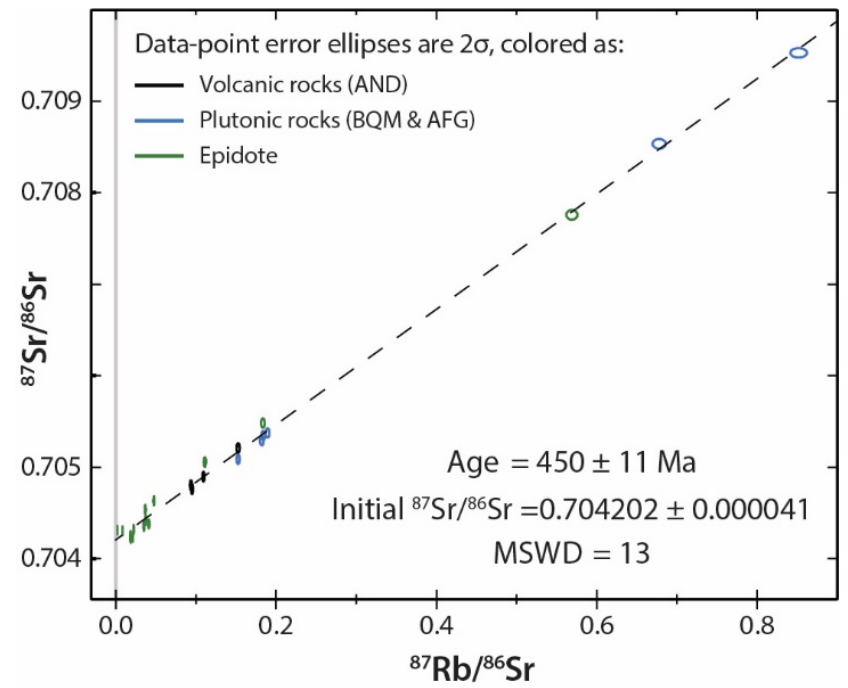




\section{Figure 9}

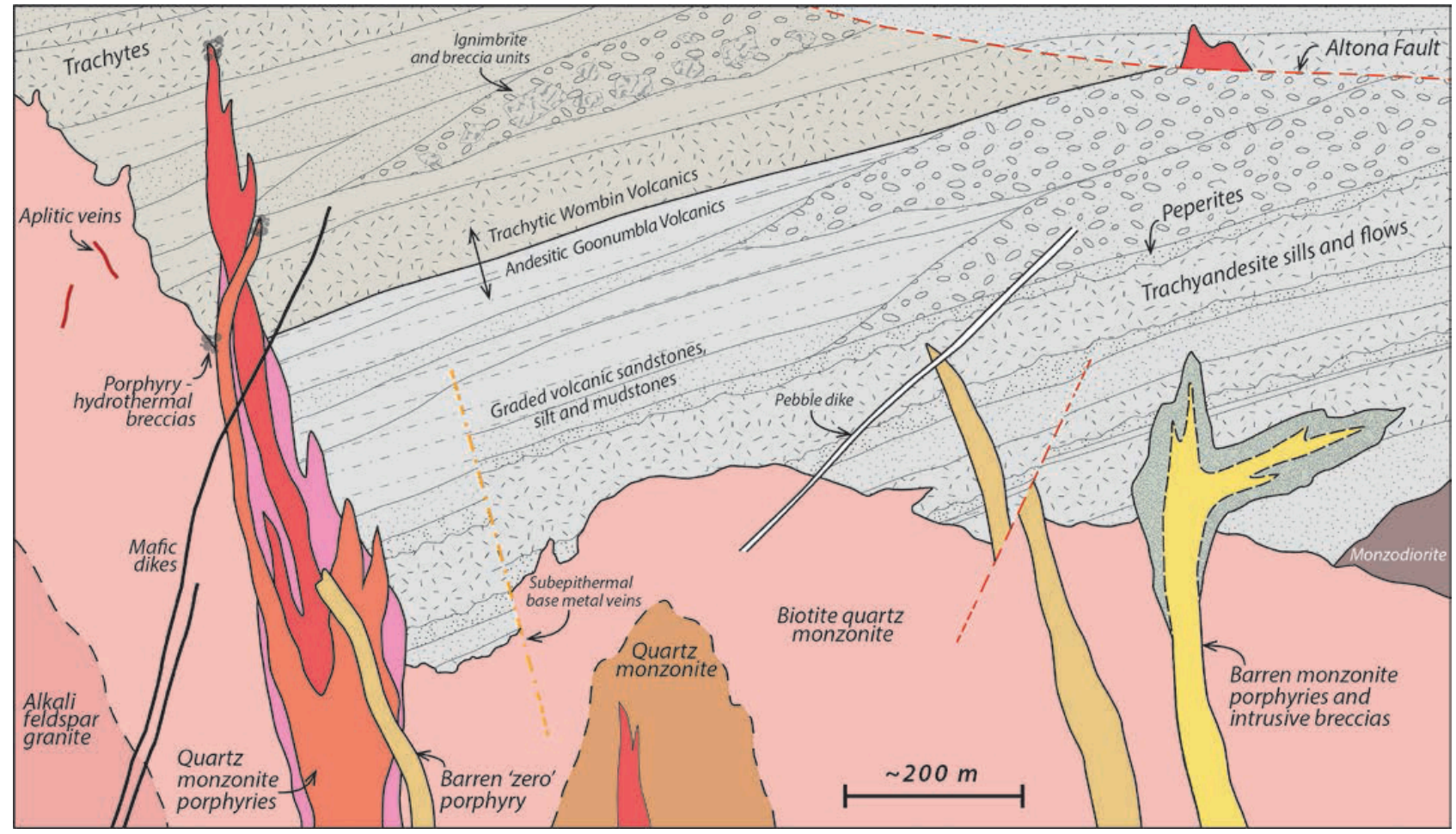


Figure 10
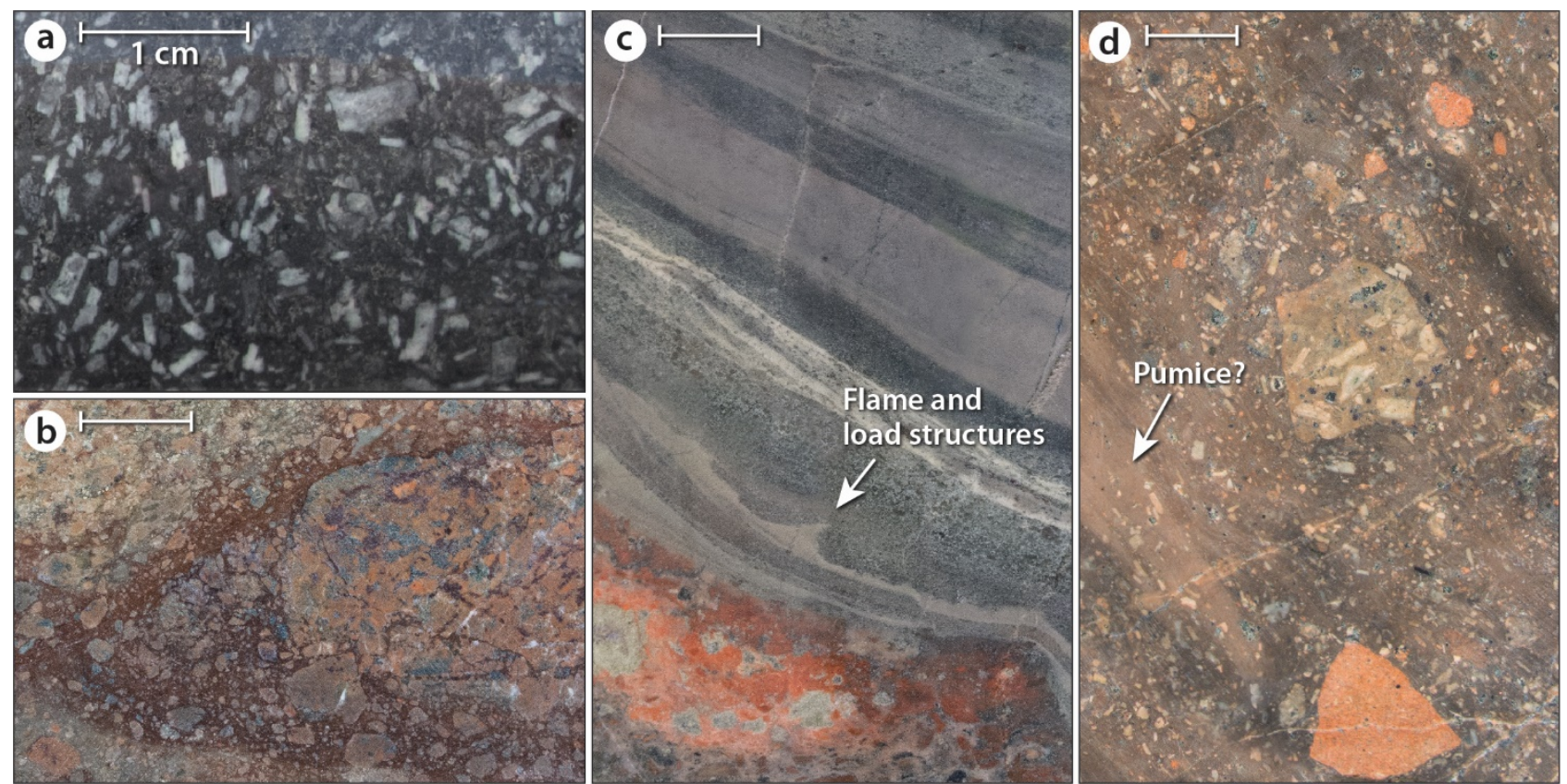

Figure 11
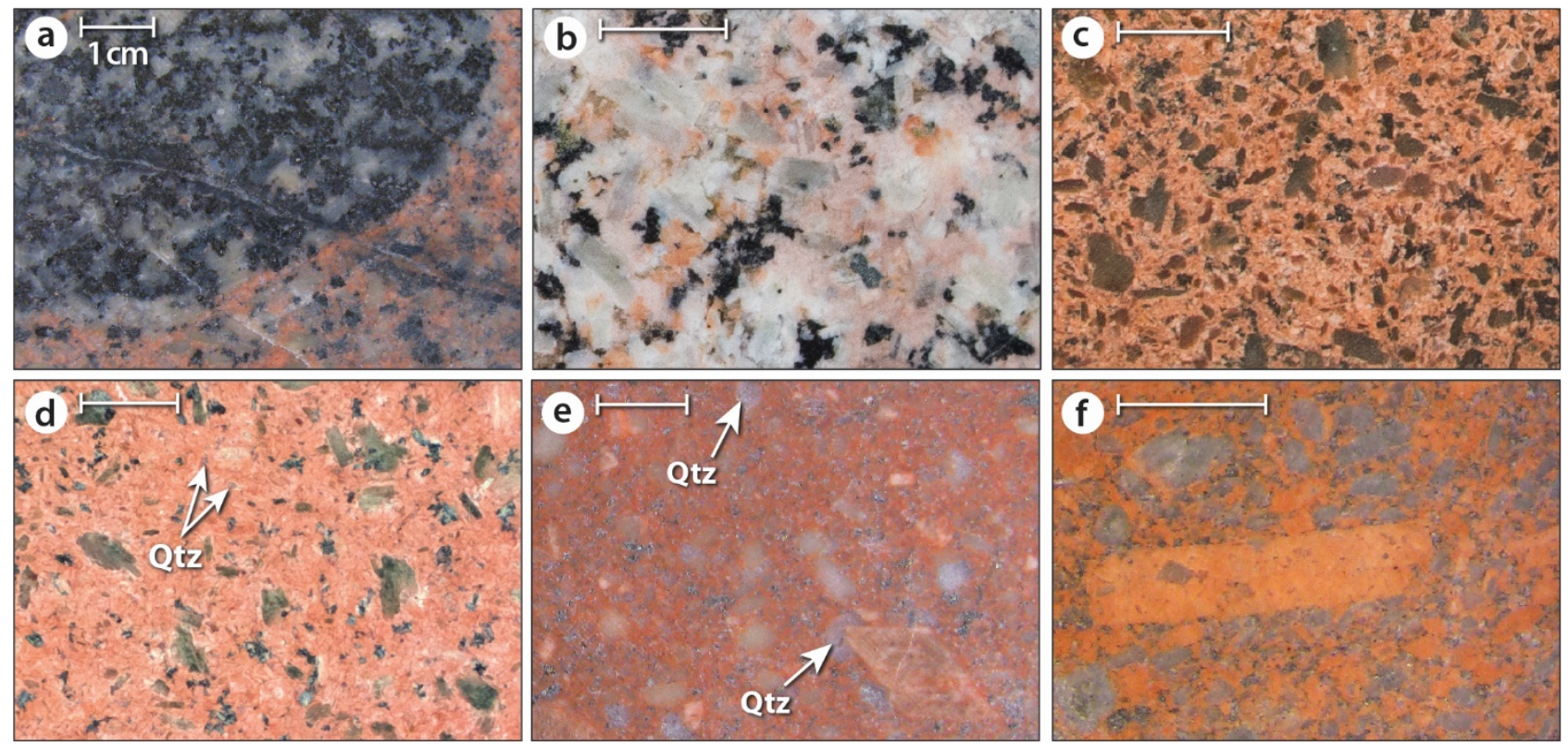
Figure 12

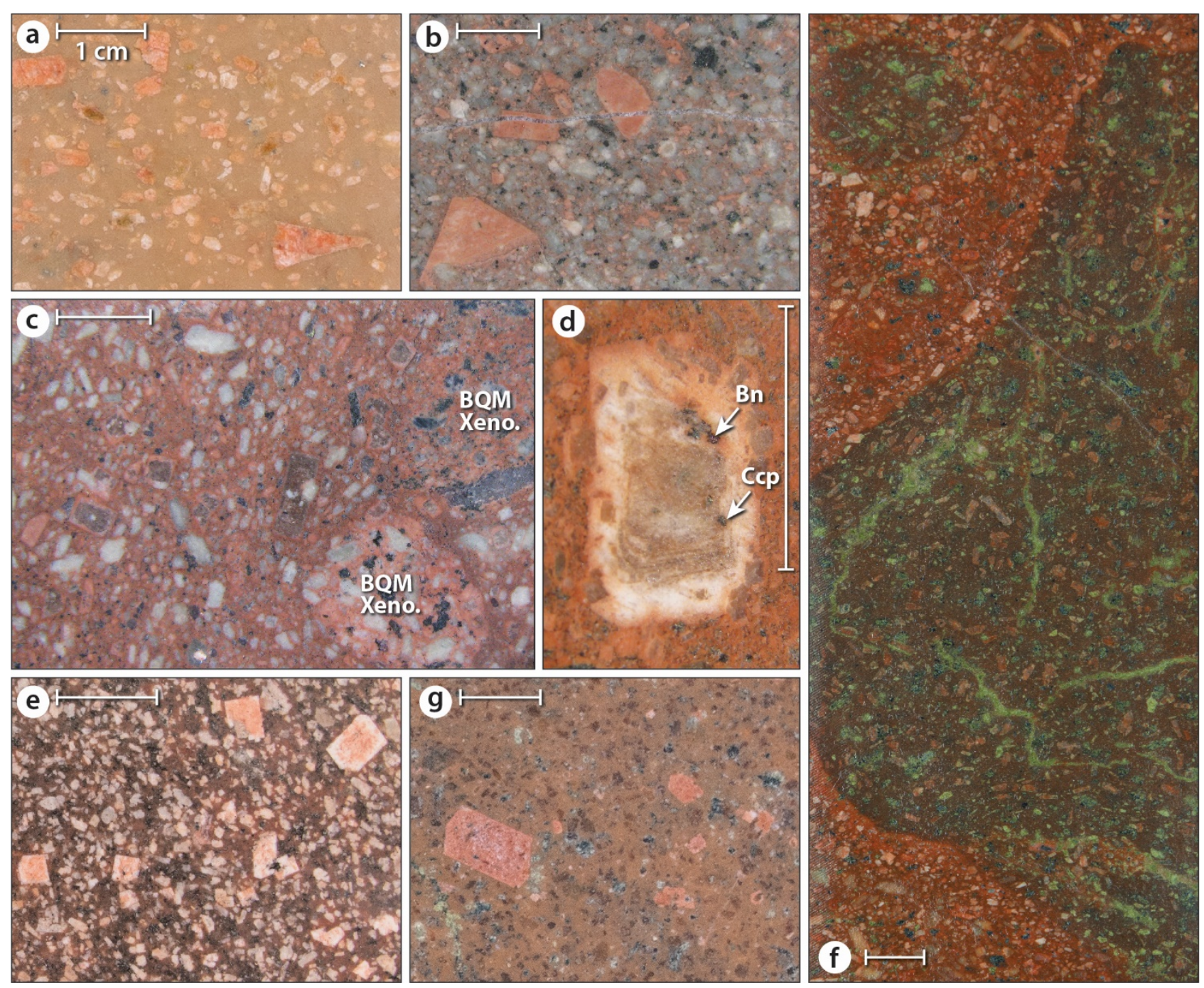




\section{Figure 13}
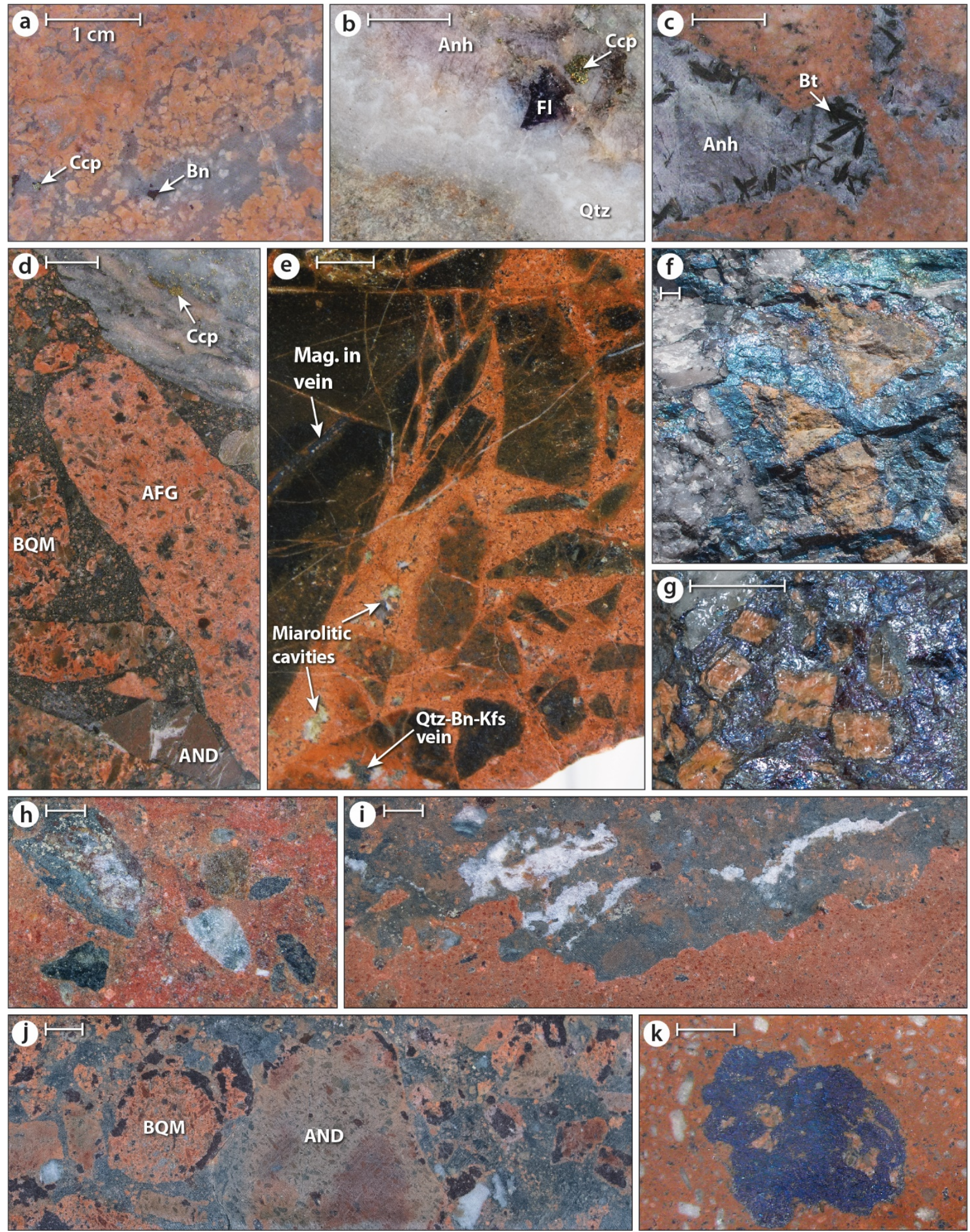
Figure 14

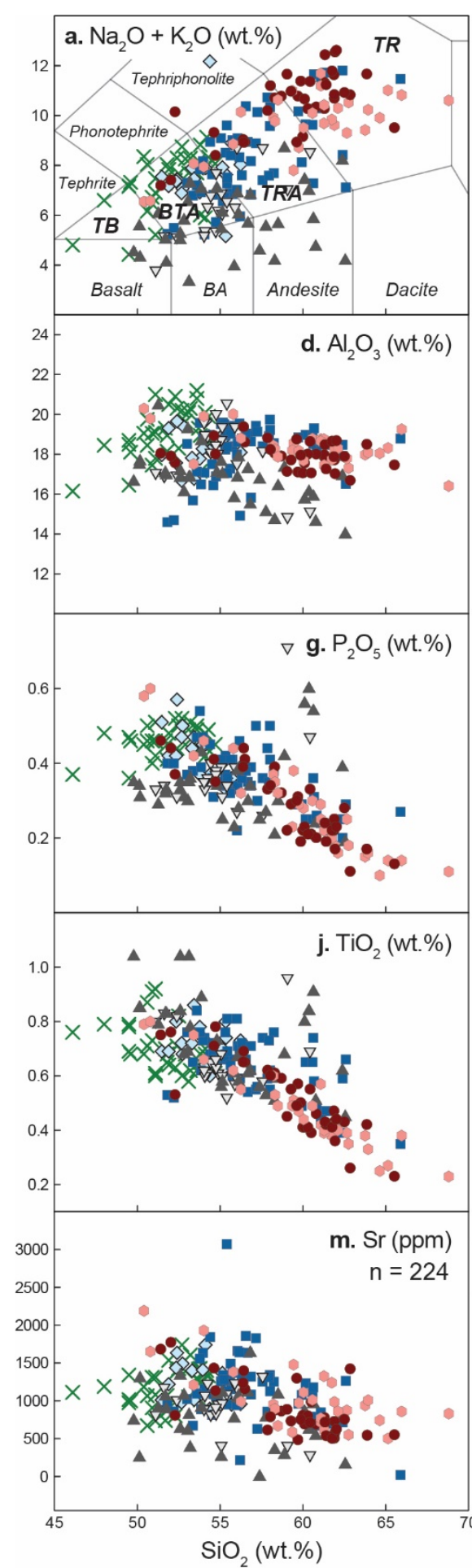

$\mathrm{SiO}_{2}$ (wt.\%)

- Nelungaloo Volcanics

$\nabla$ Nelungaloo Intrusions
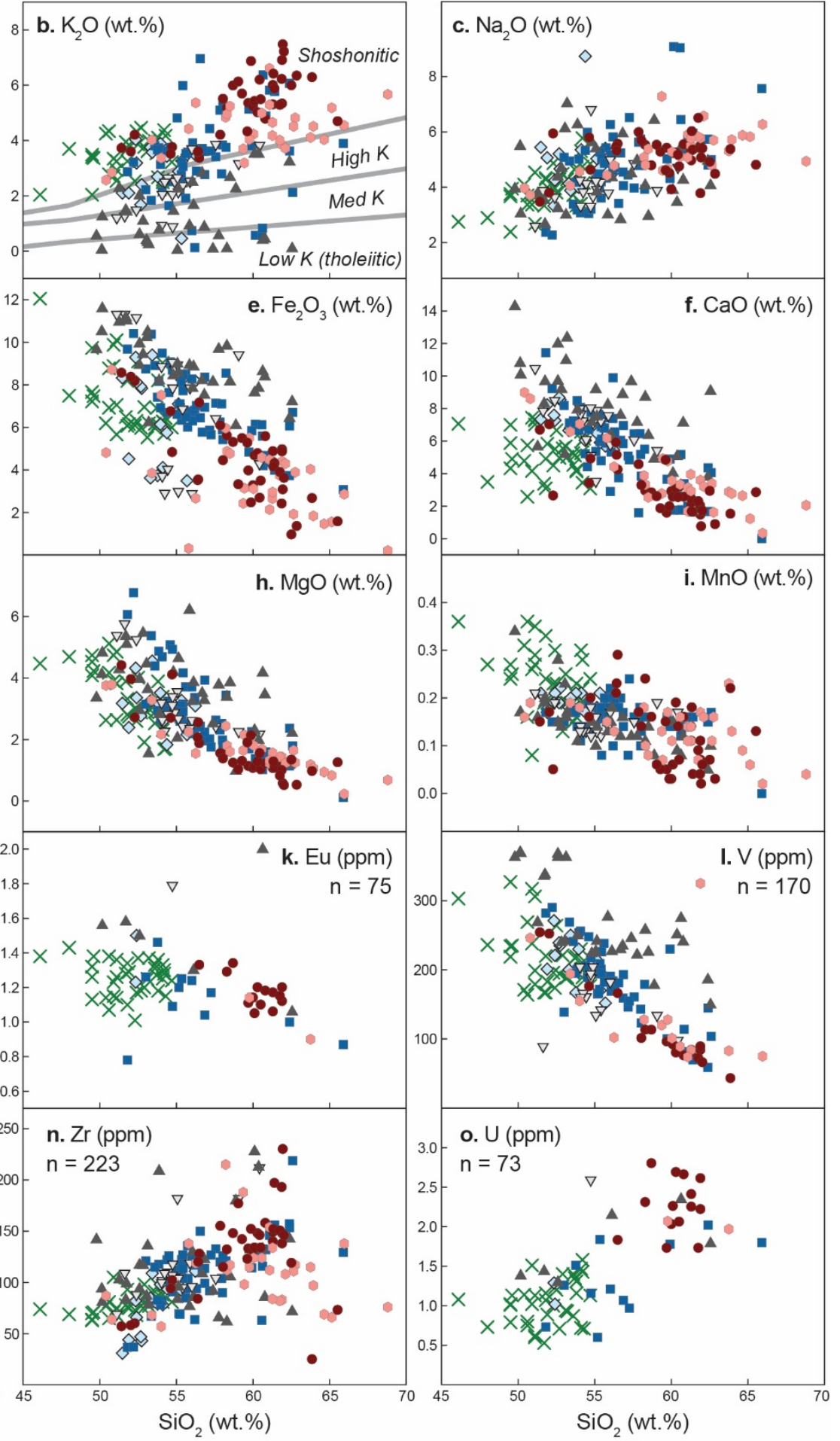

${ }_{0.0}^{0.4}$
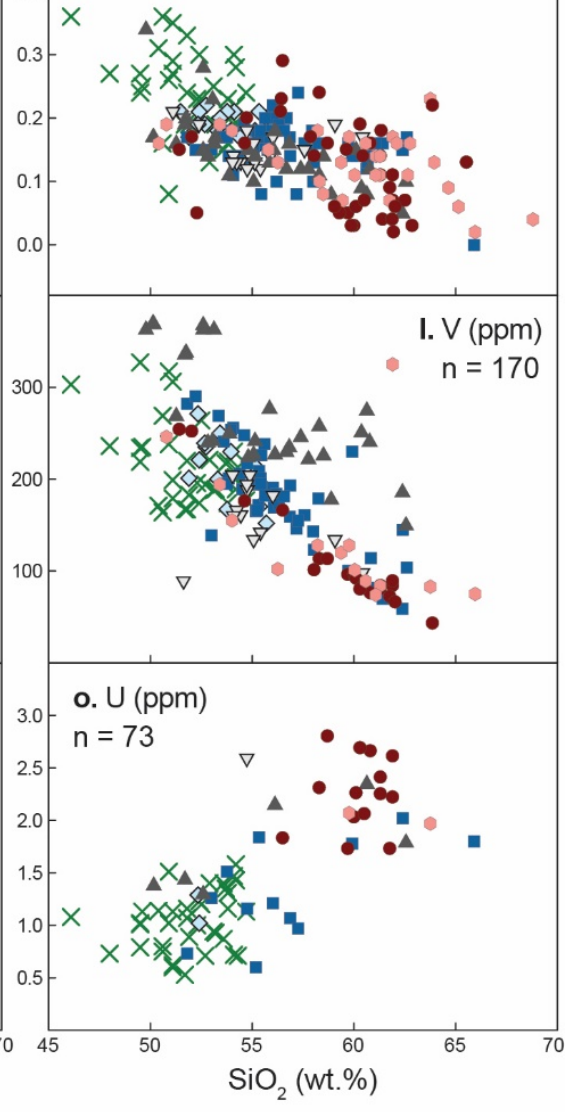

- Goonumbla Volcanics

$\diamond$ Goonumbla Intrusions

- Wombin Volcanics

$\times$ Trachyandesites

- Wombin Intrusions 
Figure 15

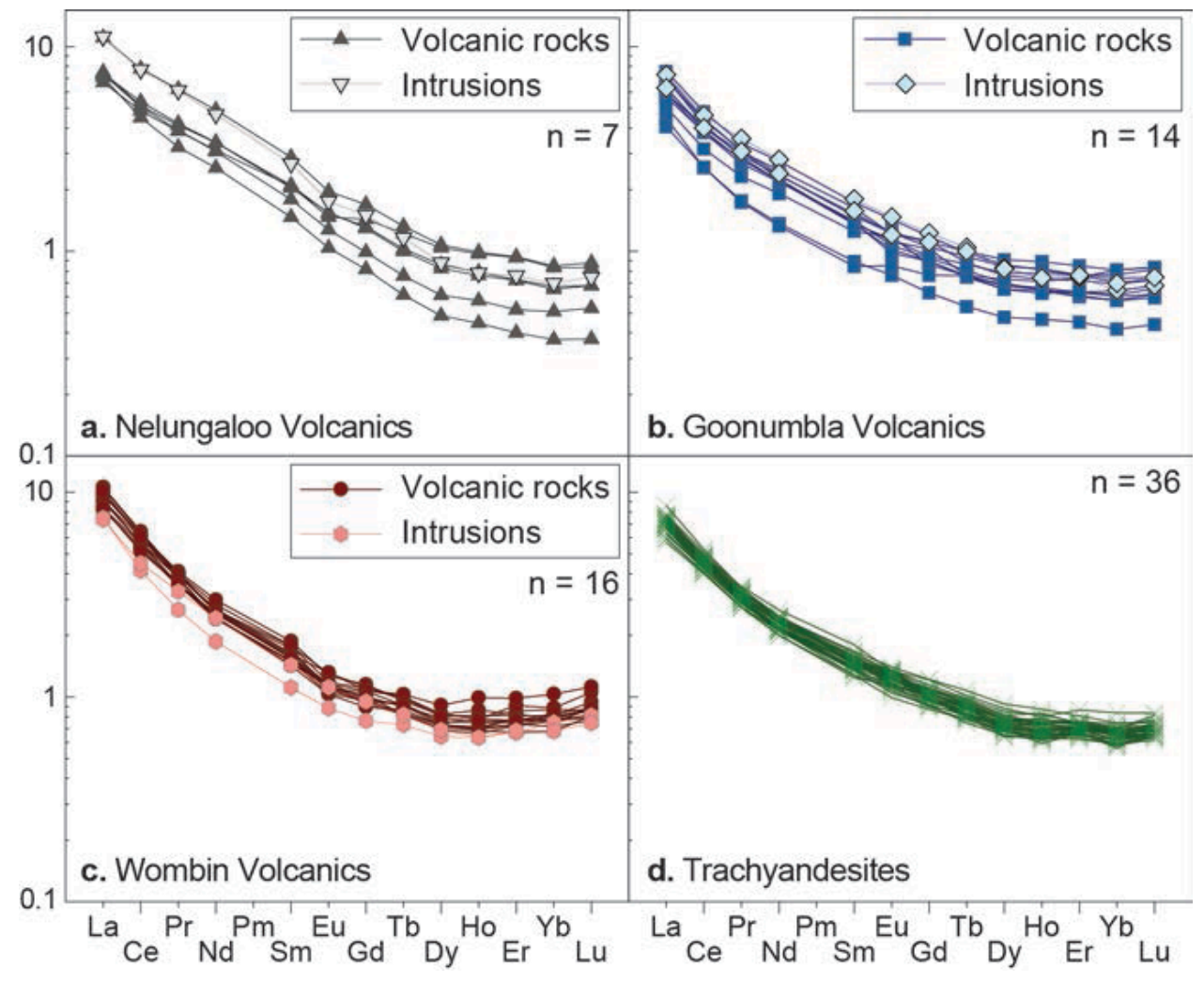


Figure 16
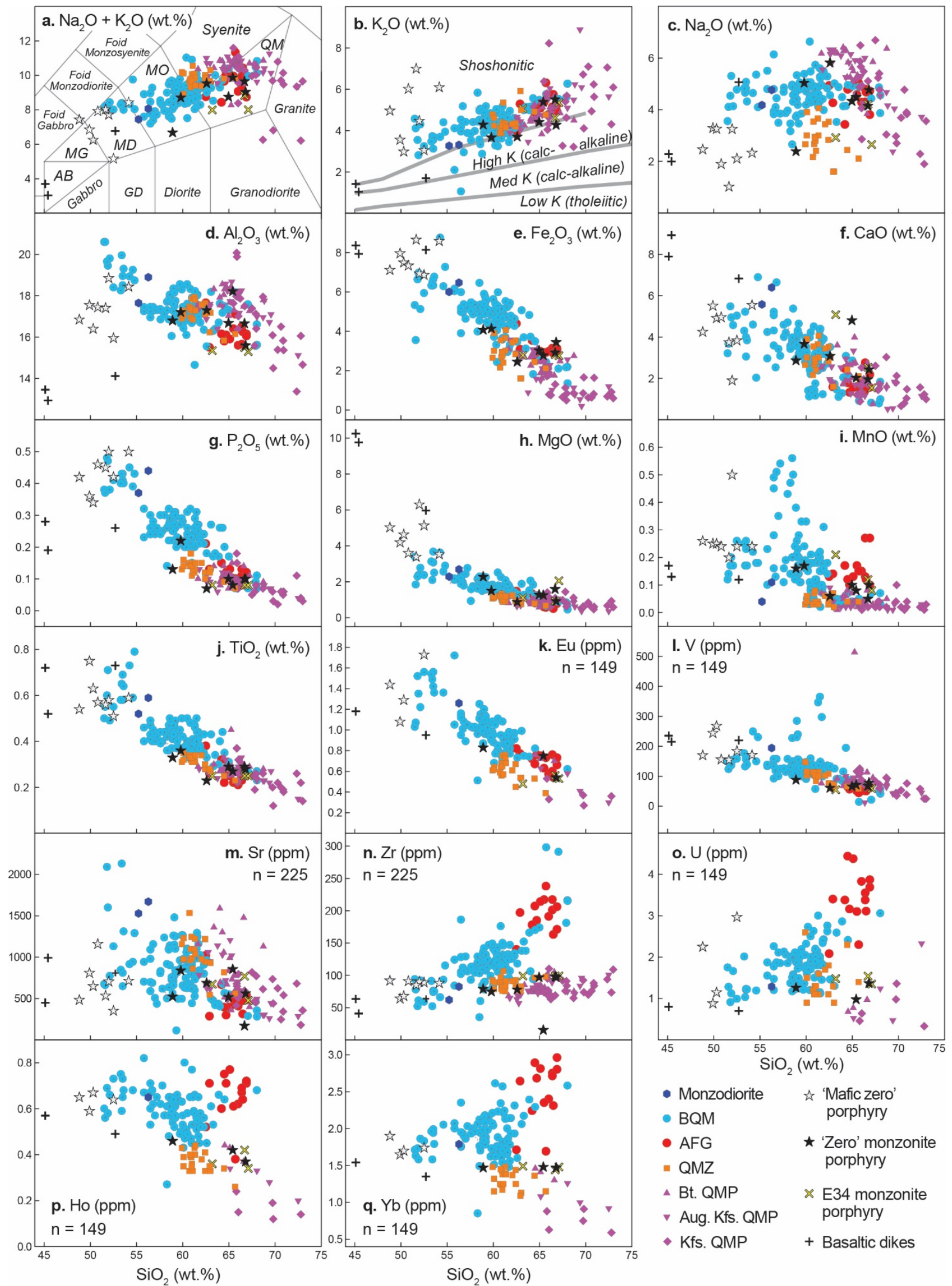

- Monzodiorite is 'Mafic zero'

- BQM

'Zero' monzonite

QMZ

E34 monzonite

q. $\mathrm{Yb}(\mathrm{ppm})$ $\sin \pi * \pi^{*}$

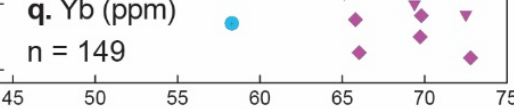
$\mathrm{SiO}_{2}$ (wt.\%) 
Figure 17

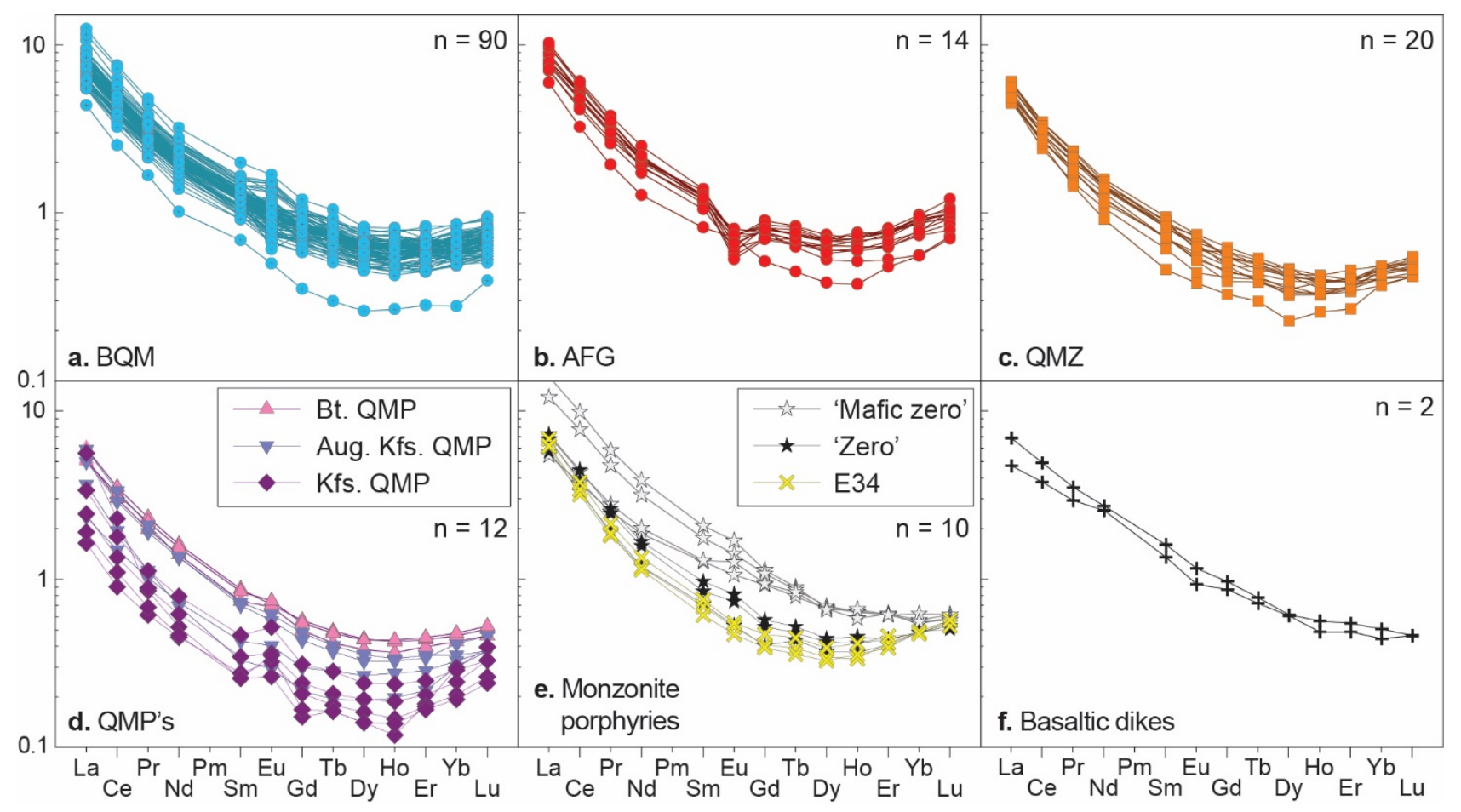


E26D459

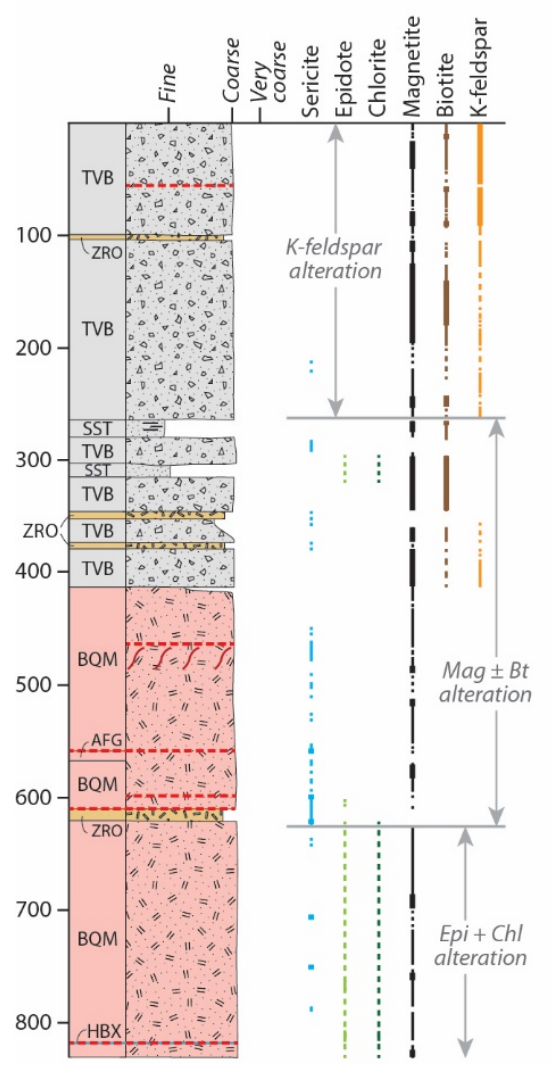

Lithological groups:

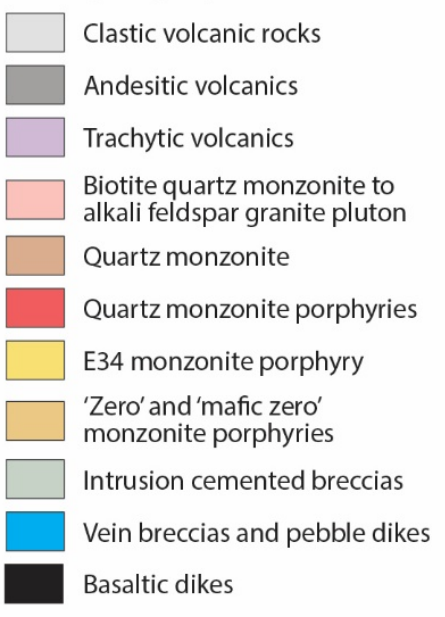

E26D460

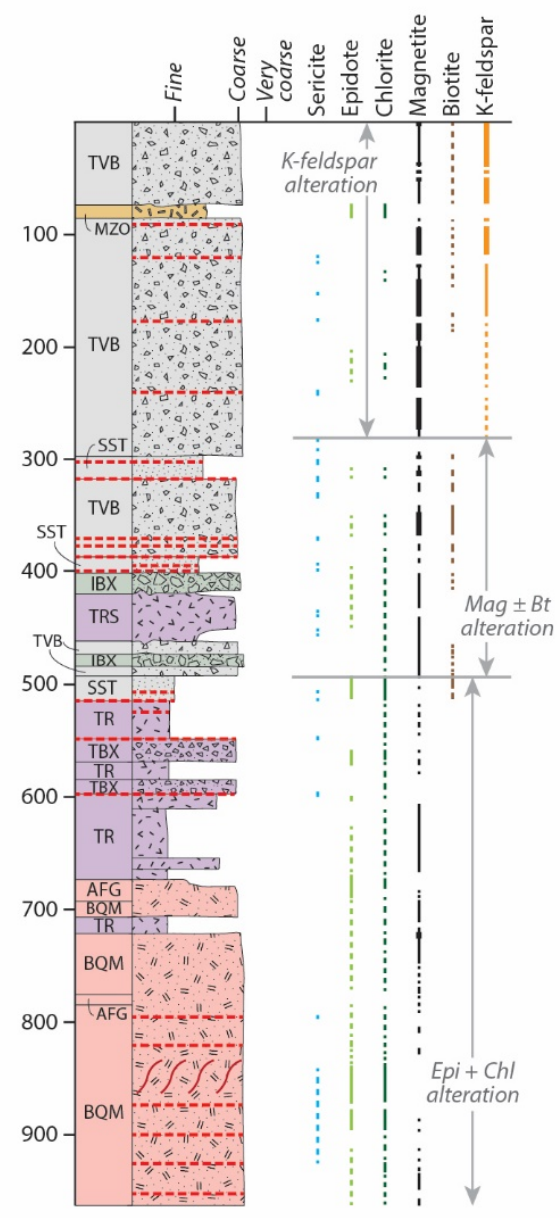

Textures:

\begin{tabular}{|c|c|}
\hline & Fine clastic \\
\hline & $\begin{array}{l}\text { Conglomerates and clastic } \\
\text { breccias, matrix supported }\end{array}$ \\
\hline & $\begin{array}{l}\text { Conglomerates, often } \\
\text { clast supported }\end{array}$ \\
\hline & Porphyritic volcanics \\
\hline & Semi-porphyritic intrusions \\
\hline & Porphyritic intrusions \\
\hline & $\begin{array}{l}\text { Hydrothermal segregations } \\
\text { and mineralized xenolith in QMP }\end{array}$ \\
\hline & Intrusion related brecciation \\
\hline & Breccia, e.g. fault or hyaloclastic \\
\hline
\end{tabular}

E26D507

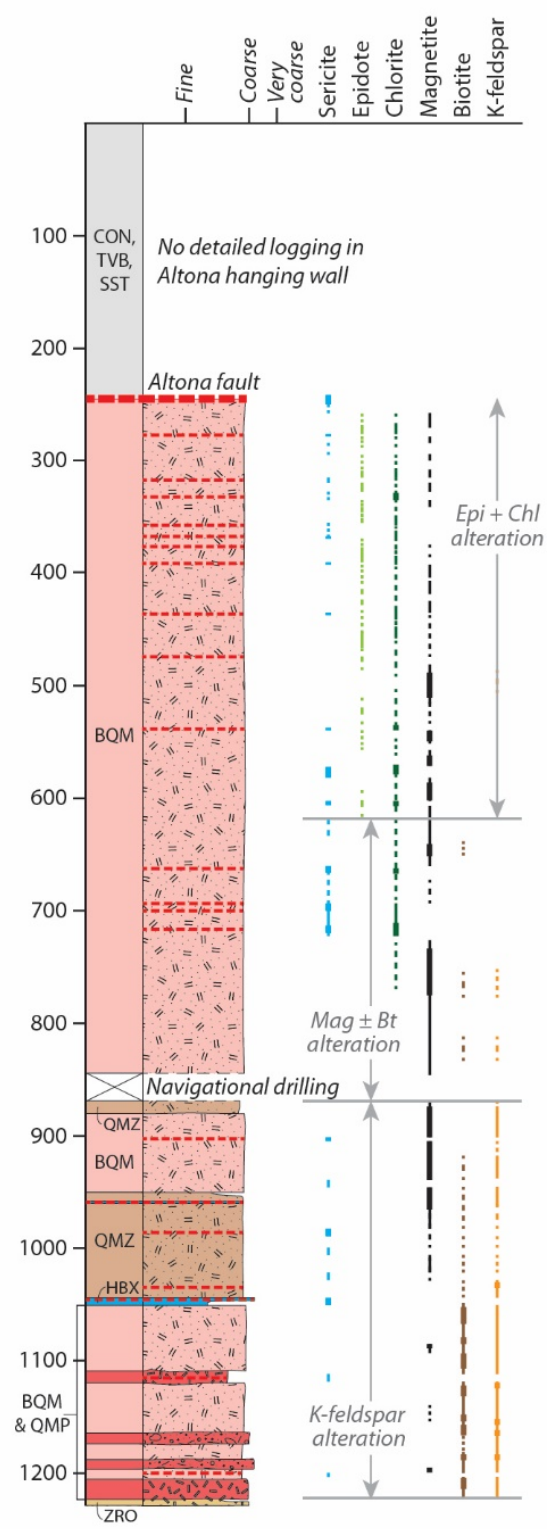

Symbols:

.---. Fault, or faulted contact if full width of column

$\int \mathcal{S}$ Zone of shearing/fracturing

.-^.. Gradational contact over arrowed distance

$=$ Sedimentary laminations

Abundance of alteration minerals: 
E48D134

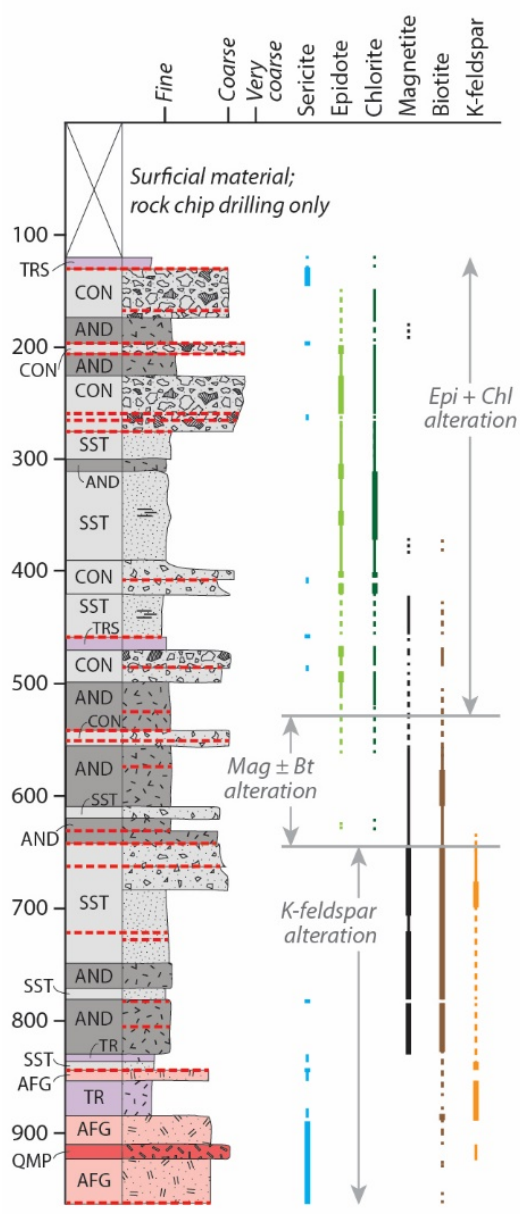

E26D361

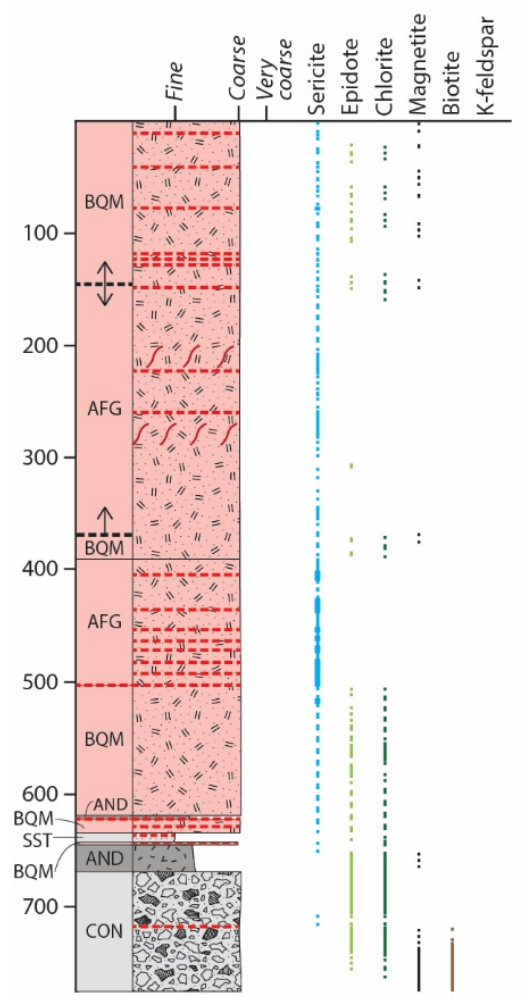

E48D147

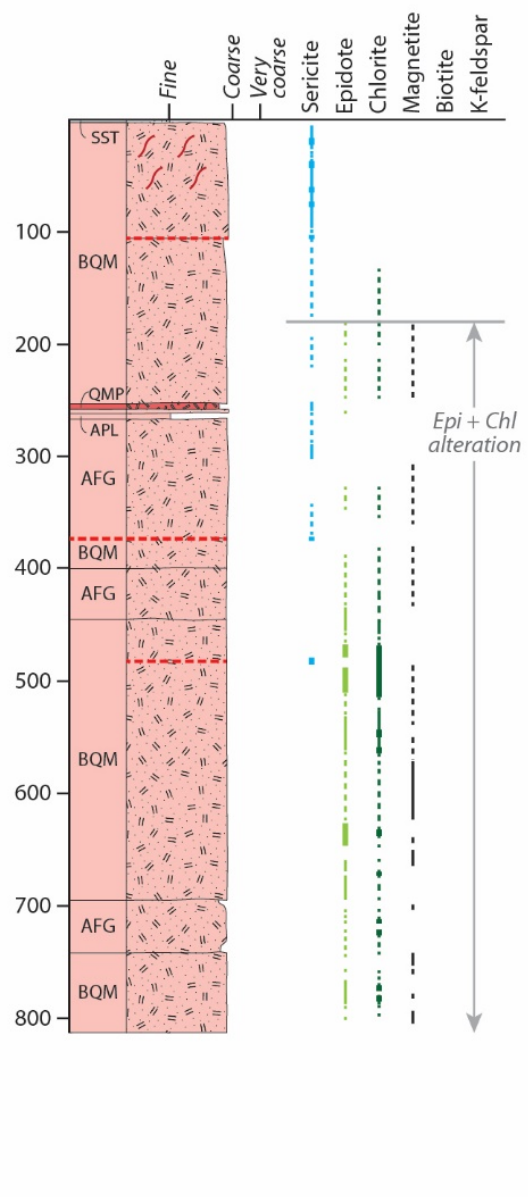

GD654

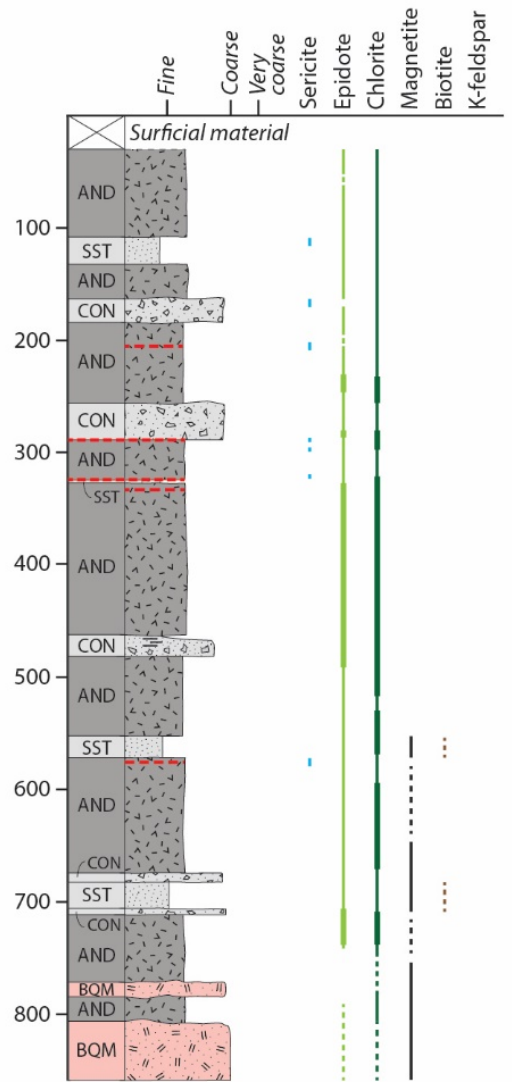

E34D3

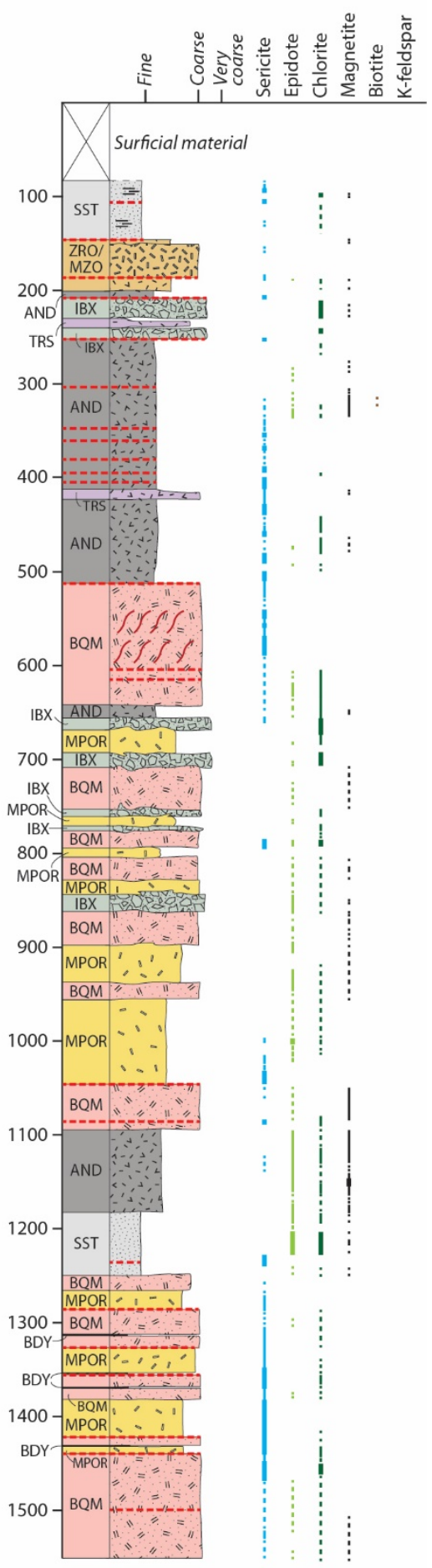


Figure 20

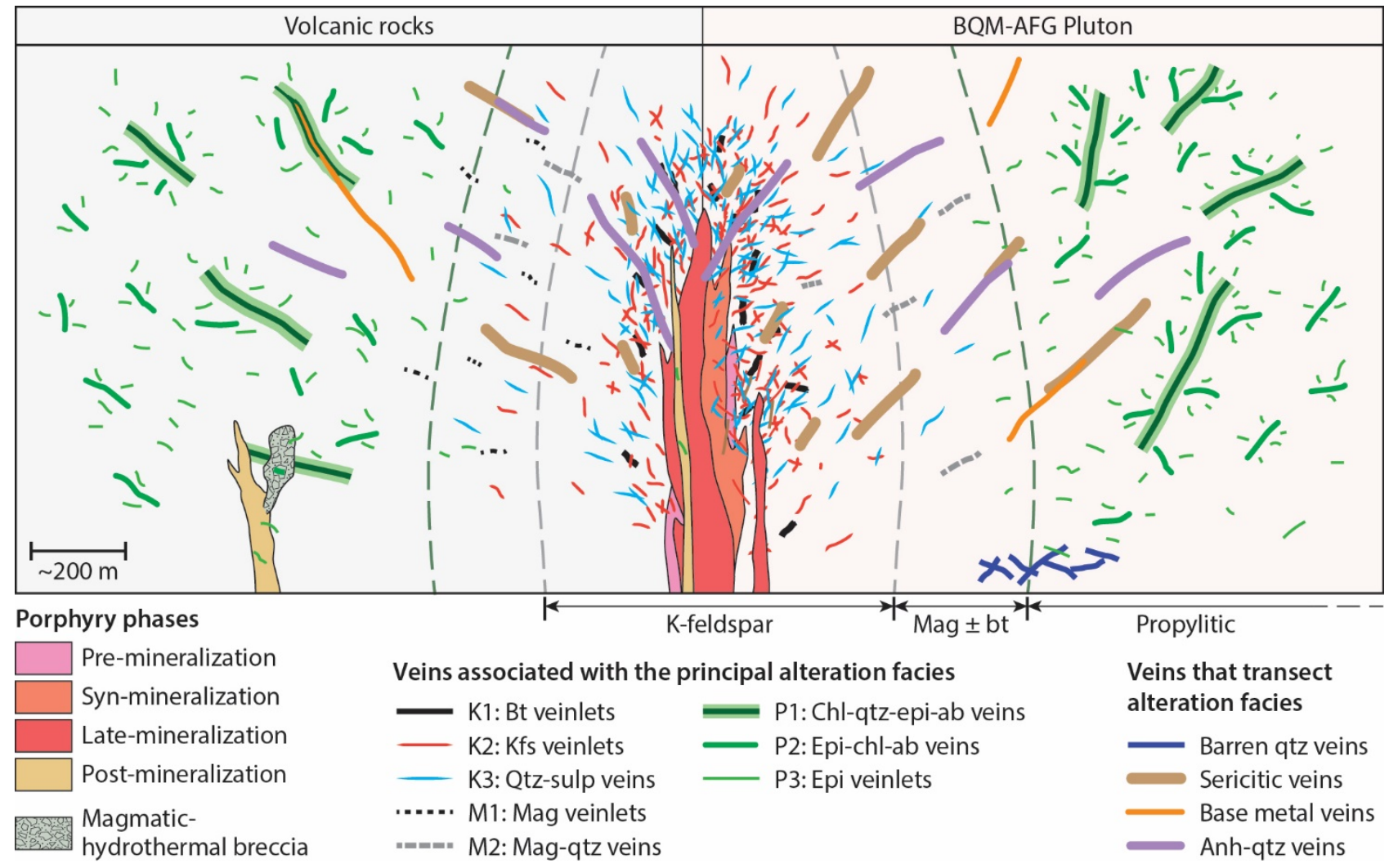


Figure 21
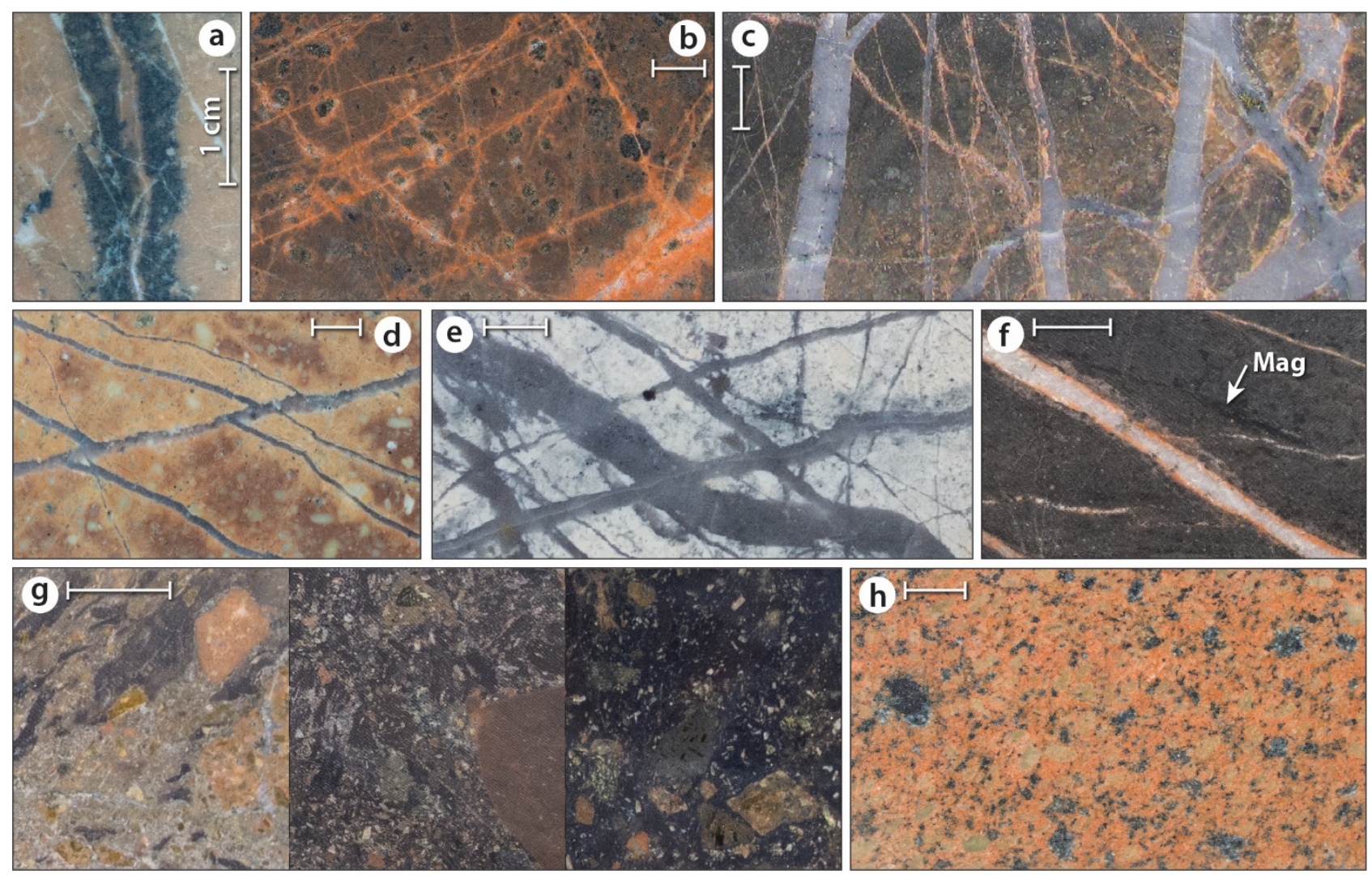
Figure 22
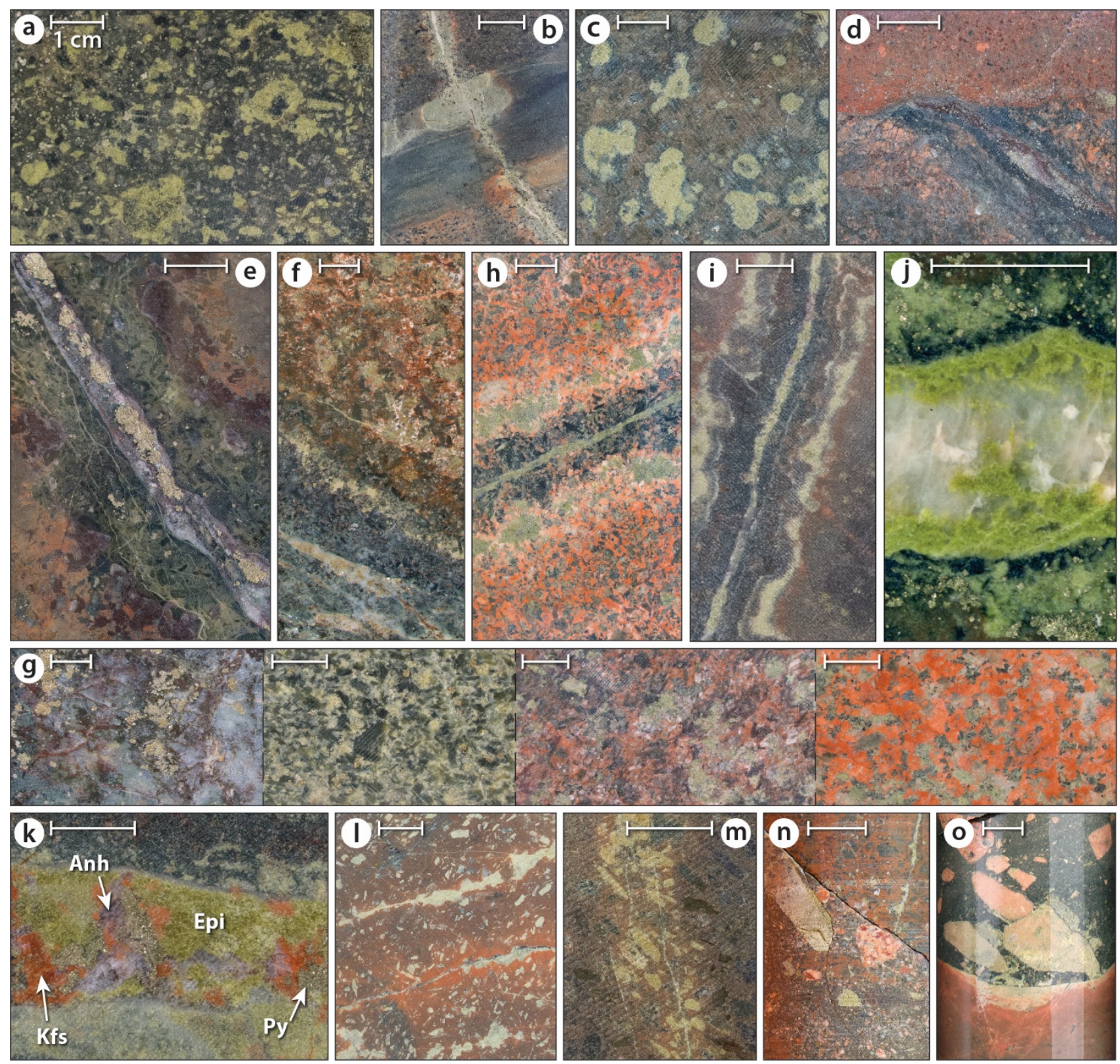


\section{Figure 23}
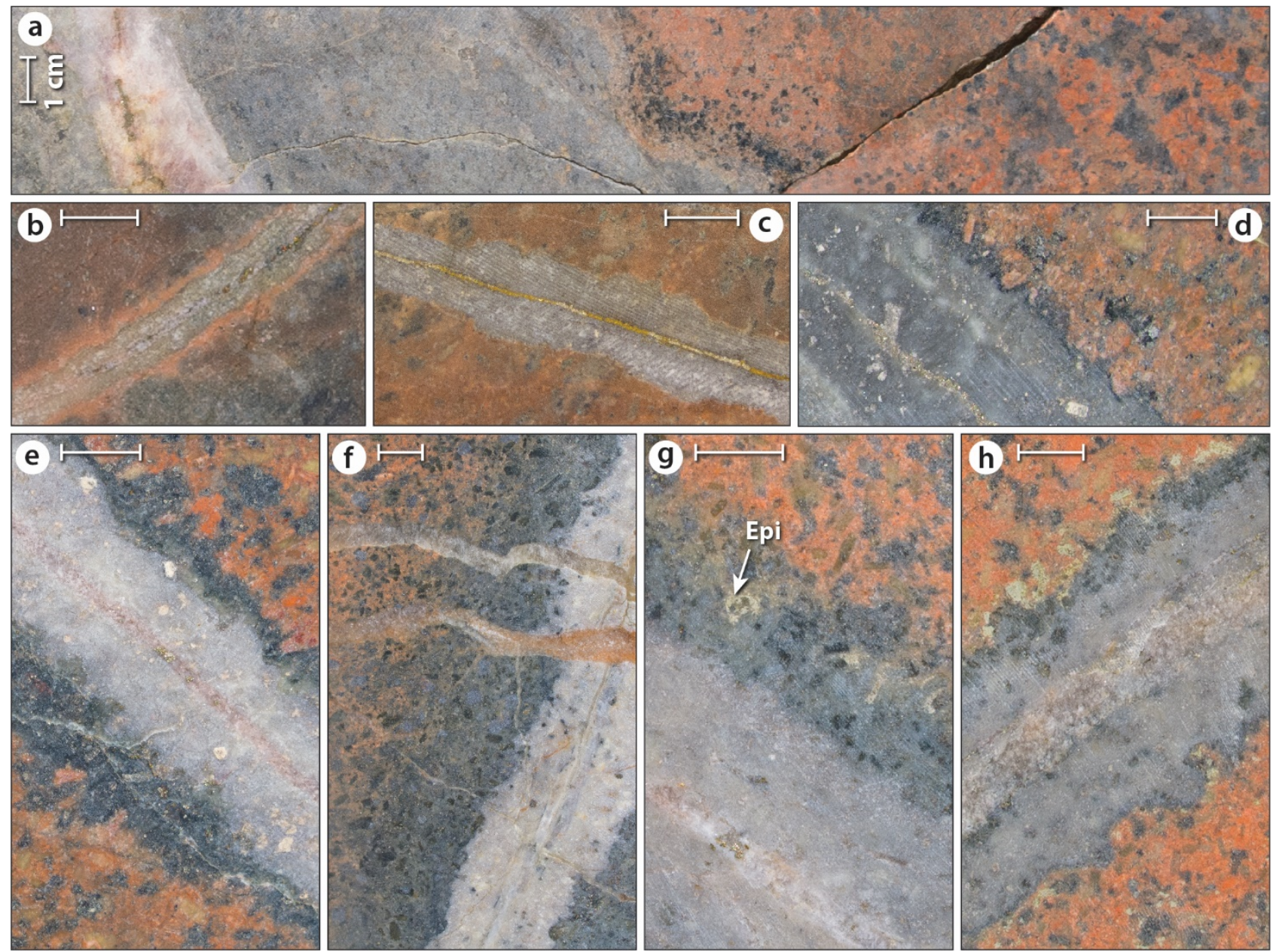

Figure 24
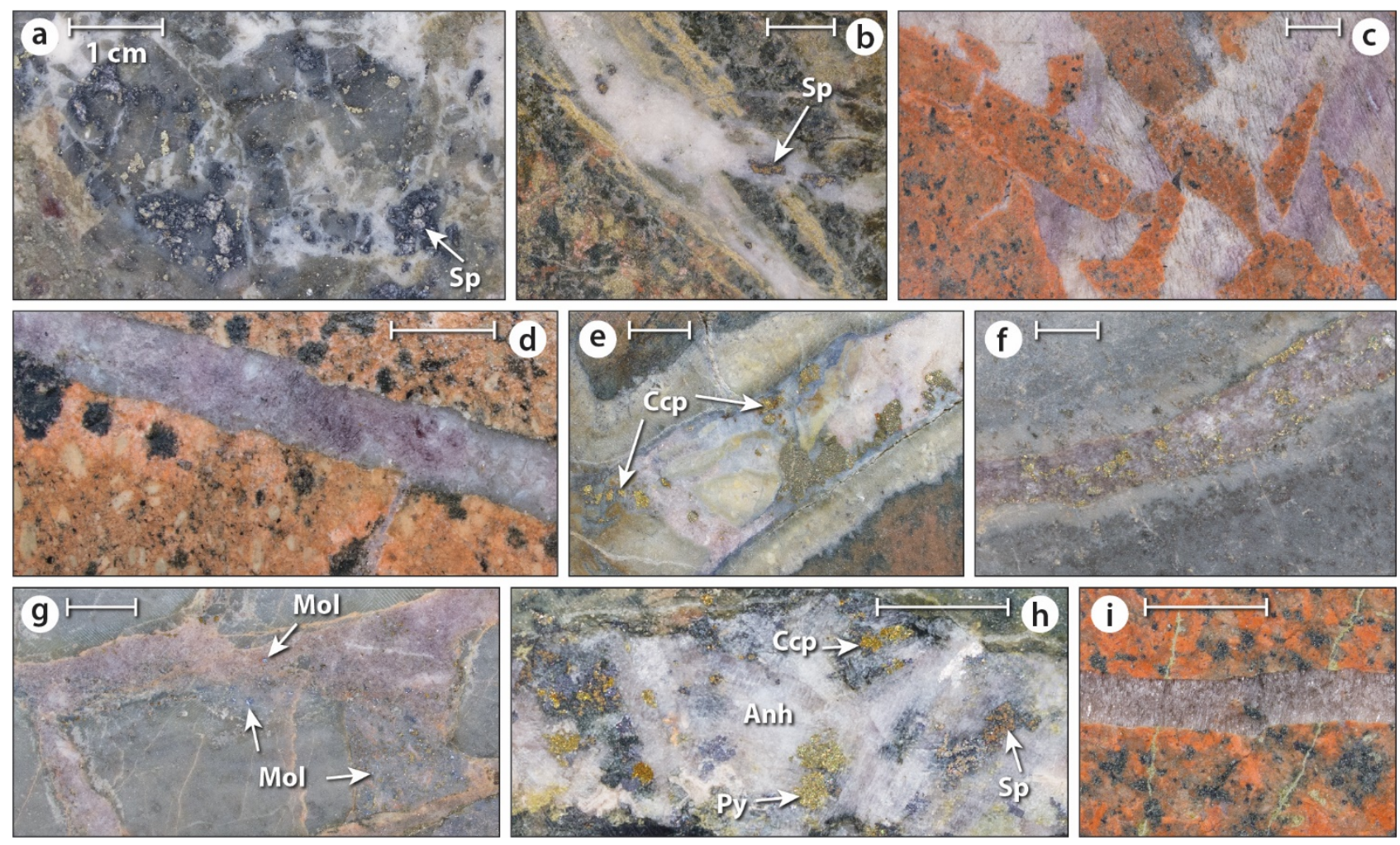